\title{
COMERCIALIZAÇÃO DE FEIJÃO NO BRASIL 1990-99
}

\section{CARLOS MAGRI FERREIRA}

\begin{abstract}
Dissertação apresentada à Escola Superior de Agricultura "Luiz de Queiroz", Universidade de São Paulo, para obtenção do título de Mestre em Ciências, Área de Concentração: Economia Aplicada.
\end{abstract}

PIRACICABA

Estado de São Paulo - Brasil

Junho- 2001 


\title{
COMERCIALIZAÇÃO DE FEIJÃO NO BRASIL 1990-99
}

\author{
CARLOS MAGRI FERREIRA
}

Engenheiro Agrônomo

Orientador: Prof. Dr. GERALDO SANT'ANA DE CAMARGO BARROS

Dissertação apresentada à Escola

Superior de Agricultura "Luiz de Queiroz", Universidade de São Paulo, para obtenção do título de Mestre em Ciências, Área de Concentração: Economia Aplicada.

\author{
PIRACICABA \\ Estado de São Paulo - Brasil \\ Junho - 2001
}


Dados internacionais de catalogação na publicação (CPI) DIVISÃO DE BIBLIOTECA E DOCUMENTAÇÃO - Campus “Luíz de Queiroz”/USP

Ferreira, Carlos Magri

Comercialização de feijão no Brasil 1990-99 / Carlos Magri Ferreira, -- Piracicaba, 2001.

$145 p$.

Dissertação (mestrado) - - Escola Superior de Agricultura Luiz de Queiroz, 2001. Bibliografia.

1. Comercialização agrícola 2. Economia agrícola 3. Feijão 4. Produção agrícola I. Título

CDD33817373

"Permitida a cópia total ou parcial deste documento, desde que citada a fonte - O autor" 
DEDICO à Maria Lúcia, Rafael, Maíra, Milton e Odete. 


\title{
AGRADECIMENTOS
}

\begin{abstract}
A retrospectiva de elaboração desta dissertação me indicou várias pessoas que de alguma forma influenciaram ou me ajudaram. O número foi tão grande que passei vários dias tentando fazer um agradecimento a todos. Então, percebi que estava procurando dizer o que Milton Nascimento já havia escrito em uma de suas canções:
\end{abstract}

"amigo a gente guarda do lado esquerdo do peito" 


\section{SUMÁRIO}

Página

LISTA DE FIGURAS …............................................................................ viii

LISTA DE TABELAS ................................................................................

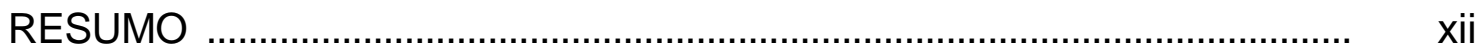

SUMMARY........................................................................................ xiv

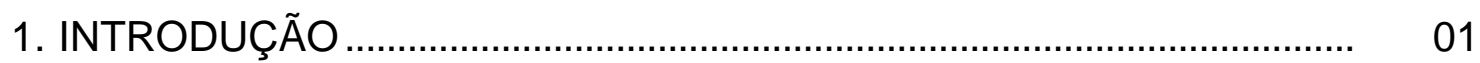

1.1 Um breve histórico da comercialização, produção e do consumo de feijão no Brasil...................................................................................... 03

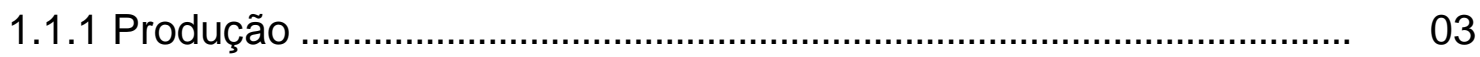

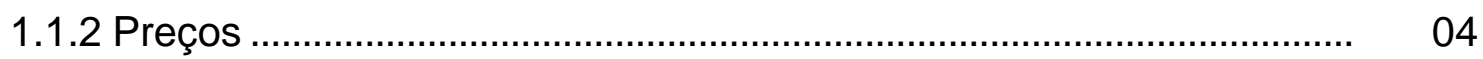

1.1.3 Abrangência geográfica e temporal da produção de feijão no Brasil $\quad 07$

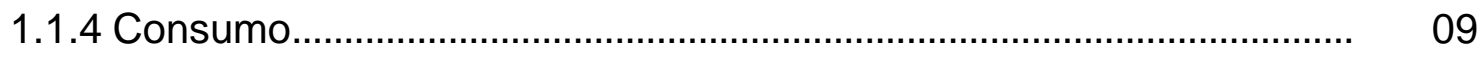

1.1.5 Resenha dos principais acontecimentos relacionados com o mercado de feijão na década de 1990 .............................................. 10

1.2 Identificação, caracterização e importância do problema ....................... 18

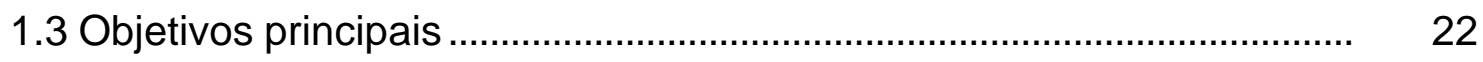

1.3.1 Geral .............................................................................. 22

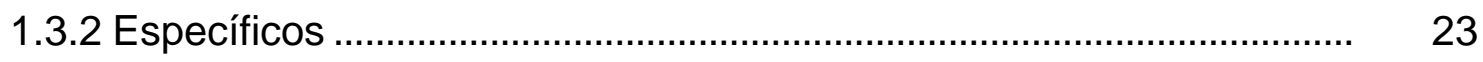

1.4. Delineamento do trabalho ……………………….......................... 23

2 REVISÃO DE LITERATURA ....................................................................... 25

2.1 Resultados de outras pesquisas ……….............................................. 25

2.1.1 Canais de comercialização ................................................................. 25 
2.1.2 Margens de comercialização .............................................................. 27

2.1.3 Causalidade e transmissão de preços ................................................. 31

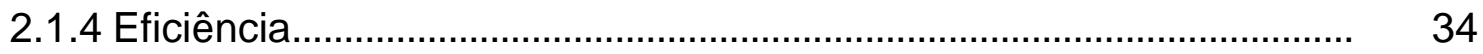

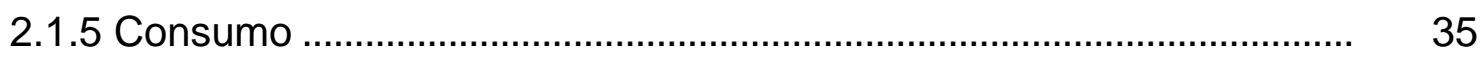

2.1.6 Projeção de consumo ………………………………………........ 39

2.2 Enfoque e metodologia utilizada nos estudos e relacionamento entre estes e o presente trabalho ............................................................ 41

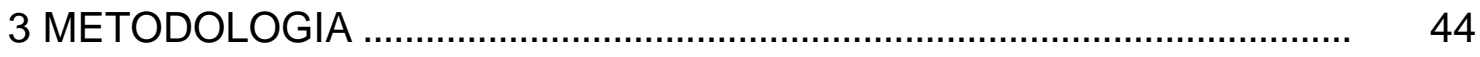

3.1 Levantamento e tratamento dos dados ................................................. 44

3.2 Estudo das margens de comercialização ……………………………..... 47

3.3 Estudos econométricos ................................................................... 49

3.3.1 Determinação do número de defasagens .......................................... 50

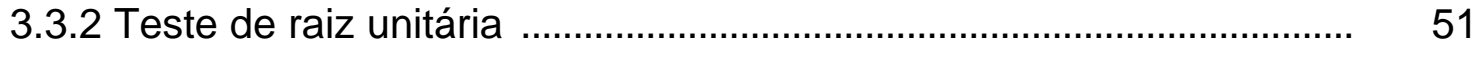

3.3.3 Teste de co-integração ..................................................................... 55

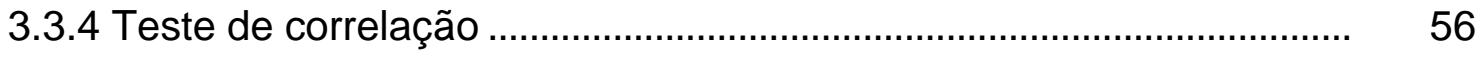

3.3.5 Teste de causalidade .................................................................... 57

3.4 Estimativa da elasticidade de transmissão de preços .............................. 59

3.4.1 Modelo econômico ……………………………………………....... 62

3.4.1.1 Modelo de Barros (1990) ………………........................................... 64

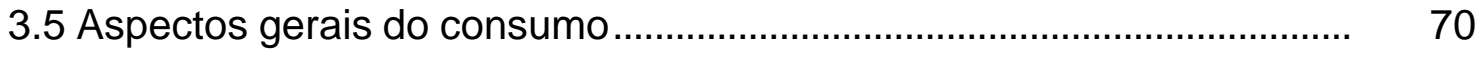

3.6 Projeção do consumo ........................................................................ 71

4 ANÁLISE DOS RESULTADOS ………..................................................... 
4.1 Abrangência geográfica e temporal da produção, importação e principais fluxos de comercialização de feijão no Brasil................................................

4.2 Preços mensais recebidos pelos produtores nos principais Estados produtores de feijão no Brasil e preços nos mercados atacadista e varejista da cidade de São Paulo

4.3 Considerações sobre fluxo

4.4 Estudo das margens de comercialização.

4.5 Estudo econométrico

4.6 Estudo da transmissão de preços.

102

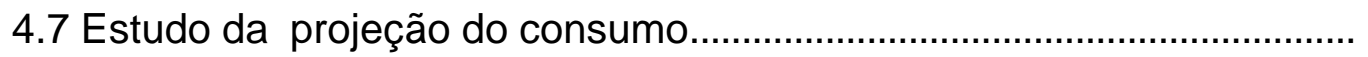

109

5 CONCLUSÕES

REFERÊNCIAS BIBLIOGRÁFICAS.

116

APÊNDICE

122 


\section{LISTA DE FIGURAS}

1 Produção média anual de feijão no Brasil, no período 1990-99 (em 1000 t)

Página

2 Preços da tonelada de feijão no Estado de São Paulo, no período de 1960 a 1970. Valores deflacionados pelo índice geral de preços, da Fundação Getúlio Vargas - 1969.

04

06

3 Preço médio mensal recebido pelos produtores de feijão (saco 60 quilos), no período de 1985 a 1999. Valores em Real

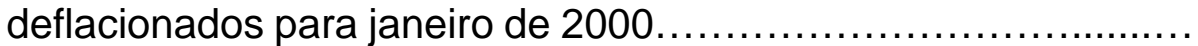

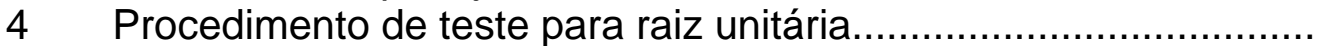

$5 \quad$ Esquema geral dos testes econométricos...................................

6 Média percentual mensal em relação ao total colhido, período de 1990-99.

7 Fluxos mensais de colheitas nos Estados que influenciam o mercado atacadista de São Paulo.

8 Comportamento e tendências linear e polinomial dos preços médios recebidos pelos produtores do Rio Grande do Sul, no período de 1990-99.

9 Comportamento e tendências linear e polinomial dos preços médios recebidos pelos produtores da Bahia, no período de 1990-99.

10 Comportamento e tendências linear e polinomial dos preços médios recebidos pelos produtores de Minas Gerais, no período de 1990-99.

11 Comportamento e tendências linear e polinomial dos preços médios recebidos pelos produtores de São Paulo, no período de 1990-99

12 Comportamento e tendências linear e polinomial dos preços médios recebidos pelos produtores do Paraná, no período de 1990-99.

13 Comportamento e tendências linear e polinomial dos preços médios recebidos pelos produtores de Santa Catarina, no período de 1990-99.

14 Comportamento e tendências linear e polinomial dos preços médios recebidos pelos produtores de Goiás, no período de 1990-99 
15 Relações de causalidade entre os preços recebidos pelos produtores dos Estados produtores............................................

16 Relações de causalidade entre os Estados e os mercados atacadista e varejista de São Paulo.

17 Consumo per capita aparente anual de feijão no Brasil, período de 1990-99. 


\section{LISTA DE TABELAS}

Página

1 Área (1000 hectares), produção (1000 toneladas) e rendimento (kg/ha) do feijão no Brasil no período de 1960 a 1999.

2 Distribuição das épocas de colheita das grandes safras de feijão nos principais Estados produtores e no Nordeste do Brasil......................................................................................

3 Consumo per capita aparente de feijão no Brasil kg/habitante/ano...

4 Margem percentual mensal e anual do varejo.

08

09

29

$5 \quad$ Margem anual percentual do atacado, no período de $1976-84 \ldots \ldots . . . .$.

6 Transmissão de preços entre o mercado atacadista e varejista de São Paulo.

7 Transmissão de preços entre preços em diferentes níveis de mercado...

32

33

8 Transmissão de preços entre preços em diferentes níveis de mercado.

9 Consumo estimado total (1000 toneladas) de feijão e per capita (kg/hab/ano) de 1974/75.

10 Taxas de crescimento do suprimento, consumo de feijão e da população do Brasil nas décadas de 60,70, 80 e 90.

11 Dados estimados e projeção sobre consumo total (1000 toneladas) e per capita (kg/habitante/ano) de feijão de 1978 a 1981

12 Projeção do consumo interno per capita ( $\mathrm{kg} / \mathrm{habitante} / \mathrm{ano}$ ) e consumo total aparente (1000 toneladas) de feijão no período de 1992 a 1995.

13 Produção total anual de feijão no Brasil, nos principais Estados produtores e nas demais regiões, no período de 1990-99 (1000 /toneladas)

14 Relação entre as produções dos Estados.

15 Percentual médio anual e mensal do índice de colheita nas Regiões Norte, Nordeste, outros Estados da Região Centro Sul e nos principais Estados produtores de feijão, no período de 1990 a 1999.

16 Quantidades (1000 toneladas), de feijão importado e percentual em relação à produção interna, no período de 1960 a 1999

17 Preços médios recebidos pelos produtores dos estados, no atacado e varejo de São Paulo. Valores em Real, deflacionados para janeiro de 2000 
18 Preços médios mensais recebidos pelos produtores dos Estados produtores, preços no atacado e varejo de São Paulo. Período de 1990-99 (saco de 60 quilos de feijão, valores deflacionados para janeiro de 2000).

19 Margem de comercialização absoluta (em Reais, valores deflacionados para janeiro de 2000) e relativa do atacado

20 Margem de comercialização total (em Reais, valores deflacionados para janeiro de 2000) e total relativa.

21 Margem de comercialização absoluta (em Reais, valores deflacionados para janeiro de 2000) e relativa do varejo.

22 Médias mensais das margens de comercialização de feijão total e absoluta (valores deflacionados para janeiro de 2000) e relativa do atacado, do varejo e total. Saco de 60 quilos

23 Equação de transmissão de preços de feijão Atacado/varejo

24 Estimativa das elasticidades de transmissão de preços parciais e totais - Atacado/varejo, período 1990-99

25 Equação de transmissão de preços de feijão - Atacado produtor.

26 Estimativa das elasticidades de transmissão de preços parciais e totais - Atacado/produtor, período 1990-99.

27 Elasticidade de transmissão de preços pago aos produtores dos principais estados produtores de feijão no Brasil, no período de 1990-99

28 Projeção da demanda de feijão no período de 2000 a 2005 


\title{
COMERCIALIZAÇÃO DE FEIJÃO NO BRASIL 1990-99
}

\author{
Autor: CARLOS MAGRI FERREIRA \\ Orientador: Prof. Dr. GERALDO SANT'ANA DE CAMARGO BARROS
}

\section{RESUMO}

O objetivo do trabalho foi estudar a produção e comercialização de feijão no Brasil na década de 1990, tendo como referencial o Plano Real e fazer uma projeção de demanda até 2005. Foram realizados estudos sobre a produção, considerando épocas de colheita, distribuição geográfica, principais fluxos de distribuição. Foram também estimadas relações entre preços recebidos pelos produtores dos sete principais estados produtores e entre preços ao atacado e varejo na cidade de São Paulo. Foram estimadas as margens de comercialização e realizados estudos econométricos, cuja metodologia básica aplicada consistiu de duas etapas, a primeira, foi identificar o sentido da causalidade, ou seja, diante de algum fator ou choque, em que nível de mercado mais freqüentemente se iniciam as alterações de preços, e como essas alterações são transmitidas, ou em que intensidade os níveis de mercado reagem frente aos choques de preços, que podem ter origem na variação da demanda, da oferta de matéria-prima ou da oferta de insumos de comercialização. Por fim, foi feita uma projeção de consumo. 
Os resultados revelam que após o Plano Real ocorreram algumas alternâncias de produção entre as regiões e um crescimento da produção na Região Nordeste. Porém, não ocorreram alterações significativas nas quantidades produzidas de feijão nos tradicionais Estados produtores. Por outro lado, aumentou a quantidade importada. Quanto à concentração da produção, verificou-se a existência de microrregiões cujas produções tem maiores participações e são mais constantes no contexto nacional. Observouse que muitas análises de mercado feitas no período considerado, basearamse somente nos resultados das safras destas regiões, chegando a conclusões e previsões equivocadas. Concluiu-se que, embora haja certa concentração da produção de feijão no Brasil, a produção pulverizada desempenha papel importante no comportamento do mercado.

Quanto aos preços recebidos pelos produtores, após o Plano Real, sofreram uma queda de cerca de $33,9 \%$, e os preços ao varejo e atacado sofreram uma diminuição de $33,5 \%$ e $25,2 \%$, respectivamente. As margens de comercialização relativas, entre atacado e varejo e entre varejo e produtor, aumentaram, indicando que o consumidor pagou mais pelos serviços de intermediação. Finalmente, confirmou-se o papel do setor intermediário de abrandar choques. Desta forma, apesar das mudanças de estratégias no mercado atacadistas, não foram encontrados elementos que indiquem mudanças substanciais na comercialização.

Em relação ao consumo per capita foi estimada uma redução, em média, de $1 \%$ ao ano, nas três últimas décadas. Esta tendência porém, não é linear, existindo oscilações entre anos. A projeção para o período de 2000 a 2005 permitiu indicar a manutenção da redução do consumo. 


\title{
THE COMMERCIALIZATION OF BEANS IN BRAZIL 1990-99
}

\author{
Author: CARLOS MAGRI FERREIRA \\ Adviser: Prof. Dr. GERALDO SANT'ANA DE CAMARGO BARROS
}

\section{SUMMARY}

The objective of this work was to study how commercialization of beans evolved in Brazil during the 1990's, given particular attention to the influence of the "Plano Real" in the bean market. The evolution of the production of beans according to geographic regions and periods of harvest, as well as their flows of distribution, were studied. In addition the was demand projected demand until the year 2005. The ratio between the prices paid to farmers in the seven largest bean producer states of the country and the wholesale and retail prices in the city of São Paulo were developed. The rates marketing margins were also estimated. Econometric studies were developed in order to identify the direction of causality in price formation.

The results obtained indicate that the "Plano Real" did not have significant impact in the amount of beans produced by the traditional major 
producer states, whereas the imports of beans were significantly increased. Results obtained reveal that after "Plano Real" there was some production alternation among the regions studied with an increasing trend observed in the Northeast Region. No significant changes were observed, however, on the amount produced by traditional bean producer States. On the other hand, bean importats was significantly increased. Some micro regions within those states were identified as very important and stable centers of bean production in the country. The study showed that in spite of some regions concentrate a large amount of the national production, the scattered production in other regions of the country plays a very important role in the national bean market.

After the introduction of the "Plano Real", prices paid to farmers fell by approximately $33,9 \%$, and the retail and wholesale prices dropped respectively by $33,5 \%$ and $25,2 \%$. The commercialization margins of retailers over wholesale prices, as well as of retailers over producer prices, were increased. Hence, consumers have paid more for the intermediation services. The markup of wholesalers over producer prices shrank. The cushioning role of intermediaries in lessening chocks was confirmed. Despite the changes observed in the strategy used by wholesalers, the study did not find indications of substancial alterations in bean possible tendencies of rupture between the commercialization. Some fluctuation among productive regions and some evolution in the strategies of wholesalers were identified during the period of analysis.

The tendency for a decreasing per capita consumption of beans was corroborated, and such a fact was estimated to amount to $1 \%$ per year. This tendency, however, is not entirely linear. It presents oscillations from year to year. The estimation of the national consumption of beans for the period from 2000 to 2005 projects the persistence of the decreasing per capita consumption. 


\section{INTRODUÇÃO}

O objetivo do presente trabalho é, embasado em conceitos e modelos utilizados na "economia da comercialização agrícola", estudar os reflexos sobre a produção e comercialização de feijão no Brasil causados pelas medidas macroeconômicas e setoriais ocorridas na década de 1990. Também é escopo do trabalho fazer uma projeção de demanda até 2005.

O feijão foi o produto escolhido devido à sua importância econômica e social no Brasil, que é grande produtor mundial desta leguminosa ${ }^{2}$. Apesar disso, $2 \%$ a $5 \%$ do abastecimento interno são complementados por produto importado - o Brasil disputa com o Japão a condição de maior importador. Por outro lado, o feijão é de suma importância, sob o ponto de vista alimentar, como alternativa econômica de exploração agrícola em pequenas propriedades e como atividade de ocupação de mão-deobra menos qualificada em várias regiões rurais.

${ }^{1}$ Comercialização compreende "o conjunto de atividades realizadas por instituições que se acham empenhadas na transferência de bens e serviços desde o ponto de produção inicial até que eles atinjam o consumidor final (conceito de Piza \& Welsh citado em Barros, 1987) .

${ }^{2}$ É importante frisar que cerca de $20 \%$. da produção nacional refere-se ao feijão caupi, também denominado de feijão de corda, macassar, macacar, feijão de praia, feijão de colônia, feijão miúdo, feijão fradinho. O consumo e produção desta espécie estão concentrados na Região Nordeste. Nesta região, cerca de $60 \%$ da área plantada e $50 \%$ da produção é de caupi. 
Apesar desses aspectos, estudos da economia do feijão são raros. Esta afirmativa pode ser confirmada considerando que, proporcionalmente a outras culturas de interesse econômico no Brasil, o número de publicações e trabalhos relacionados com a economia do feijão é inexpressivo. Outro problema é que a maioria das publicações aborda com muita ênfase a situação de um determinado local, quando muito o comportamento de algumas outras regiões produtoras e praticamente não existem estudos relacionando a produção e consumo com os eventos macroeconômicos. Por não se fazer estudos abrangentes sobre feijão, existem poucas informações disponíveis, Face a esta situação, o feijão possui o estigma de "produto complicado".

Neste contexto derivam muitas dúvidas e inseguranças para todos os segmentos envolvidos na cadeia produtiva do feijão. Os produtores são prejudicados porque têm dificuldades para obter informações e acabam tendo prejuízos na venda de suas produções. Desta forma, não arriscam fazer investimentos que poderiam tornar a cultura mais eficiente e segura. Certamente, esse fato seja um dos motivos pelos quais o rendimento médio persiste, há muitos anos, na faixa de $550 \mathrm{~kg} / \mathrm{ha}$, enquanto o de outras culturas tem apresentado ganhos substanciais. Ë óbvio que a baixa produtividade do feijão tem origens mais complexas, pois é uma conjunção de várias causas, como o cultivo em consórcio, doenças, baixo nível de adoção de tecnologia e outros.

O baixo rendimento da cultura tem como implicação direta para o produtor a constante ameaça da sua renda. Os empacotadores e varejistas também são prejudicados, pois os negócios só são feitos em curto prazo. Isto inibe os investimentos de longo prazo que poderiam melhorar a 
competitividade $^{3}$ de suas empresas. Conseqüentemente os consumidores são afetados por essas instabilidades, pois os gastos com a aquisição do produto podem afetar o seu orçamento familiar. Mas o maior problema para o consumidor está relacionado com a insegurança quanto à quantidade e qualidade do alimento que é básico na sua dieta.

Assim, o propósito final do trabalho é estudar causas e efeitos de algumas relações ao longo da cadeia produtiva, relacionadas, principalmente, com a produção e comercialização. Assim, talvez, os atores desta cadeia produtiva passem a ter um entrosamento maior e encontrem um caminho para corrigir óbices que limitam eficiência do setor.

\subsection{Um breve histórico da comercialização, produção e do consumo de feijão no Brasil}

Com o propósito de oferecer subsídios que permitam um melhor entendimento do assunto a ser tratado, a seguir apresenta-se uma um breve histórico da comercialização, produção e consumo de feijão no Brasil.

\subsubsection{Produção}

Observa-se na Tabela 1 a área, produção e rendimento de feijão no Brasil no período de 1960 a 1999. Considerando as médias das décadas, observa-se que as seguintes taxas de crescimento; 1,045 para a área e 1,074 para a produção, no mesmo período a taxa de crescimento da população foi de 2,33. A partir destes dados deduz-se que o rendimento da cultura apresentou um pequeno crescimento e que o consumo per capita diminuiu. Posteriormente estes assuntos serão tratados com detalhes. Um aspecto interessante que se

\footnotetext{
${ }^{3}$ Competitividade refere-se à sobrevivência das firmas no longo prazo, através de custos baixos e lucros compatíveis (Anefalos \& Caixeta Filho, 1998)
} 
observa na Tabela 1, é que entre os anos das décadas de 60,70 e 80 o comportamento da área plantada foi estável, apresentando pequenas variações, mas com uma tendência de crescimento. Por outro lado, o comportamento foi instável na década de 90, apresentando variações de até 40\% - Entre os anos de 1993 e 1994 a área plantada aumentou 1583,9 mil hectares. Com relação a produção total esta década apresentou variação positiva de 35\% entre os anos 1993 e 1994 e variação negativa de 28\% entre 1997 e 1998, mas considerando as médias dos três primeiros anos e dos três últimos anos, abstraindo os efeitos dos anos de transição do Plano Real, encontra-se uma taxa de crescimento de 1,024, que corresponde a um crescimento de aproximadamente 4,5\%. Desta forma, pode-se considerar que a produção manteve-se praticamente estável na década de 90 (Figura 1).

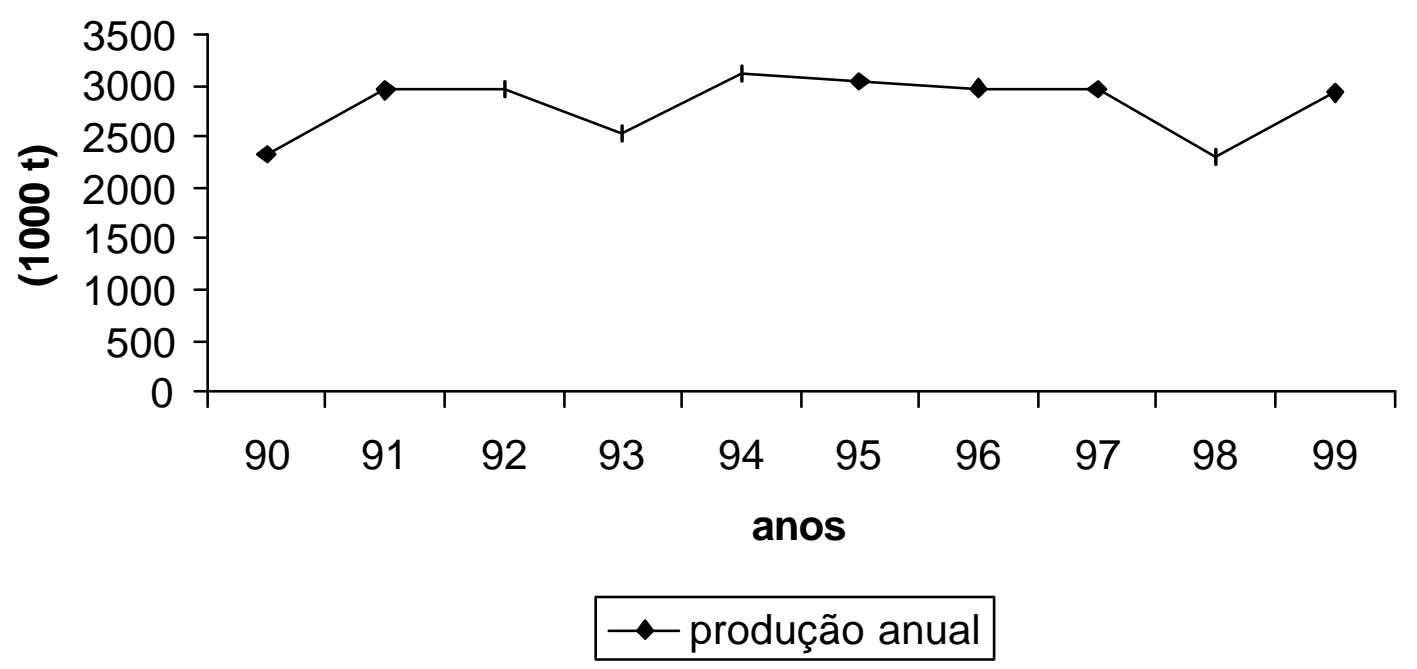

Figura 1 - Produção média anual de feijão no Brasil, no período 1990-99 (em 100- t).

Fonte: Levantamento Sistemático da Produção (IBGE 1990...), adaptado pelo autor 


\subsubsection{Preços}

Pode ser visto na Figura 2 o comportamento dos preços no período de 1960 a 1970. As causas das variações foram atribuídas aos fatos de a cultura ser sensível às questões climáticas e de ser de difícil armazenamento. Desde modo, o comportamento dos preços era fortemente relacionado com a produção. Além disso, era nítida a variação estacional de preços em função das épocas de maior concentração de colheitas, ocorrendo preços mais baixos em janeiro e julho e preços altos nos períodos de entressafra, geralmente em abril e novembro (Junqueira et al. 1971). 
Tabela 1. Área (1000 hectares), produção (1000 toneladas) e rendimento (kg/ha) do feijão no Brasil no período de 1960 a 1999.

\begin{tabular}{l|c|c|c|c|c|c|c|c|c|c|c|c}
\hline \multirow{2}{*}{ Ano } & \multicolumn{3}{|c|}{ Década 60 } & \multicolumn{3}{c|}{ Década 70 } & \multicolumn{3}{c|}{ Década 80 } & \multicolumn{3}{c}{ Década 90 } \\
\cline { 2 - 13 } & Área & Prod & Rend & Área & Prod & Rend & Área & Prod & Rend & Área & Prod & Rend \\
\hline 0 & 2560,2 & 1730,7 & 676 & 3484,7 & 2211,4 & 634 & 4643,4 & 1968,1 & 423 & 4680,0 & 2233,1 & 477 \\
1 & 2580,5 & 1744,5 & 676 & 3936,2 & 2687,9 & 682 & 5026,9 & 2340,9 & 465 & 5442,9 & 2749,4 & 505 \\
2 & 2716,2 & 1708,9 & 629 & 3971,0 & 2676,2 & 673 & 5926,1 & 2902,6 & 489 & 5150,3 & 2799,2 & 543 \\
3 & 2982,4 & 1942,3 & 651 & 3815,4 & 2232,0 & 584 & 4064,0 & 1580,5 & 388 & 3885,1 & 2477,2 & 637 \\
4 & 3130,5 & 1950,6 & 623 & 4288,5 & 2238,0 & 521 & 5320,1 & 2625,6 & 493 & 5469,0 & 3368,4 & 615 \\
5 & 3272,5 & 2289,7 & 699 & 4145,9 & 2282,4 & 550 & 5317,0 & 2548,3 & 479 & 4996,0 & 2946,2 & 589 \\
6 & 3324,5 & 2148,1 & 646 & 4059,1 & 1840,3 & 453 & 5484,5 & 2219,4 & 404 & 4956,8 & 2836,5 & 572 \\
7 & 3650,5 & 2547,5 & 697 & 4551,0 & 2290,0 & 503 & 5221,7 & 2006,0 & 384 & 4880,4 & 3072,9 & 629 \\
8 & 3663,3 & 2419,6 & 660 & 4617,2 & 2193,9 & 475 & 5904,5 & 2900,7 & 491 & 3313,1 & 2187,8 & 660 \\
9 & 3633,2 & 2199,9 & 605 & 4212,4 & 2186,3 & 519 & 5175,2 & 2308,3 & 446 & 4178,4 & 2888,9 & 691 \\
\hline $\mathrm{M}^{*}$ & 3151,4 & 2068,2 & 656 & 4108,1 & 2285,8 & 559 & 5208,3 & 2340,1 & 446 & 4695,2 & 2756,0 & 592 \\
\hline
\end{tabular}

Fonte: Levantamento Sistemático da produção (IBGE, 1990...), adaptado pelo autor 


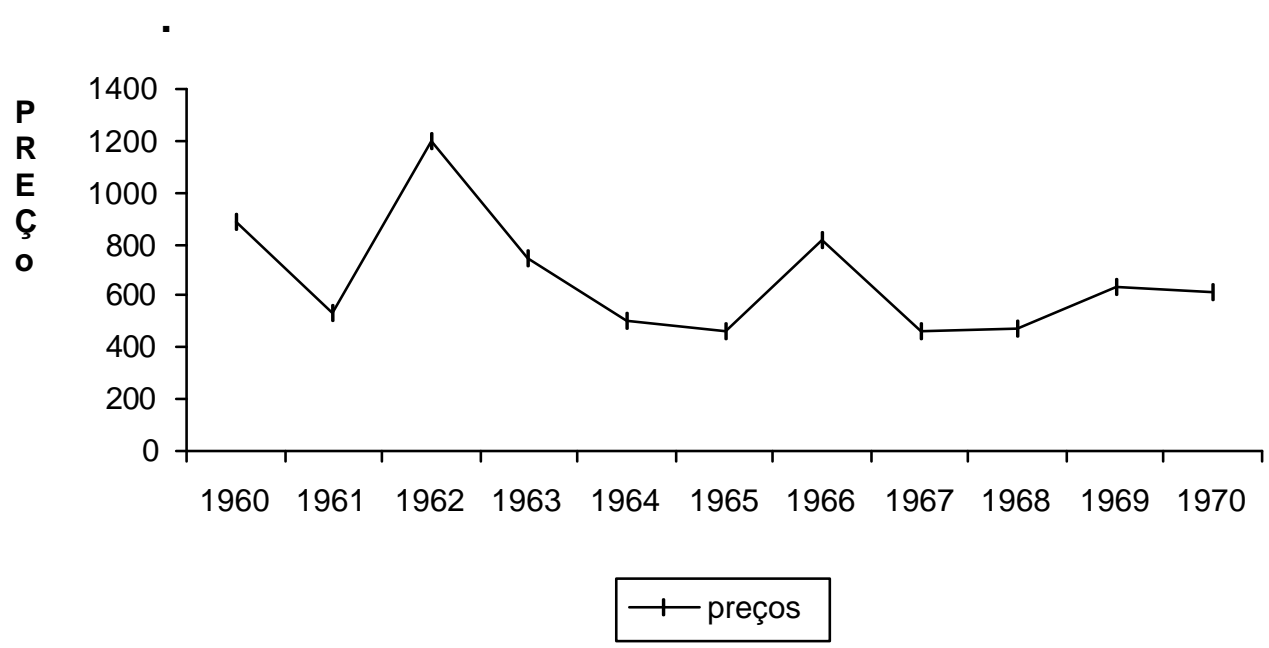

Figura 2 - Preços da tonelada de feijão no Estado de São Paulo, no período de 1960 a 1970. Valores deflacionados pelo índice geral de preços, da Fundação Getúlio Vargas - 1969.

Fonte: Junqueira et al. 1971, adaptado pelo autor.

Na Figura 3 visualiza-se que no período de 1985 a inicio de 1989 os preços médios recebidos pelos produtores foram praticamente estáveis. Neste período o valor médio pelo saco de sessenta quilos, deflacionados para janeiro de janeiro de 2000 , foi de $R \$ 104,25$. No decorrer do ano de 1889 ocorreram fortes alterações. Na década de 90 o preço médio foi de $\mathrm{R} \$ 64,50$. Observa-se ainda na figura que a linha de tendência do preços nominais é decrescente. 


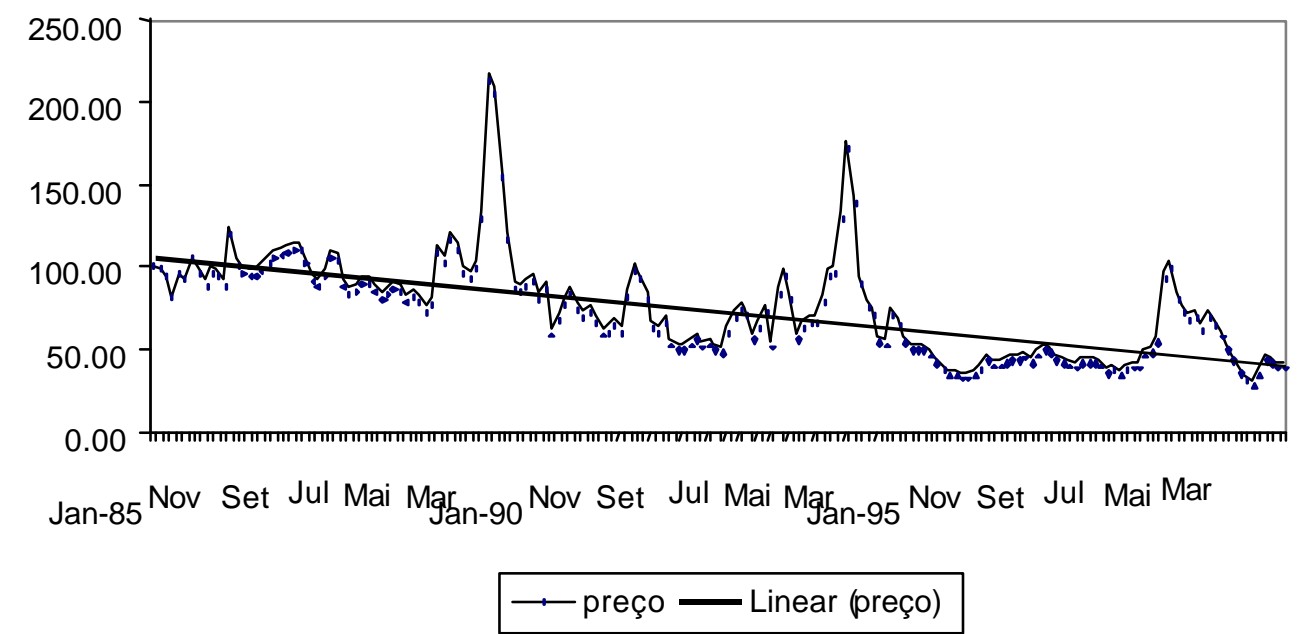

Figura 3 - Preço médio mensal recebido pelos produtores de feijão (saco 60 quilos), no período de 1885 a 1999. Valores em Real deflacionados para janeiro de 2000.

Fonte: Conab*, adaptados pelo autor.

* dados de publicações eletrônicas recebidos por e-mail

\subsubsection{Abrangência geográfica e temporal da produção de feijão no Brasil}

Observa-se na Tabela 2 o princípio que é mais utilizado para divulgar a oferta de feijão, ou seja, os meses de maior concentração de colheitas das grandes safras. Este calendário agrícola pode ser resumido da seguinte forma: a primeira safra é cultivada principalmente nas regiões Sul e Sudeste e na Região da Bahia (Irecê), cuja colheita está concentrada entre os meses de dezembro e março. A segunda safra ocorre entre os meses de abril e 
agosto. A terceira safra, em que predomina o cultivo de feijão irrigado, está concentrada nos Estados de Minas Gerais, São Paulo, Goiás e Bahia. A produção desta safra, normalmente, é ofertada no mercado de julho a outubro.

Tabela 2. Distribuição das épocas de colheita das grandes safras de feijão nos principais Estados produtores e no Nordeste do Brasil.

\begin{tabular}{|c|c|c|c|c|c|c|c|c|c|c|c|c|}
\hline \multirow[t]{2}{*}{ Estado } & \multicolumn{12}{|c|}{ Época de colheita e indicação da safra* } \\
\hline & Jan & $\mathrm{Fev}$ & Mar & $\mathrm{Ab}$ & Mai & Jun & Jul & Ago & Set & Out & Nov & Dez \\
\hline RS & 1 & 1 & & 2 & 2 & & & & & & 1 & 1 \\
\hline SC & 1 & 1 & & 2 & 2 & & & & & & 1 & 1 \\
\hline PR & 1 & 1 & \begin{tabular}{l|l}
1 & 2 \\
\end{tabular} & 22 & 2 & & & 3 & 3 & 1 & 1 & 1 \\
\hline SP & 1 & & & 2 & 2 & 2 & 2 & 33 & 3 & & & \\
\hline MG & 1 & 1 & 1 & & & & 3 & 3 & 3 & & & \\
\hline $\mathrm{BA}$ & 1 & 1 & 1 & & 2 & 2 & 2 & 33 & 3 & & & \\
\hline GO & 1 & 1 & & 2 & 2 & & & 3 & 3 & & & \\
\hline MT & & & & 2 & 2 & 2 & 2 & 3 & 3 & & & \\
\hline MS & 1 & & & 2 & 2 & & & 3 & 3 & & & \\
\hline R0 & & & & & 2 & 2 & & & & & & \\
\hline $\mathrm{NE}^{* \star}$ & & & & 2 & 2 & 2 & & & & & & \\
\hline
\end{tabular}

Fonte: Stone \& Sartorato (1994), adaptados pelo autor.

*1 = primeira safra ou safra das águas;

${ }^{*} 2$ = segunda safra ou safra da seca

${ }^{*} 3=$ terceira safra ou safra de inverno

${ }^{* *} \mathrm{NE}=$ Região Nordeste, exceto o Estado da Bahia.

A grande falha deste sistema é que ele padroniza as épocas de colheitas, quando elas praticamente se realizam o ano todo. Outro problema é que determina períodos para caracterizar cada safra. No entanto, sabe-se que estes períodos podem apresentar variações de ano para ano, em algumas regiões são mais extensos e que, inclusive, pode haver sobreposição de épocas. 


\subsubsection{Consumo}

A Tabela 3 apresenta o consumo per capita de feijão ao longo dos últimos 40 anos. Duas situações chamam a atenção nos dados: a primeira é a alternância de consumo entre os anos e a segunda é que no ano de 1995, após o Plano Real, houve um aumento do consumo, e que, a partir de 1996, voltou a cair. Este resultado permite conjeturar que, após o Plano Real, houve um crescimento somente de consumo daqueles alimentos que anteriormente eram considerados produtos de classes mais ricas ${ }^{4}$.

Tabela 3. Consumo per capita aparente de feijão no Brasil kg/habitante/ano.

\begin{tabular}{|c|c|c|c|c|}
\hline \multirow{2}{*}{ Anos } & \multicolumn{4}{|c|}{ Décadas } \\
\hline & 60 & 70 & 80 & 90 \\
\hline 0 & 22,20 & 21,50 & 13,58 & 14,53 \\
\hline 1 & 22,01 & 25,52 & 17,44 & 15,86 \\
\hline 2 & 20,92 & 24,64 & 22,78 & 16,66 \\
\hline 3 & 23,09 & 20,84 & 12,52 & 16,94 \\
\hline 4 & 22,42 & 19,52 & 18,78 & 18,65 \\
\hline 5 & 25,71 & 18,43 & 15,80 & 18,86 \\
\hline 6 & 23,43 & 15,53 & 15,54 & 18,63 \\
\hline 7 & 27,03 & 18,90 & 14,57 & 17,96 \\
\hline 8 & 24,38 & 18,11 & 16,78 & 13,90 \\
\hline 9 & 21,37 & 16,78 & 16,16 & 16,01 \\
\hline Média & 23,25 & 19,97 & 16,39 & 16,80 \\
\hline
\end{tabular}

\footnotetext{
${ }^{4}$ Balanço divulgado no Jornal Estado de São Paulo, em 04/07/97, pelo ministro da Agricultura, Arlindo Porto, em que com três anos de Plano Real o consumo per capita de carnes aumentou de 57 quilos ao ano para 65 quilos e o de leite de 111 litros para 138 litros por ano. Também cresceram as vendas de iogurtes (98\%), cereais matinais (223\%), leite longa vida (148\%) e o consumo de bebidas esportivas subiu $757 \%$.
} 


\subsubsection{Resenha dos principais acontecimentos relacionados com 0 mercado de feijão na década de 1990.}

A resenha da produção e comercialização de feijão no Brasil na década de 1990, foi feita baseando-se num levantamento das publicações que abordam sistematicamente o mercado deste produto, as fontes consultadas foram: a) Instituto de Economia Agrícola da Secretaria de Agricultura do Estado de São Paulo - IEA (Informações Econômicas, 1990...); b) Revista Acompanhamento da Situação Agropecuária do Paraná. (Paraná, 1990...); c) Jornal da Bolsa de Mercadorias do Estado de Goiás - (Informativo da Bolsa de Mercadorias do Estado de Goiás, 1994....); d) Universidade Federal de São Paulo, Centro de Estudos Avançados em Economia CEPEA (Preços Agrícolas, 1997...). Uma síntese desta pesquisa é apresentada a seguir:

A área plantada na primeira safra $89 / 89$ foi maior do que em anos anteriores, mas, devido a fatores climáticos e baixo uso de tecnologias, nos Estados da Região Centro-Sul do País a produção foi menor do que a estimada, e o feijão ofertado pelo Paraná foi considerado de baixa qualidade. Em março/90, foi editado o Plano Brasil Novo, mais conhecido como Plano Collor I. As principais medidas implantadas com interesse para o estudo são: 0 bloqueio de recursos financeiros da população e um novo congelamento de salários e preços. Medida que vigorou até o dia três de setembro/90 quando os preços foram liberados. Neste aspecto, este plano diferenciava dos anteriores porque o congelamento não era rígido.

Em maio/90, mesmo vigorando o tabelamento, o Governo permitiu o reajuste para o feijão Assim, o produto, que estava faltando no mercado, voltou a ser ofertado. Em função do clima, o plantio da segunda safra $89 / 90$ foi retardado. A expectativa era de que haveria um aumento da área plantada, principalmente no Estado de São Paulo. Porém, novamente, a 
produção foi menor do que a prevista; o motivo alegado foi que os produtores estavam receosos com o tabelamento. Assim, a conjetura para o segundo semestre/90 era de alta dos preços. No entanto, tal fato não ocorreu, e a justificativa foi que o poder aquisitivo da população estava baixo. Convém lembrar que isto ocorreu logo após a implantação do Plano Collor I. A terceira safra 90/91 também foi prejudicada pelo clima. Em setembro/90 e outubro/90, os supermercados fizeram promoções com feijão de baixa qualidade. Nesta época, o Governo divulgou medidas para estimular o plantio. Em dezembro/90, o preço foi baixo por causa do Natal e da boa oferta.

Em fevereiro/91, foi editado o Plano Collor II, acompanhado de um novo congelamento temporário de preços. Em março/91, vigorava o tabelamento do Plano Collor II, mas ocorreu um reajuste de 9,3\% para o feijão carioquinha. Para segunda safra 90/91, os ânimos dos produtores, principalmente dos paulistas, estavam arrefecidos com a persistência do tabelamento. Já os produtores mineiros e goianos estavam ampliando as áreas plantadas. Em maio/91, o Governo adota novas políticas para incentivar a cultura e, em julho/91, acaba o tabelamento. Em agosto/91, o governo reafirma seu incentivo.

Devido ao atraso no plantio da primeira safra de 91/92, por problemas climáticos, ocorreu coincidência de colheita entre as regiões produtoras. Para a segunda safra 91/92, muitos produtores, motivados pelos preços obtidos em períodos anteriores, resolveram entrar na atividade, mas, como os juros estavam altos, muitos utilizaram recursos próprios para o custeio. O desfecho desta safra foram os preços baixos, porque ocorreu excesso de oferta em virtude da boa produção, e porque os produtores precisavam vender logo a produção para saldar dívidas feitas com cultivo da cultura. Porém o mercado reagiu com a notícia de queda da safra da Região Nordeste e os preços voltaram a subir. Em agosto/92, o Governo surpreendeu o mercado 
anunciando medidas para desestimular o plantio. Nos meses de setembro a novembro/92 a oferta foi baixa e a Companhia Nacional de Abastecimento Conab - passou a realizar sistematicamente leilões.

No início de 1993, o consumo foi baixo, havia excesso de oferta e o governo comprou feijão, principalmente em Santa Catarina, para distribuir em seus programas assistenciais. O plantio da segunda safra 92/93 foi atrasado e ocorreu quebra de safra na Região Nordeste.

A produtividade na primeira safra 93/94 foi baixa. Além disso, ocorreu quebra na Bahia (Irecê) e a safra de Santa Catarina foi prejudicada por excesso de chuvas. Diante deste quadro, os atacadistas entraram comprando, tentando fazer estoques. Como era de se esperar, os preços subiram e criou-se a expectativa de que haveria aumento da área plantada na segunda safra 93/94, inclusive na Região Nordeste. Em maio/94, de novo os supermercados fizeram promoções de feijão. O prognóstico para o segundo semestre/94 era de que, em função da boa colheita, os preços ficariam estáveis. Em junho/94, ocorreram geadas e foram estimadas perdas de 50\% na Região Sul. Apesar disto, os preços permaneceram estáveis. Segundo os analistas, isto ocorreu porque o consumo estava baixo, em virtude de que a população tinha mudado seus hábitos alimentares devido ao aumento do poder aquisitivo já no período de preparação de implantação da nova moeda, ou seja, com a política de Unidade de Referência de Valor - URV.

No dia primeiro de julho de 1994, foi editado o Plano Real. Neste Plano, a contribuição do setor agrícola no controle da inflação ocorreu via redução dos preços dos produtos agrícolas, fato que também ficou conhecido pela expressão "âncora verde". Outro elemento importante foi a redução das alíquotas de importação. 
O plantio da primeira safra 94/95 na Região Centro Sul ${ }^{5}$ foi retardado. Por outro lado, tinha ocorrido quebra na segunda safra93/94 e os estoques do Governo estavam baixos. Logo, os atacadistas imaginaram que faltaria feijão, principalmente em novembro/94 e dezembro/94, e tentaram fazer estoques. A conseqüência óbvia foi o aumento dos preços. Diante desta crise, o Governo, através da Portaria 528 de 07/10/94, ameaçou a aplicação do confisco de estoques.

Na primeira safra 94/95, ocorreram perdas estimadas em $50 \%$ no Estado do Paraná. As chuvas também prejudicaram a produção de Santa Catarina e São Paulo e a Bahia (Irecê) também tinha perdido parte de sua safra. Mesmo diante desta situação, os preços não foram afetados de forma significativa. Alegavam que o Plano Real permitiu que o consumidor substituísse o feijão por outras proteínas de origem animal, por isso a demanda era baixa, provocando redução no preço do feijão. Na segunda safra 94/95, o Nordeste colheu uma boa safra, o que contribuiu para estabilidade do mercado nos meses de agosto e setembro/95.

O início da colheita da primeira safra 95/96 foi marcado pelas quebras nos Estados do Sul. Foram verificados aumentos de preços de até $80 \%$. Em janeiro/96, houve redução da safra no Paraná, Santa Catarina e Rio Grande do Sul e Bahia, mas, com a regularização das colheitas, os preços voltaram ao normal. Nos meses de abril e maio/96, os preços subiram em função da baixa oferta causada pela queda nas produções das Regiões Sudeste e Centro-Oeste. Neste período, os empacotadores estavam reduzindo a margem para não haver maior recuo na demanda. Outra medida que o mercado de feijão estava praticando, era comprar grande parte do produto

\footnotetext{
${ }^{5}$ Neste estudo considera-se que a Região Centro Sul é formada pelos Estados das Regiões Sul, Sudeste e Centro-Oeste e o Estado da Bahia.
} 
diretamente do produtor, pois eram reduzidos os volumes disponíveis na zona cerealista de São Paulo.

O mês de julho/96 iniciou com altas de preços no mercado atacadista paulista. A alta foi atribuída a três fatores: primeiro, atraso nas colheitas causado pelas baixas temperaturas que retardaram o ciclo do feijão plantado; segundo, procura maior pelos atacadistas da Região Nordeste de feijão na Região Sul; terceiro parte do feijão estava sendo adquirido em Rondônia, assim o custo de transferência era maior. Na segunda quinzena, o mercado apresentou queda nos preços.

Em agosto/96, a expectativa de quebra não se confirmou e o mercado presumiu que estava ocorrendo retenção por parte dos produtores nas zonas produtoras. No mês de setembro/96, os preços subiram sob a alegação de que, devido às chuvas, estava ocorrendo atraso na colheita do feijão irrigado. Outro argumento utilizado para justificar os altos preços no varejo foi que a mercadoria estava sendo adquirida a um preço elevado devido aos custos de transferência e ao Imposto Sobre Circulação de Mercadorias - ICMS. No mês de novembro/96, o mercado paulista foi marcado por um período de escassez e outro de oferta regular com produto do próprio Estado.

Em janeiro/97, novamente, após quatro anos de frustração de safras, a região de Bahia (Irecê) voltou a produzir. Em compensação, os Estados do Paraná e Santa Catarina colhiam boas safras, mas ofertavam produtos com baixa qualidade. Esta mercadoria foi destinada ao mercado Nordestino. Assim, o remanescente da colheita realizada em dezembro/96 em São Paulo foi responsável pelo abastecimento do mercado paulista. Em fevereiro/97, as colheitas no Sul do País, em Minas Gerais, Bahia e Goiás foram prejudicadas pelas chuvas. As altas de preços ocorridas em março/97 foram justificadas pelos problemas com as chuvas, principalmente na região de 
Bahia (Irecê), que tem papel importante no abastecimento da Região Nordeste. Destarte, esta região ficou desabastecida e demandou mais produto da Região Centro Sul, provocando maior competição e conseqüente aumento de preços.

Em geral, a tendência no mês de abril é de redução dos preços em relação ao mês anterior, porque se inicia a colheita da segunda safra em vários Estados. Mas no mês de abril/ 97, devido à estiagem no sul do País que provocou uma queda de safra, principalmente no estado do Paraná, e das chuvas que atrasaram a colheita em São Paulo, o mercado ficou apreensivo, apresentando oscilações de preços. Os empacotadores reclamavam que não conseguiam repassar os preços; assim, compravam menos, na tentativa de abaixar a demanda e induzir a redução dos preços. Criou-se um pessimismo em relação ao segundo semestre/97, prevendo-se que o mercado necessitaria de grandes volumes de produtos importados da Argentina, Estados Unidos, Chile e China.

Apesar das previsões sombrias, em maio/97 o mercado do feijão mostrou-se calmo e com preços em queda durante todo o mês. O abastecimento foi feito pela safra de Bahia (Irecê) e dos Estados do Sul do País, notadamente Paraná, Santa Catarina, Rondônia, São Paulo e a safrinha de alguns Estados nordestinos. Em junho/97, o mercado ficou calmo, com tendência de queda nos preços.

Em virtude do prognóstico de redução da terceira safra/97, em junho desse ano voltaram as previsões da necessidade de importação no segundo semestre/97. Mais uma vez, em poucos dias, o rumo dos negócios mudaram radicalmente, pois, já na segunda quinzena do mês, o mercado apresentava boa oferta, inclusive com redução nos preços. A situação permaneceu do mesmo jeito no período de julho a setembro/97. Nos meses de 
outubro e novembro/97, também não ocorreu qualquer mudança que mereça citação diante do escopo do trabalho.

Dezembro, normalmente, é um mês calmo, mas, devido à quebra de safra ocorrida na Região Sul, neste ano apresentou flutuação de preços durante todo o mês, principalmente dos produtos de boa qualidade. Outra variável neste contexto foi a maior procura por parte dos compradores nordestinos por feijão no interior de São Paulo.

Pelos motivos elencados no parágrafo anterior, em janeiro e fevereiro/98, o mercado de feijão manteve a tendência de alta dos preços iniciada em dezembro/97. Em março/98, o mercado estava desnorteado, vigoravam especulações e os preços variavam conforme mudanças no clima das regiões produtoras de Minas Gerais, Santa Catarina e Goiás.

No mês de abril/98, em decorrência da seca na Região Nordeste, os compradores daquela região tentavam obter mercadoria nas Regiões Sul e Sudeste, que, por sua vez, enfrentavam problemas com as chuvas. Portanto, o mercado estava operando com pequena oferta, assim, os preços disparam em todas praças. Por exemplo, o feijão carioca, mesmo o de qualidade inferior, apresentou elevação de mais de 100\%. Os Estados de Goiás e Minas Gerais foram os mais regulares no abastecimento. Durante o mês de maio/98, ocorreram variações nos preços, mas persistiu a tendência altista. No mês de junho/98, a entrada das safras irrigadas, principalmente de Goiás e Minas Gerais, reverteu a tendência altista que predominava nos últimos meses. Segundo informações dos supermercados, a alta de preços provocou uma redução de 30\% a 40\% no consumo de feijão. Quando a expectativa era de que o mês de julho/98 fosse calmo, o mercado de feijão surpreendeu novamente e apresentou preços elevados, tendo sido abastecido por produtos originados nas lavouras irrigadas de Goiás. 
Em agosto/98, foi mantida a situação de preços altos. Foram apontadas como causas: o clima da Região Centro-Oeste que, em algumas regiões, foi muito seco, e a ação do Governo, que adquiriu cerca de 19 mil toneladas do produto para a composição das cestas básicas distribuídas à população. Durante o mês de outubro/98, os preços sofreram reduções gradativas.

Geralmente, o mês de novembro, por ser um período de transição, quando se inicia a colheita da primeira safra, é um período incerto, e o mercado fica à mercê das especulações. Assim, segundo a tradição, em 1998, neste mês o mercado de feijão foi volátil, apresentando tendência de baixa no início do mês, quando a expectativa da colheita era positiva, e alta no final do mês frente às noticias de perdas nas lavouras paranaenses e paulistas. Em dezembro/98, ocorreu nova instabilidade de preços, só que desta vez com preços altos no inicio e redução no final, quando a colheita se estabilizou nos Estados da Região Sul.

No mês de janeiro/99, o fenômeno de falta de previsibilidade se repetiu, com preços altos no inicio do mês, porque a oferta estava baixa, mas, a partir da metade do mês, com o aumento de oferta, o mercado tomou novo rumo com quedas de preços. Ou seja, período com oscilações de preços por motivo temporário e de curta duração. Em fevereiro/99, os preços foram baixos, mas em março/99 os preços iniciaram o mês com tendência altista, posição derivada das notícias de redução de produção no Sul do País e na Bahia (Irecê). Especulava-se também que os produtores do Centro-Oeste estariam retendo o produto.

Ao contrário do que vinha ocorrendo, em abril/99, o mercado de feijão teve um comportamento estável. As explicações para tal situação foram: 
ausência de pressões de compra em todos os níveis de mercado; regularidade da oferta; bom desenvolvimento das lavouras no sul do País, que na prática não foram prejudicadas pelas baixas temperaturas que atingiram a região conforme notícia veiculada.

Nos meses de maio $^{6}$ a julho/99, o mercado de feijão manteve a tendência de queda verificada nos meses anteriores. Porém, em agosto/99, o mercado mostrou por que o feijão é considerado um dos produtos mais instáveis e surpreendeu com variações de preços superiores a $100 \%$. Desta vez, a culpa foi imputada às condições climáticas nas regiões produtoras, ou seja, excesso de chuva na região norte da Bahia, Sergipe e Alagoas, geadas no sul do País e seca em Goiás, Distrito Federal e Minas Gerais (Unaí).

Em setembro/99, apesar dos problemas com o clima que causaram reduções de produções, os preços ficaram acomodados. O mercado paulista foi abastecido pelas lavouras do interior do Estado. Ao longo do mês de outubro/99, o mercado de feijão revezou períodos de preços em alta e em baixa.

Em outubro/99, o nível de preços foi considerado alto. Assim, os atacadistas e varejistas se valeram da velha tática de operar com produto de menor qualidade para reduzir o preço final. No mês de novembro/99, a gangorra dos preços volta a vigorar, com tendência de queda durante a maior parte do mês e, nos últimos dias, devido à redução da oferta, os preços voltam a subir.

\footnotetext{
${ }^{6}$ O feijão carioca foi lançado em maio de 1969, portanto, estava há 30 anos no mercado.
} 


\subsection{Identificação, caracterização e importância do problema}

Pode-se dividir a década de 90 em dois períodos econômicos, antes e após o Plano Real. O primeiro, caracterizado pela presença ou ameaça de inflação e pela implantação de políticas intervencionistas, tanto no âmbito macroeconômico como em níveis setoriais, principalmente nos processos de comercialização. O segundo período, com maior estabilidade e menor intervenção do governo. Mas, independente do momento econômico, o feijão viveu sob a ameaça de desabastecimento ou de excesso de oferta e pode ser considerado o "campeão" de oscilação de preços.

De acordo com o Centro de Estudos Avançados em Economia Aplicada (1999), três importantes componentes modificadores do cenário político-econômico na década de 90 foram a globalização da economia ${ }^{7}$, a liberalização econômica ${ }^{8}$ e a escassez de recursos públicos ${ }^{9}$. Outras medidas ou situações que merecem consideração são: os três planos macroeconômicos para a estabilização da economia, Plano Collor I, Plano Collor II e o Plano Real; as mudanças na estrutura de comercialização; a alteração do consumo em virtude da modificação do poder aquisitivo da população; as políticas adotadas pelo Governo Federal, principalmente aquelas contidas nos planos de safras relacionadas com o grau de incentivo para a cultura; as intervenções do Governo adquirindo produto para o programa de distribuição de cestas básicas.

Inúmeras características da cadeia produtiva do feijão contribuem para dificultar as condições de comercialização do produto: a abrangência geográfica e temporal da produção e as freqüentes importações do produto; a dispersão geográfica das regiões produtoras provocando um elevado

\footnotetext{
${ }^{7}$ Entendida como um maior interação e influência entre as economias dos diferentes países e blocos econômicos.

${ }^{8}$ Está relacionada com a redução da influência do Estado no funcionamento dos mercados

9 Está associada à liberalização econômica.
} 
nível de circulação do produto, com reflexos nos custos dos transportes ${ }^{10}$; as dificuldades técnicas para o armazenamento ${ }^{11} \mathrm{e}$ a conseqüente inexistência de estoques reguladores ${ }^{12}$; a grande variedade de feijões consumidos; as preferências regionais; as mudanças no hábito alimentar da população; as condições climáticas que afetam a quantidade e a qualidade do produto ofertado; a variação do consumo per capita em diferentes épocas ${ }^{13}$; a utilização do artifício de intermediários e varejistas baratearem o preço final da mercadoria, comercializando produtos de menor qualidade, quando os preços do feijão atingem níveis elevados.

Esta profusão de condicionantes aliada ao baixo interesse dos órgãos oficiais e da comunidade acadêmica em gerar informações e estudos sobre o produto, tornam complexas as análises de mercado do feijão. Esta falta de base deixam aqueles que fazem este tipo de serviço vulneráveis a falhas e erros. Alguns segmentos sabendo destas dificuldades tentam levar vantagens. Desta forma, em qualquer época, quando ocorre qualquer atraso ou ameaça de perda de safra de alguma região estrategicamente importante, estes segmentos tentam causar instabilidade no mercado disseminando notícias que geram movimentos especulativos que lhes favoreçam.

${ }^{10} \mathrm{O}$ deslocamento de grandes distâncias é explicado pelo fato de o consumidor ser exigente por qualidade do produto e ter disposição para pagar mais caro por isso e pelo fato de que as produções de São Paulo e Rio de Janeiro, grandes Estados consumidores, não serem suficientes para o auto-abastecimento, de forma que são abastecidos com produto de outras regiões. No caso do Estado de São Paulo, cerca de 22\% do total consumido é importado de outros Estados.

${ }^{11} \mathrm{O}$ problema de armazenamento afeta principalmente o feijão do tipo carioca, que perde a coloração do tegumento em pouco tempo. Segundo Spers \& Nassar (1998), o produto deve chegar no consumidor em, no máximo, dois meses.

12 O tempo entre a colheita e a aquisição do produto pelo consumidor é curto, quando comparado com o dos outros cereais, sendo às vezes, menor do que uma semana.

${ }_{13}$ Os analistas afirmam que, durante as férias escolares, festas natalinas e carnaval, o consumo é menor. O consumo no inicio do mês é maior porque é a época que a maioria das pessoas recebem os salários 
A ocorrência de variações de preços no mercado de qualquer produto agrícola é normal, pois eles estão afetos às questões climáticas, de entressafra e outros tipos de choques. Mas, no mercado de feijão, os produtores, atacadistas e varejistas têm muitas dificuldades para fazerem projeções, até mesmo de curto prazo, pois, às vezes, é noticiado que o mercado apresenta um déficit e, em questão de dias, encontra-se em superávit. Conseqüentemente, isto provoca oscilações singulares de preços. Outra inferência que se pode fazer é que muitas análises de mercado são feitas utilizando as variáveis supramencionadas, mas, na maioria das vezes, estas não são discutidas com o respaldo de modelos teóricos que sustentem cientificamente as conclusões. Um fato que corrobora esta proposição é que, diante de crises, freqüentemente o mercado entra em equilíbrio com uma rapidez impressionante, a ponto de muitos estudos que utilizam preços mensais ou dados de safras não conseguirem captar essas oscilações.

Em síntese, é comum surgirem previsões alarmistas sobre o comportamento da produção, comercialização e abastecimento de feijão no Brasil, mas, normalmente, os impactos são mais brandos do que os vaticinados. Estas inquietudes que cercam a cadeia produtiva do feijão deixam o mercado inseguro, prejudicando sensivelmente suas relações e constituem um entrave para a sua modernização. Por isso, o feijão é classificado como produto com altos riscos de produção e mercado.

Feitos estes breves comentários sobre aspectos gerais da cadeia produtiva do feijão no Brasil, pode-se ter uma idéia de algumas variáveis sócio-econômicas e de outros fatores que influenciam na oferta e demanda do produto. Evidentemente o trabalho não almeja esgotar o assunto, tampouco tem a pretensão de abordar todas as variáveis apresentadas. Assim, o escopo do trabalho se resume em estudar a reação dos produtores, verificando a origem da produção e a quantidade ofertada, analisar o comportamento das margens 
de comercialização e da transmissão de preços entre os níveis de mercado frente à menor intervenção governamental no processo de comercialização, maior estabilidade econômica e abertura comercial, tendo como ponto referencial o Plano Real.

Outras intenções do trabalho foram: apresentar uma alternativa às tradicionais análises baseadas em resultados das grandes safras de feijão e/ou safras das principais regiões produtoras no País, por uma forma em que a oferta é apresentada mensalmente e fazer uma projeção da demanda.

O principal referencial teórico utilizado é baseado no argumento de Barros (1987), de que o mecanismo de formação de preços nos vários níveis de mercado operam sob dependência de uma superestrutura institucional e que esta é determinada, principalmente, pelo grau de competitividade do mercado e pelo grau e pelo tipo de intervenção governamental no mesmo. Daí resulta um mecanismo de transmissão de preços do consumidor para o produtor e viceversa, através do setor de intermediação. Esse mecanismo reflete, ao mesmo tempo, o grau de apropriação - que pode ser verificado nas margens - por parte dos intermediários do dispêndio do consumidor.

A hipótese é que a estabilidade econômica, a política de abertura de mercado e a menor intervenção do governo na produção e comercialização do feijão, não foram fatores preponderantes para determinar o comportamento da transmissão de preços e das margens de comercialização na década de 1990.

Dentre alguns autores que tratam do assunto comercialização de feijão, destacam-se os trabalhos de Junqueira et al. (1971), Burnquist (1986), Barros (1990), Aguiar et al. (1994) e Spers \& Nassar (1998). Estes trabalhos basicamente utilizam os mesmos princípios teóricos, divergindo 
quanto ao objetivo e forma de aplicação da teoria. O presente trabalho difere destes no sentido que aborda um novo período e realiza, ao mesmo tempo, vários preceitos que foram omitidos ou utilizados de forma isolada nos trabalhos supraditos.

\subsection{Objetivos principais}

\subsubsection{Geral}

- O objetivo principal é, diante das políticas macroeconômica que resultaram na abertura de mercado, menor intervenção do governo na produção e comercialização do produto e na maior estabilidade, analisar os reflexos na produção e da comercialização do feijão na década de 1990, tendo o Plano Real como o fato econômico referencial.

\subsubsection{Específicos}

- Apresentar uma análise crítica quanto à forma como são feitas avaliações e previsões de comportamento do mercado de feijão;

- Verificar que tipo de conseqüências o novo ambiente político-econômico constituído na década de 90 causou à cadeia produtiva do feijão.

\subsection{Delineamento do trabalho}

Neste primeiro capítulo, que introduz o presente estudo, apresentou-se um panorama dos principais eventos econômicos de interesse para esta pesquisa, foi apresentado um breve histórico da produção e comercialização de feijão no Brasil na década de 90, justificou-se o trabalho e comentaram-se as hipóteses e objetivos que o norteiam. 
No capítulo 2, primeiramente serão mostrados resultados de pesquisas já realizadas sobre o assunto e as metodologias utilizadas em outros estudos. Depois será discutido como o presente trabalho se relaciona com outros já feitos e, posteriormente, será feita uma confrontação de metodologias e tipos de dados.

No capítulo 3, primeiramente serão feitos comentários sobre os dados, suas fontes e tratamentos e, num segundo momento, serão abordados outros procedimentos e cálculos realizados, bem como se apresentarão os modelos econométrico e econômico.

O capítulo 4 trará análises dos resultados, mostrando a dinâmica da comercialização entre os Estados e os mercados varejista e atacadista de São Paulo. Finalmente, no capítulo 5 estarão sintetizadas as principais conclusões e algumas sugestões de tópicos que não puderam ser tratados no trabalho. 


\title{
2 REVISÃO DE LITERATURA
}

\begin{abstract}
A revisão da literatura disponível sobre a comercialização de feijão no Brasil pode ser dividida em dois tópicos. O primeiro enfoca as metodologias utilizadas e apresenta resultados de outros trabalhos sobre 0 tema. O segundo relaciona o presente estudo com outros já realizados.
\end{abstract}

\subsection{Resultados de outras pesquisas}

Nesta revisão foi dada maior atenção aos seguintes tópicos:

\subsubsection{Canais de comercialização}

Um dos primeiros trabalhos encontrado sobre o assunto foi feito por Junqueira et al. (1971). Naquela época, anos 60, existiam somente duas safras anuais, a das águas e da seca, e a maior parte do feijão era cultivado em consórcio. A produção dos Estados do Paraná, Minas Gerais, São Paulo, Rio Grande do Sul e Ceará somadas respondiam por, aproximadamente, 62\% da produção de todo o País. Os principais abastecedores da Capital Paulista eram: Paraná 67\%, Rio Grande do Sul 14,1\%, São Paulo 8,9\%, Minas Gerais 5,5\%, Santa Catarina 3,6\% e Goiás 0,9\%. Os principais canais da comercialização de feijão considerados eram a distribuição a partir dos produtores rurais para 0 consumo na própria região, ou vendendo para cooperativas, comerciantes 
primários, caminhoneiros ${ }^{14}$ ou ao governo. Na próxima etapa ocorria uma concentração no mercado varejista. Os atacadistas da Capital Paulista ${ }^{15}$ adquiriam $77 \%$ do feijão dos atacadistas do interior, que eram chamados de maquinistas ou cerealistas, $17 \%$ diretamente dos produtores, $2 \%$ dos caminhoneiros e $4 \%$ de outros atacadistas da Capital. As vendas destes atacadistas em cerca de $52 \%$, eram para outros atacadistas e $48 \%$ para o varejo. Os principais compradores varejistas eram $2 \%$ feiras, $33 \%$ empórios, $33 \%$ supermercados e $9 \%$ mercados distritais e $5 \%$ outros.

Este estudo já observava mudanças na estrutura do canal de comercialização do feijão e destacava como fato relevante a maior influência dos supermercados na distribuição varejista do produto e a grande perda relativa das feiras. Afirmava-se ainda, que os supermercados tinham triplicado sua participação em cinco anos e as feiras tinham perdido a metade de sua importância.

A Pesquisa de Orçamento Familiar - POF-1987/88 (IBGE, 1991) revelou que na Região Metropolitana de São Paulo os supermercados predominavam amplamente no mercado varejista na distribuição de feijão, com participação de $80 \%$. Em seguida, apareciam os armazéns, com $12 \%$, as feiras livres com $3 \%$, os mercados distritais com $2 \%$ e outros com $3 \%$.

Outro estudo foi realizado por Spers \& Nassar (1998) e, de acordo estes autores, no atacado estão os empacotadores, que, estrategicamente, se localizam nas regiões consumidoras. Os empacotadores podem ser divididos em dois grupos, um, que compra direto dos corretores nos

\footnotetext{
${ }^{14}$ Previam que haveria intensificação da ação dos caminhoneiros, a exemplo do que ocorria em outras regiões do País.

${ }^{15}$ Segundo estes autores, na Capital paulista havia 28 grandes atacadistas
} 
locais de produção, ou corretores da bolsinha ${ }^{16}$, e o outro, que compra mercadoria através dos corretores ${ }^{17}$ nas regiões produtoras, ou seja, negociam diretamente com os produtores, cerealistas ${ }^{18}$ e cooperativas. No varejo, outros distribuidores, além dos supermercados, pequenos mercados e feiras são as empresas de cestas básicas e cozinhas industriais. Afirmam os autores mencionados que os supermercados comercializam $77 \%$ do feijão empacotado. Segundo Silva (1996) os supermercados contribuíram para encurtar o número de agentes intermediários no processo de distribuição dos produtos agrícolas.

Estes autores apontam as seguintes barreiras para que membros do primeiro grupo passem para o segundo: a) dificuldades para estruturar equipes de compras para percorrer todas as regiões produtoras brasileiras; b) escala mínima para fornecimento aos supermercados, seguindo o alto padrão de qualidade exigido; c) infra-estrutura de classificação do produto para obtenção dos padrões requeridos; d) saúde financeira para atender às exigências dos supermercados, principalmente a quota inicial gratuita para entrada, desconto nas promoções e prazos de pagamento; e) capacidade de fornecimento quase diário às lojas.

Para Spers \& Nassar (1998), a dificuldade de distribuição do produto é decorrente da dispersão da produção, que gera altos custos de monitoramento da oferta. A freqüência de transações entre os supermercados e os corretores é alta, devido à grande rotatividade provocada pelo elevado consumo per capita e pelos baixos estoques utilizados nos supermercados. Comentam ainda que inexistem contratos de fornecimento de longo prazo.

\footnotetext{
${ }^{16}$ Bolsinha é um local na cidade de São Paulo com destacado papel no comércio de cereais, inclusive de feijão.

17 Corretores, normalmente, não têm controle físico da mercadoria, sua função resume-se apenas em aproximar compradores e vendedores potenciais (Barros 1987)

${ }^{18}$ Segundo os autores, estes elementos atuam como distribuidores atacadistas, mas também como empacotadores.
} 


\subsubsection{Margens de comercialização}

$\mathrm{Na}$ economia da comercialização agrícola, a margem de comercialização é um referencial teórico apropriado para estudar como determinados fatores podem causar alterações nos preços de um produto. Dito de maneira diferente, como os choques são transmitidos aos demais níveis de mercado. Portanto, a margem de comercialização, além de permitir a avaliação de choque na oferta e demanda de produtos, também oferece a possibilidade de compreender a influência dos insumos de mercado.

Margens de comercialização são os lucros ou prejuízos dos intermediários, somados às despesas cobradas aos consumidores pela realização das atividades de comercialização. São apresentadas tanto em valor absoluto ou, percentualmente, como proporção do preço ao varejo. Assim, fornecem o valor, ou proporção, que os consumidores pagam pelos serviços de intermediação.

Quanto aos custos dos insumos de comercialização, vale ressaltar que a variação pode estar relacionada com o comportamento estacional dos preços dos insumos ou com a melhoria do produto final, via introdução de novos processos ou serviços. Pode, ainda, refletir efeitos de políticas implementadas. Outra importante inferência que se pode derivar do estudo das margens de comercialização é a análise da eficiência dos mercados na cadeia produtiva do produto.

Para Junqueira et al. (1971), o custo de comercialização nos anos 60 era onerado pelas transações horizontais, principalmente as de atacadistas para atacadistas - atacadistas do interior vendiam para atacadistas de maior porte, que, por sua vez, revendiam para outros atacadistas de menor 
porte. Os atacadistas têm uma política de margem que combina uma quantidade fixa e uma percentagem fixa sobre o preço pago aos produtores.

No trabalho de Barros \& Martines Filho (1990), para as margens de comercialização de feijão foram encontrados os resultados apresentados nas Tabelas 4 e 5. A margem do varejista situa-se entre $20 \%$ a $30 \%$, e a do atacadista entre 3\% a 18\% em relação ao produtor paulista e, entre 10 a 44\%, em relação ao produtor paranaense.

Tabela 4. Margem percentual mensal e anual do varejo.

\begin{tabular}{ccccc}
\hline Margem & Período & Mínima & Máxima & Defasagem \\
\hline \multirow{2}{*}{ Percentual mensal do varejo } & \multirow{2}{*}{$1975-84$} & 16,44 & 30,77 & 1 \\
& & 17,67 & 28,76 & 0 \\
\hline \multirow{2}{*}{ Percentual anual do varejo } & \multirow{2}{*}{$1976-84$} & 19,31 & 31,28 & 0 \\
& & 13,65 & 31,02 & 1 \\
\hline
\end{tabular}

Fonte: Barros \& Martines Filho (1990), adaptados pelo autor.

Tabela 5. Margem anual percentual do atacado, no período de 1976-84.

\begin{tabular}{lccc}
\hline \multicolumn{1}{c}{ Local } & Mínima & Máxima & Defasagem \\
\hline Sorocaba & 3,83 & 13,93 & 0 \\
Campinas & $-6,37$ & 11,83 & 0 \\
Campinas & $-16,14$ & 24,85 & 3 \\
Paraná & 18,97 & 27,91 & 0 \\
Paraná & 5,89 & 45,38 & 3 \\
\hline
\end{tabular}

Fonte: Barros \& Martines Filho (1990).

Noutro estudo, realizado por Aguiar et al. (1994), em que abordaram a comercialização de feijão no período de 1980 a 1992, foram 
encontrados os seguintes resultados em relação às margens: a) as margens não aumentaram em termos absolutos e as margens do varejo foram mais altas e instáveis do que as do atacado; c) a participação dos produtores no preço final foi em torno de $63 \%$; d) a margem total absoluta e a margem total relativa eram oscilantes e não apresentavam tendência visível; e) a média da margem total relativa flutuava em torno de $36,7 \%$ e, no ano de 1989 , durante o congelamento de preços; chegou a ficar negativa; f) a margem dos varejistas é substancialmente maior que a dos atacadistas; g) a margem dos atacadistas é estável, enquanto a dos varejistas é mais flutuante. Os autores comparam os resultados de suas pesquisas com os valores encontrados por Junqueira et al. (1968), que estimaram margem de comercialização para os anos 1950-65, e concluíram que os resultados eram semelhantes.

A reduzida margem atacadista do feijão sugere um comportamento semelhante ao modelo de mercado contestável ${ }^{19}$ (Aguiar et al. 1994). Desta forma, a manutenção da lucratividade dos atacadistas era garantida pelo elevado volume transacionado por agente (economia de escala) e não por preços muito acima dos custos.

No trabalho de Tsunechiro et al. (1996), esses pesquisadores afirmam existir três causas básicas que explicam margens de comercialização altas e rígidas: imperfeição de mercado, ignorância comercial e isolamento geográfico dos produtores e intermediários redundantes. Mas neste trabalho não apresentaram conclusão sobre a magnitude dos valores encontrados na revisão que fizeram. Argumentam que, na atividade de comercialização do feijão, não se conhece como cada segmento contribui e qual o custo das atividades desenvolvidas. Desta forma, sugerem que as margens devem ser interpretadas como mero indicador de prováveis ineficiências no sistema. 
Spers \& Nassar (1998) concluíram que as estratégias de baixas margens e transações com baixas quantidades podem ser explicadas pela dispersão da produção, que leva os agentes processadores e distribuidores a se abastecerem em diferentes locais, visando a ganhos em escala. Outros motivos seriam a regularidade de oferta e a perecibilidade que estão associadas aos níveis de exigências dos consumidores finais. Apresentam, também, como falha nos cálculos das margens a não consideração dos prazos e formas de pagamentos.

Segundo Barros \& Martines Filho (1990), as margens de comercialização espelham o volume ofertado pelos produtores, ou seja, sua evolução estacional pode estar relacionada com períodos de safra e entressafra. Isso porque, normalmente, no período de safra ocorre um aumento das margens e uma redução no período de entressafra. Segundo Aguiar (1994), a margem de comercialização é um indicador imperfeito, e chama atenção da necessidade de se ter cuidado na interpretação de seu comportamento. Outras questões relevantes quanto as margens de comercialização do feijão são: o mercado de feijão oferece riscos, em decorrência da perda de qualidade que esse produto sofre durante 0 armazenamento; a dispersão geográfica e temporal de sua produção; suas exigências agroclimáticas; e a hipótese que o risco de comercialização tenha peso significativo em sua margem.

\subsubsection{Causalidade e transmissão de preços}

Burnquist (1986) encontrou que, para o período de 1972 a 1980 e 1972 a 1985, o sentido da causalidade do mercado de feijão, na cidade de São Paulo, era do atacado para o varejo e, no período de 1981 a 1985, era bidirecional. Portanto, a causalidade pode variar conforme o período

${ }^{19}$ Lembramos que neste tipo de mercado o que determina a margem de lucro é a facilidade ou não de entrada de concorrentes potenciais e não o nível de concentração de mercado (Barros, 2000). 
selecionado. Outras conclusões foram: que o sentido da causalidade entre os preços de mercados agrícolas não está relacionada com a estrutura de mercado, mas com choques; que em período unidirecional, os choques da oferta agrícola tendem a predominar sobre os choques de demanda. Conclui ainda: que outros fatores ${ }^{20}$, que não a oferta e a demanda, são os responsáveis pela ausência de causalidade; e que em períodos com sentido bidirecional, ocorrem interações entre oferta e demanda. Ainda com relação ao feijão, verificou que o período de tempo necessário para eliminação de choques ao varejo e atacado era prolongado e que valor encontrado praticamente não variou nos períodos considerados no estudo (Tabela 6).

Tabela 6. Transmissão de preços entre o mercado atacadista e varejista de São Paulo.

\begin{tabular}{cccc}
\hline Sentido & Período & Ajuste total (\%) & Ajuste Imediato (\%) \\
\hline Atacado - varejo & $1972-1980$ & 7,10 & 3,85 \\
Atacado - varejo & $1972-1985$ & 7,34 & 4,47 \\
\hline
\end{tabular}

Fonte: Burnquist (1986), adaptada pelo autor.

De acordo com Aguiar (1990), se o produto for perecível, a tendência será de transmissão mais intensa de decréscimo de preços, porque a dificuldade de manter a qualidade do produto, caso as vendas diminuam, torna inviável a transmissão de acréscimos excessivos.

Barros \& Martines Filho (1990) analisaram a comercialização do feijão no período de 1974 a 1984. Quanto ao sentido da causalidade, o estudo mostrou que os preços ao atacado têm comportamento exógeno, tanto em relação aos preços no varejo quanto aos preços ao produtor. Destacaram também o papel de liderança desempenhado pelo comércio da bolsinha por

${ }^{20}$ Por exemplo, custos de insumos. 
ocasião das variações de preços. Na transmissão de preços não encontraram evidências de que o setor de intermediação amplie os choques de preços, quer seja em nível de demanda ou em nível da produção. Em raras situações os efeitos de choques de mercado se fazem sentir na sua plenitude de imediato. Em geral, observaram que havia um certo lapso de tempo entre o choque e seu efeito total nos demais níveis de mercado. Na Tabela 7 visualiza-se as alterações de $10 \%$ iniciadas em diferentes níveis do mercado e seu impacto noutro nível.

Tabela 7. Transmissão de preços entre preços em diferentes níveis de mercado.

\begin{tabular}{lcccc}
\hline \multicolumn{1}{c}{ Sentido } & $\begin{array}{c}\text { Valor de } \\
\text { referência } \\
(\%)\end{array}$ & $\begin{array}{c}\text { Ajuste } \\
\text { Total } \\
(\%)\end{array}$ & $\begin{array}{c}\text { Ajuste } \\
\text { Imediato } \\
(\%)\end{array}$ & $\begin{array}{c}\text { Ajuste } \\
\text { defasado } \\
(\%)\end{array}$ \\
\hline Atacado - varejo & 10 & 8,89 & 5,39 & 3,50 \\
Atacado - produtor (PR) & 10 & 7,42 & 3,65 & 3,77 \\
Atacado - produtor (SP) & 10 & 9,49 & 6,76 & 2,73 \\
Produtor - atacado & 10 & 8,09 & 8,09 & 0,00 \\
\hline
\end{tabular}

Fonte: Barros \& Martines Filho (1990).

Portanto, para Barros \& Martines Filho (1990), o setor de intermediação possui uma característica desejável de amortecer e distribuir o repasse de preços num período mais elástico, ou seja, os choques não são repassados de forma proporcional. Outrossim, verificaram que existe um lapso de tempo entre o efeito inicial e o efeito total dos choques de preços, porém este período é curto, pois parte substancial desses efeitos é transmitida entre um a três meses. Conseqüentemente, as margens de comercialização tendem a ser mais estáveis. 
Aguiar et al. (1994) também constataram que a transmissão de preços ocorre rapidamente entre o atacado e os demais níveis, sugerindo um funcionamento adequado do mercado. Quanto ao fato das elasticidades de transmissão de preços serem menores do que a unidade, ratifica os resultados encontrados por Barros \& Martines Filho (1990) apontando que eventuais choques de preços tendem a não ser acentuados pelos sistemas de comercialização de feijão (Tabela 8). Ao estudarem as defasagens significativas, considerando os três níveis de mercado, concluíram que apenas as variações instantâneas, no mesmo mês, do preço do atacado afetam o preço recebido pelo produtor e que as variações instantâneas e do mês anterior do preço do atacado afetam o preço no varejo. Esta constatação mostra que as informações fluem rapidamente entre $o$ atacado e os demais níveis desse mercado.

Tabela 8. Transmissão de preços entre preços em diferentes níveis de mercado.

\begin{tabular}{lcccc}
\hline \multicolumn{1}{c}{ Sentido } & $\begin{array}{c}\text { Valor de } \\
\text { Referência (\%) }\end{array}$ & $\begin{array}{c}\text { Ajuste } \\
\text { Total (\%) }\end{array}$ & $\begin{array}{c}\text { Ajuste } \\
\text { Imediato (\%) }\end{array}$ & $\begin{array}{c}\text { Ajuste } \\
\text { defasado(\%) }\end{array}$ \\
\hline Atacado - produtor & 10 & 9,81 & 9,81 & \\
Atacado - varejo & 10 & 8,97 & 4,69 & 4,10 \\
\hline
\end{tabular}

Fonte: Aguiar et al. (1994).

\subsubsection{Eficiência}

Três características que denotam ineficiência de mercado são: a) quando os preços crescem constantemente; b) quando as margens de comercialização são muito elevadas ou crescentes, desde que não estejam associadas à inclusão de novos serviços e melhoria da qualidade do produto final; c) se existir baixa fluidez das informações de mercado. No primeiro caso, 
porque diminui o bem-estar dos consumidores. Nos dois casos seguintes, porque significa que algum setor está auferindo maiores ganhos, o que, por sua vez, pode significar maior ou menor dispêndio do consumidor, ou pode afetar de forma positiva ou negativa a renda dos produtores. Baseados nestas premissas, Aguiar et al. (1994) fizeram um diagnóstico do sistema de comercialização e da eficiência de mercado do feijão no período de janeiro de 1982 a julho de 1992 e concluíram que não havia sinais de ineficiência nesse mercado.

\subsubsection{Consumo}

No trabalho elaborado por Junqueira et al. (1971), para a década de 60, foram estimados os seguintes níveis de consumo per capita anual, Fortaleza-CE de 27,0kg, Campina Grande-PB 25,3kg, Belo Horizonte - MG 22,6kg, Guanabara 21,7kg, Salvador-BA 20,5 kg, São Paulo-SP 18,5kg, RecifePE 17,4kg e São Luís-MA 16,4kg.

Utilizando dados obtidos pelo Estudo Nacional da Despesa Familiar ENDEF-1974/75 (IBGE, 1978), a Comissão de Financiamento da Produção (1981) desenvolveu um estudo do consumo de feijão no Brasil, considerando o período 1974 a 1975 (Tabela 9). Concluiu-se que o consumo metropolitano per capita foi de $16,5 \mathrm{~kg}$ e o consumo rural, quase o dobro, $32 \mathrm{~kg}$. Além disso, verificou-se que cerca de $40 \%$ do consumo total era de produto não comprado, correspondente à fração do produto que é obtido, principalmente, de produção própria e também de doações dos produtores para familiares, ou, ainda, de escambo por outros tipos de mercadorias com membros da comunidade local. Esse fenômeno, denominado de "auto consumo", teve expressiva participação no consumo total, sendo típico de áreas rurais. Já os centros de consumo urbano, notadamente Rio de Janeiro e São Paulo, dependiam dos excedentes gerados nas regiões produtoras. Esta situação freqüentemente gerava incertezas e dificultava as decisões políticas de abastecimento. Concluíram, 
também, naquela época, que estava ocorrendo queda de consumo, não devido às mudanças estruturais nos hábitos de consumo, mas às restrições impostas pelas safras escassas, preços elevados e suplemento incompleto.

Além disso, concluíram: a) que a estrutura da demanda de feijão tinha-se mantido inalterada em relação às épocas anteriores e que as variações nas quantidades e preços eram decorrentes de variações de oferta; b) que a redução no consumo per capita não era explicada por mudanças estruturais nos hábitos alimentares de consumo, mas por problemas de oferta e preços, embora não tivesse sido possível captar efeito da renda sobre o consumo.

Tabela 9. Consumo estimado total (1000 toneladas) de feijão e per capita (kg/hab/ano) de 1974/75.

\begin{tabular}{lccc|crrr}
\hline \multirow{2}{*}{ Região } & \multicolumn{6}{c}{ Consumo } \\
\cline { 2 - 8 } & \multicolumn{3}{c}{ Per capita } & \multicolumn{4}{c}{ Total } \\
\cline { 2 - 8 } & $\begin{array}{l}\text { Metropo } \\
\text { litano }\end{array}$ & Urbano & Rural & $\begin{array}{c}\text { Metropo } \\
\text { litano }\end{array}$ & Urbano & Rural & Total \\
\hline RJ & 17,57 & 19,19 & 24,68 & 134,40 & 20,20 & 22,70 & 177,40 \\
SP & 16,63 & 17,93 & 27,27 & 149,30 & 116,20 & 94,30 & 359,90 \\
PR, SC, RS & 13,35 & 15,82 & 27,83 & 34,40 & 88,20 & 269,90 & 392,50 \\
MG, ES & 15,38 & 20,41 & 33,42 & 28,10 & 106,50 & 215,60 & 350,30 \\
Região* & 18,04 & 21,97 & 38,25 & 79,30 & 189,60 & 660,00 & 929,00 \\
DF & - & 19,21 & - & - & 12,82 & - & 12,82 \\
Região** & 10,52 & 15,32 & 22,64 & 7,60 & 50,00 & 116,10 & 173,80 \\
Total (Brasil) & 16,56 & 19,31 & 32,12 & 433,30 & 583,80 & 1378,8 & 2395,9 \\
\hline
\end{tabular}

Fonte: Comissão de Financiamento da Produção (1981).

Região* $=\mathrm{MA}, \mathrm{PI}, \mathrm{CE}, \mathrm{RN}, \mathrm{PB}, \mathrm{PE}, \mathrm{AL}, \mathrm{SE}, \mathrm{BA}$

Região** $=$ GO, MS, MT, PA, AM, AC, RO, RR, AP

Hoffmann (1995) relata que o consumo per capita médio da população urbana era $70 \%$ menor do que das pessoas residentes no meio rural 
e que a população rural, em relação à população total do País, passou de 44,1\% em 1970 para 24,5\% em 1991. Segundo o autor, somente essa estatística seria capaz de justificar um decréscimo de $7 \%$ no consumo médio de feijão. Considerou, ainda, que, entre meados da década de 70 e fim dos anos 80, a disponibilidade de feijão para o consumo humano no Brasil diminuiu de 13 para 11 kg/habitante/ano, caracterizando uma redução de 12 ou 15\%. Desta forma, o processo de urbanização explicaria mais da metade da redução no consumo neste período.

De acordo com Martins (1998), no período entre as pesquisas do ENDEF-1974/75 (IBGE, 1978) e POF-1987/88 (IBGE,1991), ocorreu uma redução de cerca de $10 \%$ nos preços do feijão e que, apesar desta redução, o consumo per capita de feijão diminuiu em torno de $30 \%$. Os dados do ENDEF1974/75 (IBGE, 1978) indicaram um consumo médio de feijão nas metrópoles de 16,56 kg/hab/ano, a POF-1987/88 (IBGE,1991) de 11,77 kg/habitante/ano. Em termos monetários, a redução nas despesas com o produto foi de $41,2 \%$ (os valores médios anuais per capita gastos em 74/75 e 87/88, atualizados para janeiro de 2000, seriam, respectivamente, $R \$ 41,56$ e $R \$ 24,40)$. Assim, o autor conclui que a redução no consumo de feijão foi devida à mudança no hábito alimentar e não ao fator preço, afirmando que a renda per capita explica apenas pequena parcela da variação.

Comparando os dados da POF-1995/96 (IBGE,1998), que informa que o consumo per capita de feijão nas metrópoles brasileiras foi de 10,19 kg/habitante/ano com a POF-87/88, observa-se que ocorreu uma redução de 1,58 kg/habitante/ano. No período entre o ENDEF-1974/75 (IBGE,1978) e a primeira POF-1987/88 (IBGE, 1991), o consumo caiu 4,79kg/habitante/ano. Outras variáveis impedem-nos de concluir que na última década houve uma reversão na tendência de redução de consumo, pois o levantamento da POF 
1996/97, foi realizado num período sob influência do Plano Real, que apresentou um crescimento atípico do consumo.

$\mathrm{Na}$ Tabela 10 vê-se as taxas de crescimento per capita para diferentes períodos, obtidas por diferentes metodologias. Os resultados identificados por um asterisco são resultantes de cálculos utilizando a média móvel de três anos; os resultados identificados por dois asteriscos foram obtidos com o cálculo feito pela média da década. Utilizando os resultados do primeiro método, encontra-se uma taxa de crescimento positiva para o consumo per capita de feijão nas décadas de 60 a 90.0 s resultados do segundo método mostram que entre as décadas de 60 e 70, 70 e 80, as taxas foram negativas, e entre 80 e 90 , positiva. O consumo na década de 90, conforme mostrou a Tabela 3, foi acima da média nos anos de 1994 a 1996, depois voltou a cair. Portanto, o nesta década a tendência de consumo foi alterada. Porém, considerando que esta quebra de comportamento foi sob a influência do Plano Real, pois os efeitos não foram permanentes, ou seja, há indícios que o consumo voltou a cair para níveis observados nas décadas anteriores.

Ferreira \& Yokoyama (1999) realizaram uma pesquisa, no período de novembro a dezembro de 1996, com consumidores de feijão nas capitais dos Estados da Região Centro-Oeste, e encontraram que o consumo per capita médio mensal de feijão, foi cerca de $34 \%$ maior nas classes de renda mais baixas, quando comparado com as classes de renda acima de dez salários mínimos. Isto significa que o consumo per capita mensal de feijão das classes mais ricas é cerca de 0,4 quilos menor do que o das classes de menor renda. Neste trabalho, cerca de $85 \%$ dos consumidores responderam que manteriam o mesmo consumo de feijão, mesmo se ocorresse um aumento do preço do produto. 
Tabela 10. Taxas de crescimento do suprimento, consumo de feijão e da população do Brasil nas décadas de 60,70, 80 e 90.

\begin{tabular}{|c|c|c|c|c|c|}
\hline \multirow{3}{*}{ Décadas } & \multicolumn{5}{|c|}{ Taxa de crescimento } \\
\hline & \multirow{2}{*}{$\begin{array}{c}\text { Suprimento } \\
\text { Total }\end{array}$} & \multicolumn{3}{|c|}{ Consumo } & \multirow{2}{*}{$\begin{array}{l}\text { População } \\
\text { do Brasil }\end{array}$} \\
\hline & & Aparente & Total & per capita & \\
\hline $60^{*}$ & 1,32 & 1,38 & 1,38 & 1,12 & 1,24 \\
\hline $70^{*}$ & 0,93 & 0,88 & 0,90 & 0,75 & 1,18 \\
\hline $80^{*}$ & 0,93 & 1,02 & 1,01 & 0,88 & 1,15 \\
\hline $90^{*}$ & 1,03 & 1,02 & 1,01 & 1,01 & 1,15 \\
\hline $60 / 70^{* *}$ & 1,10 & 1,10 & 1,12 & 0,86 & 1,30 \\
\hline $70 / 80^{* *}$ & 1,01 & 1,03 & 1,05 & 0,82 & 1,25 \\
\hline $80 / 90^{\star *}$ & 1,18 & 1,21 & 1,19 & 1,02 & 1,18 \\
\hline
\end{tabular}

Fonte: Levantamento Sistemático da Produção Agrícola. IBGE, (1990...). IBGE (1996), adaptado pelo autor.

* = resultantes de cálculos utilizando a média móvel de três anos;

** $=$ os resultados obtidos com o cálculo feito pela média da década

Os trabalhos são unânimes em assumir a queda do consumo per capita de feijão no Brasil. Porém, a magnitude desta redução não está bem dimensionada, não havendo, entretanto, consenso sobre as suas causas. A opinião de que as variáveis preço e renda não são as principais influenciadoras no comportamento dos consumidores tem sido referida pela quase totalidade dos pesquisadores.

\subsubsection{Projeção de consumo}

A falta de dados e informações sistemáticas sobre o consumo de feijão dificulta um estudo de sua projeção. Este é um desafio que, com freqüência, é enfrentado nos estudos que abordam aspectos de mercado e 
comercialização. Por exemplo, a Comissão de Financiamento da Produção (1981) fez uma projeção de demanda de feijão para o período de 1978 a 1981 (Tabela 11). No modelo utilizado, foram testados vários produtos e o que se mostrou como substituto do feijão foi o trigo. Assim, a projeção foi feita utilizando como variáveis o preço do feijão, o preço do trigo, a renda, o salário urbano, a taxa de urbanização. As quantidades projetadas ficaram cerca de $10 \%$ superiores às efetivamente observadas. Os $R^{2}$ das equações ficaram em torno de 0,70 , demonstrando que $30 \%$ do consumo não era explicado pelo modelo.

Tabela 11. Dados estimados e projeção sobre consumo total (1000 toneladas) e per capita (kg/habitante/ano) de feijão de 1978 a 1981.

\begin{tabular}{ccc|cc}
\hline \multirow{2}{*}{ Ano } & \multicolumn{4}{c}{ Consumo } \\
\cline { 2 - 5 } & per capita (kg/habitante/ano) & \multicolumn{2}{c}{ Total (1000 toneladas) } \\
\cline { 2 - 5 } & Previsão & Observada & Previsão & Observada \\
\hline 1978 & 18,45 & 18,10 & 2086,40 & 2297,60 \\
1979 & 16,93 & 16,80 & 1959,10 & 2213,50 \\
1980 & 14,18 & 13,60 & 1716,90 & 1895,60 \\
1981 & 17,57 & 17,40 & 2127,40 & 2433,20 \\
\hline
\end{tabular}

Fonte: Comissão de Financiamento da Produção (1981), Levantamento Sistemático da Produção Agrícola. IBGE, (1990...), adaptado pelo autor.

Um estudo coordenado por Vieira (1994) projetou o consumo de vários produtos para o período de 1992 a 1995 (Tabela 12). Foram utilizadas como variáveis as taxas de crescimento da população residente e da renda interna bruta. A base da projeção em nível estadual foram os dados da Pesquisa de Orçamento Familiar - POF - 1987/88. 
Tabela 12. Projeção do consumo interno per capita ( $\mathrm{kg} / \mathrm{habitante/ano)} \mathrm{e}$ consumo total aparente (1000 toneladas) de feijão no período de 1992 a 1995.

\begin{tabular}{ccc|cc}
\hline \multirow{2}{*}{ Ano } & \multicolumn{4}{c}{ Consumo } \\
\cline { 2 - 5 } & \multicolumn{2}{c}{ per capita (kg/habitante/ano) } & \multicolumn{2}{c}{ Total (1000 toneladas) } \\
\cline { 2 - 5 } & Previsão & Observada & Previsão & Observada \\
\hline 1992 & 17,18 & 16,66 & 2685,00 & 2489,20 \\
1993 & 17,03 & 16,94 & 2712,00 & 2568,20 \\
1994 & 16,74 & 18,65 & 2715,00 & 2867,70 \\
1995 & 16,45 & 18,86 & 2716,00 & 2939,20 \\
\hline
\end{tabular}

Fonte: Vieira (1994).

\subsection{Enfoque e metodologia utilizada nos estudos e relacionamento entre estes e o presente trabalho}

Junqueira et al. (1971) fizeram uma pesquisa ampla para abordar aspectos da produção e comercialização do feijão na década de 60 . Abordaram questões relacionadas a fluxos, preços relativos e outros. Tinham como objetivo principal estudar o comportamento de questões relacionadas com fluxos, preços relativos e abastecimento no Estado de São Paulo. Neste trabalho, praticamente não utilizaram instrumentos econométricos e nem consideraram aspectos de política econômica. Outra característica deste estudo e de outros que abordaram os anos 60 e início dos 70 é a preocupação em considerar o consumo na própria região produtora, ou seja, contabilizar somente o excedente para o abastecimento de outros mercados, fato que, nos trabalhos mais recentes, tem sido desprezado.

Burnquist (1986) utilizou técnicas econométricas para determinar o sentido da causalidade e transmissão de preços nos mercado de feijão. Nos 
estudos mais recentes como, por exemplo, o de Barros \& Martines Filho (1990), a abordagem é centrada em alguns aspectos da cadeia produtiva, tendo como principal objetivo fornecer subsídios para políticas, através do levantamento dos maiores problemas que afetavam o comportamento dos preços. Naquela época, o Governo vinha freqüentemente intervindo na economia, tentando controlar a inflação. Aguiar (1994) trabalha praticamente com os mesmos instrumentos utilizados por Barros \& Martines Filho (1990), porém muda o foco, uma vez que o problema não era mais a inflação, mas a competitividade. Nestes dois últimos trabalhos, foram utilizados procedimentos econométricos. Spers \& Nassar (1998) mantêm o enfoque de Aguiar (1994), porém voltam à abordagem ampla de cadeias produtivas e também não utilizam procedimentos econométricos. Suas conclusões são tiradas, principalmente, em contatos e pesquisas com atores da cadeia.

Quanto aos trabalhos de projeção de demanda, nota-se que o feito pela Comissão de Financiamento da Produção (1981) preocupou-se em encontrar produtos substitutos do feijão na alimentação. O estudo de Viera (1994) preocupou-se com a elasticidade renda consumo, renda disponível e crescimento da população. Comparando os resultados destes dois estudos, nota-se que não divergiram muito do consumo real, apesar de usarem metodologias bem diferenciadas. Ou seja, para fazer projeção para curtos períodos, os dois princípios são capazes de apresentar resultados satisfatórios.

Os conceitos que serão utilizados no presente trabalho são praticamente os mesmos utilizados nos estudos anteriores, o que muda é o período abordado, os objetivos propostos e a metodologia utilizada, pois recentemente vários procedimentos econométricos foram introduzidos, tanto nos modelos quanto no tratamento das séries temporais. Assim, aplica-se simultaneamente o teste de raiz unitária nas séries temporais, o teste de causalidade e utiliza modelos que avaliam a transmissão de preços. Ademais, 
tem a preocupação de buscar uma visão mais ampla da cadeia para avaliar a produção e comercialização de feijão. Outra inovação no trabalho é a utilização da estimativa da quantidade de feijão colhida mensalmente. 


\section{METODOLOGIA}

O objetivo deste capítulo é mostrar de que forma o problema será analisado. Neste sentido, apresentam-se e discutem-se os tratamentos realizados com as variáveis e explicam-se os modelos econométrico e teórico. Outro propósito é justificar os procedimentos utilizados.

Para alcançar os objetivos a metodologia proposta é a seguinte: a) levantamento e tratamento dos dados; b) estudos sobre produção, considerando época e distribuição geográfica, principais fluxos; c) algumas relações entre os preços recebidos pelos produtores dos sete principais Estados produtores e entre os preços ao atacado e varejo na cidade de São Paulo; d) cálculo das margens; e) estudos econométricos; f) modelo econômico para cálculo da elasticidade de transmissão de preços, g) projeção de consumo.

\subsection{Levantamento e tratamento dos dados}

Basicamente, o estudo demandou informações sobre quantidades, épocas e localização da produção e preços nos diferentes níveis de mercado. A partir destes, foi gerada uma série de outras informações, o que será mostrado a seguir.

Diante das críticas do sistema de quantificar a oferta de feijão baseado-se em resultados das grandes safras, o presente trabalho se propôs a calcular a oferta mensal por Estado, no período de 1990 a 1999. As dificuldades para fazer este cálculo foram inúmeras, pois em função da falta de estatísticas foram elaborados questionários e enviados a várias instituições a nível Estadual 
e Federal, mas a taxa de retorno foi muito baixo. O resultado final foi obtido utilizando dados divulgados no Boletim Previsão de Safras da Companhia Nacional de Abastecimento - Conab (Brasil, 1991...). Neste informativo existe previsão do índice de colheita nos Estado do Sul e Bahia. A terceira safra não é levantada. A outra fonte consultada foram os Censos Agropecuários, que apresentam as quantidades colhidas mensalmente, mas somente nos anos que foram realizados os censos. Estes dados foram complementados com as poucas informações obtidas nas instituições de pesquisa ou extensão de vários Estados. A maioria foi informação pessoal.

Realizando os procedimentos descritos no parágrafo anterior, obteve-se um percentual médio da quantidade colhida mensalmente, que por sua vez foi relacionado com os dados da produção de safra, estimando-se assim a quantidade aproximada da real produção ofertada mensal. Esta informação permitiu mapear os Estados produtores mais importantes e suas principais épocas de colheitas, bem como possibilitou fazer estudos das relações entre as produções dos Estados. Permitiu também identificar os principais fluxos de comercialização durante o ano. Como a oferta total é constituída da produção interna e das importações, também foram levantados dados das importações.

Para caracterizar a abrangência geográfica da produção em microrregiões, utilizou-se dados da Produção Agrícola Municipal - PAM (IBGE, 1990 ...). Desta forma, foram consideradas as produções anuais de feijão de mais de cinco mil municípios do Brasil, no período de1990 a 1996. Para facilitar as análises, as produções foram agrupadas em 552 microrregiões. Assim também, identificaram-se as principais microrregiões em relação à produção de feijão (Tabelas A14 a A19, anexo).

Posteriormente foram levantados os preços médios recebidos pelos produtores dos Estados nas seguintes fontes: O preço do Rio Grande do Sul foi a 
média dos preços fornecidos pela Conab ${ }^{21}$ e Empresa de Assistência Técnica e Assistência Rural - Emater-RS ${ }^{22}$; para São Paulo, foi a média de preços da Conab e Informações Econômicas (1990...); para o Paraná, a média da Conab e Departamento de Economia Rural - Deral, da Secretaria de Agricultura do Paraná (Paraná, 1990...); para Santa Catarina, Minas Gerais, Goiás e Bahia, foram os preços da Conab. Também foram levantados os preços nos mercados atacadista e varejista da cidade de São Paulo. Todas as séries de preços utilizadas no trabalho foram corrigidas para valores em real de janeiro de 2000.

Neste trabalho, utilizam-se os preços ao varejo e atacado da cidade de São Paulo, porque é o principal centro consumidor de feijão, e também é nela que se concentra parte considerável do mercado atacadista deste produto. De acordo com Santiago et al. (2000), apesar da perda de importância, esse canal de comercialização ${ }^{23}$ ainda desempenha seu papel na distribuição de feijão. No fim da década de 90, havia cerca de 230 estabelecimentos que costumeiramente comercializavam feijão, movimentando, em média, 105 toneladas/dia. Outra justificativa para utilizar-se o preço do varejo da cidade de São Paulo foi a análise de correlação entre os preços mensais do varejo da cidade dessa cidade e o preço médio mensal do varejo nas demais metrópoles. O resultado mostrou 99,9\% de correlação contemporânea, taxa bastante alta. Ou seja, os preços no varejo se modificam simultaneamente, independente da região consumidora.

${ }^{21}$ Dados de publicação eletrônica, recebidos por e-mail

22 Dados de publicação eletrônica, recebidos por e-mail

${ }^{23}$ Estes autores comentam que, dentre vários fatores que contribuíram para o surgimento de um novo tipo de articulação entre as diferentes etapas das cadeias produtivas, de forma geral, não especificamente só para o feijão, podem-se destacar: a) impacto da informática; b) aumento do tamanho dos compradores e vendedores, c) melhores informações de mercado, possibilitando realizar transações à distância sem a presença de contato pessoal, d) segurança de fornecimento regular; e) crescimento do atacado distribuidor de indústrias. 
Os preços ao atacado na cidade de São Paulo foram obtidos no periódico Informações Econômicas (1990...). Neste caso, o valor utilizado corresponde ao feijão carioca do tipo 1. Foi escolhido este preço porque, segundo Spers \& Nassar (1998), cerca de $71 \%$ do volume de feijão comercializado no Brasil $^{24}$ se enquadram neste tipo e, certamente, a maior parte consumida se classifica como tipo 1. A fonte dos preços no varejo foi a pesquisa da cesta básica (Departamento Intersindical de Estatística e Estudos Sócio-econômicos, 1990...) Os preços no varejo correspondem ao preço do feijão carioca.

Foram efetuadas algumas análises preliminares como: relação entre os preços médios recebidos pelos produtores dos Estados do Rio Grande do Sul, Santa Catarina, Paraná, São Paulo, Minas Gerias, Goiás e Bahia; relações dos preços médios mensais do atacado e varejo da cidade de São Paulo; cálculo do comportamento e tendência polinomial dos preços médios recebidos pelos produtores.

\subsection{Estudo das margens de comercialização}

Para calcular a margem de comercialização não basta fazer uma simples operação de subtração do preço de varejo e o preço pago ao produtor; é necessário rastrear o caminho percorrido pela matéria-prima até o consumidor final, ou seja, conhecer a origem, as transações entre intermediários, o tempo de armazenamento e, ainda, as unidades equivalentes entre níveis de mercado ${ }^{25}$. No caso do feijão, é praticamente impossível determinar com

\footnotetext{
${ }_{25}^{24}$ Seguido pelo feijão preto com, $19 \%$, pelo caupi, $8 \%$ e outros tipos, $2 \%$.

${ }^{25}$ No caminho percorrido pelos produtos agrícola da unidade de produção até o consumidor final podem ocorrer perdas ou geração de subprodutos. Desta forma, a quantidade do produto que sai num determinado nível de mercado pode não ser igual a que entrou. A correção destas quantidades para fins comparativos é feita usando o conceito de unidades equivalentes.
} 
exatidão estes parâmetros, haja vista, por exemplo, que, em maior ou menor quantidade, o mercado paulista recebe mercadorias de vários Estados e regiões durante o ano todo. Quanto ao aspecto de unidades equivalentes, as perdas variam bastante com a época, origem, tempo de armazenamento, condições climáticas na época da colheita e outros fatores. Desta forma, no cálculo das margens, não foram consideradas as unidades equivalentes. Alguns autores como Aguiar et al. (1994), consideram que estas perdas são significativas, mas Ferreira (2001) encontrou que a perda máxima tolerada pelos grandes atacadista é de $6 \%$. De qualquer forma, como não foi considerada nenhuma perda, os valores das margens estão supervalorizados.

Neste estudo foram calculadas a margem total (MT) eq (1), margem total relativa (MTr), eq (2), margem absoluta do varejo (Mv), eq (3), margem relativa do varejo (Mvr), eq (4) margem absoluta do atacado (Ma), eq (5) e margem relativa do atacado (Mar), eq (6).

$$
\begin{aligned}
& M T=P v-P p \\
& M T r=\frac{(P v-P p)}{P v} \\
& M v=P v-P a \\
& M v r=\frac{(P v-P a)}{P v} \\
& M a=P a-P p \\
& M a r=\frac{(P a-P p)}{P v}
\end{aligned}
$$


onde

$\mathrm{PV}=$ preço varejo

$\mathrm{Pp}=$ preço pago ao produtor pela quantidade equivalente na fazenda

$\mathrm{Pa}=$ preço no atacado a quantidade equivalente à unidade vendida no varejo

Após o cálculo das margens, foram feitas análises confrontando os resultados com os volumes produzidos e com o acontecimento políticoeconômico referencial no trabalho - o Plano Real.

\subsection{Estudos econométricos ${ }^{26}$}

O procedimento seguinte foi realizar os estudos econométricos das variáveis. A metodologia básica aplicada consiste de duas etapas. A primeira, identificar o sentido da causalidade, ou seja, diante de algum fator ou choque, verificar em que nível de mercado mais freqüentemente se iniciam as alterações de preços. A segunda, observar como essas alterações são transmitidas, ou com que intensidade os níveis de mercado reagem frente aos choques. Esta metodologia tem sido amplamente aplicada, foi utilizada por Guimarães (1990), Bliska (1989), Alves (1996), Barros \& Martines Filho (1990), Aguiar et al. (1994), entre outros autores.

Antes de iniciar os procedimentos descritos no parágrafo anterior, foi feito o teste para detectar a presença de raiz unitária nas séries econômicas utilizadas no trabalho. A aplicação deste procedimento em séries geradas por processos estocásticos independentes tornou-se obrigatória a partir do trabalho de Granger \& Newbold (1974), que demonstraram a

${ }^{26}$ Os procedimentos econométricos foram realizados através do software RATS (Doan \& Litterman, 1987). 
existência de regressões espúrias na presença de séries não estacionárias ${ }^{27}$. Isto é, as regressões podem não apresentar significado econômico, mesmo apontando testes " $t$ " e coeficiente de determinação $\left(R^{2}\right)$ significativos.

Neste sentido, primeiramente, para determinar o número de defasagens, foram realizados os teste de Akaike (Akaike information criterionAIC) e Schwarz (Schwarz criterion-SC). Como segundo passo, com a finalidade de investigar a existência de uma relação de equilíbrio de longo prazo entre duas séries temporais, foi realizado o teste de co-integração. $\mathrm{Na}$ etapa seguinte, foram realizados testes de correlação, para verificar o grau de associação linear entre as variáveis. O teste de exogeneidade, ou causalidade, serve para mostrar em que nível de mercado se verifica um comportamento de liderança. Isto é, em que nível originam os choques. É chamado de teste de exogeneidade por indicar qual a variável é endógena e qual é exógena na equação de transmissão de preços. A aplicação deste teste é contestada, pois, segundo Maia (1996), dentro de uma mesma cadeia produtiva a causalidade poder variar quando se abordam períodos diferentes, propositura de acordo com os resultados encontrados por Burnquist (1986). Apesar desta limitação, este procedimento se faz necessário como suporte empírico para adoção dos modelos.

\subsubsection{Determinação do número de defasagens}

Para determinar o número de defasagens, foram realizados os testes de Akaike (Akaike information criterion- AIC) e Schwarz (Schwarz criterion- SC). As equações são, respectivamente, as de números 7 e 8 . Os resultados encontrados $\left(r_{i}\right)$ no AIC ou SC, foram utilizados nas regressões em nível. Quando os modelos eram defasados uma ou duas vezes, foram utilizados

\footnotetext{
${ }^{27}$ Um processo é dito estacionário quando as médias e variâncias são constantes ao longo do tempo e a covariância só depende do intervalo de tempo e não do tempo para o qual a covariância é computada (Gujarati, 1995).
} 
os valores $z_{11}$ e $z_{i 2}$, obtidos segundo as equações 9 e 10. No caso em que o modelo era defasado e o resultado encontrado pelos testes AIC ou SC era igual à unidade, manteve-se este valor, ou seja, não foi utilizado o princípio de redução do valor descrito para $z_{i 1}$ e $z_{i 2}$.

$$
\begin{aligned}
& A I C=T \log (S Q R)+2 K \\
& S C=T \log (S Q R)+K(\log T)
\end{aligned}
$$

onde

$T$ = número de observações

$\mathrm{SQR}=$ Soma do quadrado do resíduo

$\mathrm{K}=$ número de variáveis independentes

$$
z_{i 1}=r_{i-1}(9) \quad z_{i 2}=r_{i-2}
$$

\subsubsection{Teste de raiz unitária}

O teste utilizado foi o de Dicky-Fuller -1976- mais conhecido como teste de Dickey-Fuller Aumentado (DFA). Este teste consiste em gerar por um processo autoregressivo de ordem $z_{i}$ ou $z_{i 2}\left[A R\left(z_{i}\right.\right.$ ou $\left.\left.z_{i 2}\right)\right]$ um modelo do tipo 11, onde os valores de $z_{1}$ e $z_{2}$ são obtidos pelos testes AIC e SC. Depois, iniciam-se os testes de hipóteses de nulidade $\left(\tau_{\tau}\right),\left(\tau_{\beta \tau}\right)$, $\left(\Phi_{3}\right),\left(\tau_{\mu}\right),\left(\tau_{\alpha \mu}\right),\left(\Phi_{1}\right),(\tau)$. A Figura 4 resume os procedimentos e permite a visualização destes testes. Portanto, estes testes não utilizam a distribuição padrão de "t" de Student mas, sim, valores de distribuição empírica especial (Tabela A1 e A2, anexo). Quando há Indicativo de presença de raiz unitária, ou 
seja, quando a série $u_{t}$ não apresenta "Ruído Branco ${ }^{28 ", ~ r e i n i c i a-s e ~ o ~}$ procedimento, utilizando um modelo do tipo 12. Isto é, aplica-se nova diferença. Estes procedimentos devem ser realizados sucessivamente, até que a série se torne estacionária.

$$
\Delta l \text { variável }(n)=\alpha+\beta T+\partial l_{\text {variável }(n)}+\sum_{t-1}^{z i} \omega_{i} \Delta l \text { variável }(n){ }_{t-z i}+\mu_{t}
$$

$$
\Delta \Delta l \text { variável }(n)=\alpha+\beta \Delta t+\partial \Delta l \text { variável }(n)_{t-1}+\sum_{i=1}^{z_{2 i}} \omega_{i} \Delta \Delta l \text { variável }(n){ }_{t-z_{21}}+\mu_{t}
$$

onde:

variável $(n)=$ variável a ser testada, podendo ser preço recebido pelos produtores, preço no varejo, preço no atacado, produção ou outras;

$\mathrm{T}=$ variável tendência

$\alpha, \beta \partial e \omega_{i},=$ parâmetros da equação

$$
\begin{aligned}
& \Delta=\text { diferença } \\
& \mathrm{I}=\text { logaritmo } \\
& \mathrm{t}-\mathrm{i}=\text { defasagem } \\
& \mu_{t}=\text { erro aleatório }
\end{aligned}
$$

$\mathrm{z}_{\mathrm{i} 1}$ e $\mathrm{z}_{\mathrm{i} 2}=$ número de defasagem calculado por AIC ou SC

\footnotetext{
${ }^{28}$ Ruído Branco: quando o resíduo de uma série com tendência estocástica - não estacionária,
} apresenta média zero e variância constante e não são autocorrelacionados. 
Os resultados encontrados, que serão discutidos posteriormente, mostraram que, com exceção da variável preço ao varejo, as demais séries utilizadas no trabalho apresentam ordem de integração I (1). Por isso, os testes de correlação e causalidade foram realizados aplicando uma diferença, exceto a série preço ao varejo que foi utilizado em nível. 
$\Delta l$ var iável $(n)=\alpha+\beta T+\partial l$ var iável $(n){ }_{t-1}+\sum_{i=1}^{z} \omega_{i} \Delta l$ var iável $(n){ }_{t-z i}+\mu_{t}$

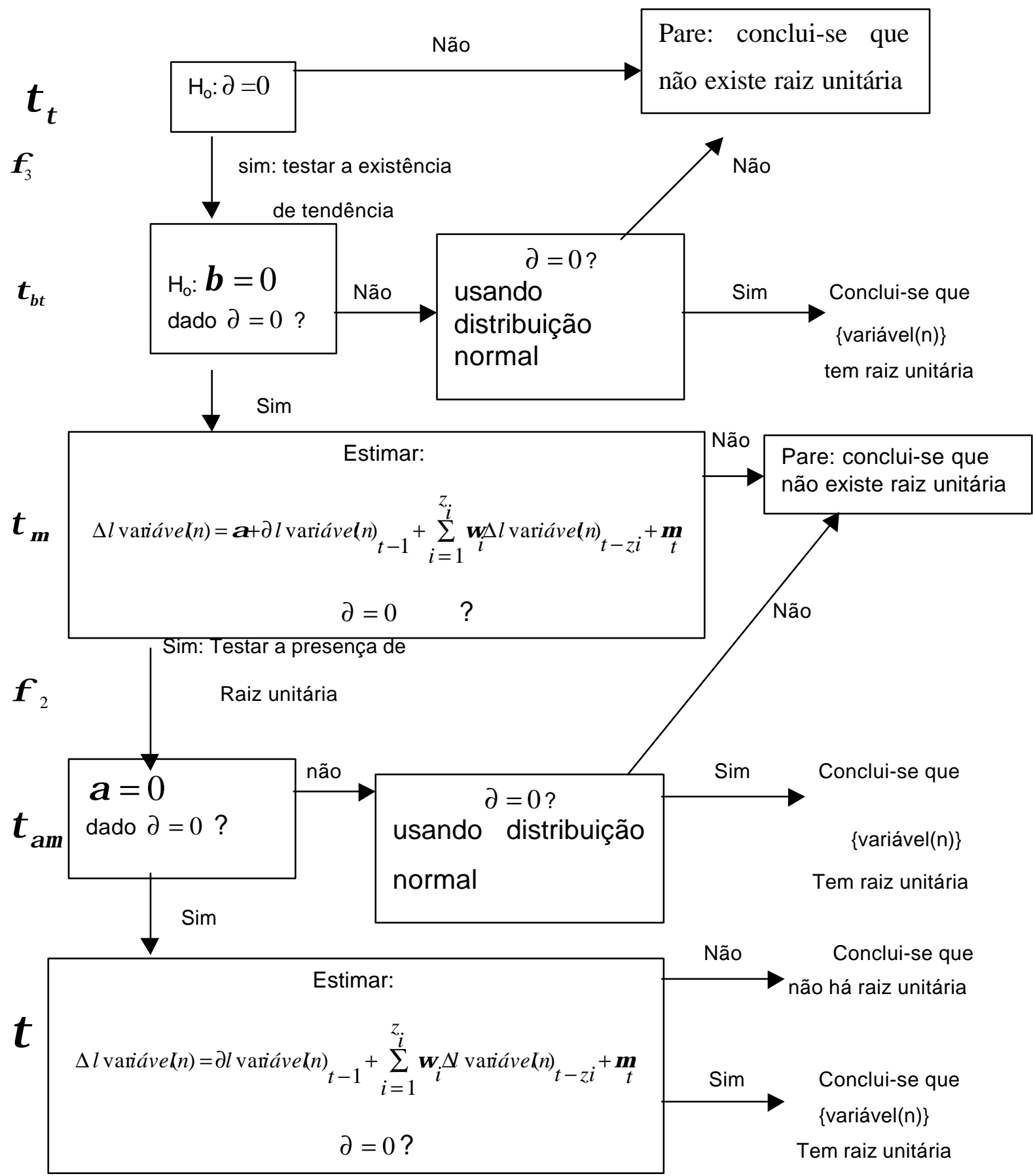

Figura 4 - Procedimento de teste para raiz unitária.

Fonte: Enders (1995) 


\subsubsection{Teste de co-integração}

Além da capacidade de determinar a condição de longo prazo, este teste tem a finalidade de subsidiar a aplicação do modelo de correção do erro, pois quando se trabalha com diferença os modelos apresentam problemas de especificações devido às alterações nas informações de longo prazo. Uma forma de corrigir esse problema é utilizar o termo correção do erro, que será explicado a seguir.

Antes de realizar o teste de co-integração, utilizando equações do tipo 13 e 14, foram gerados os resíduos ${ }_{n k}{ }_{n k} \quad r e s_{k n}$ entre as séries. Nestes resíduos foram feitos os testes AIC e SC para determinar o número de defasagens $h_{n k} e h_{k n}$.

$$
\begin{aligned}
& l \text { variável }(n)=\rho l \text { variável }(k)+r_{n k} \\
& l \operatorname{variável}(k)=\rho l \text { variável }(n)+r_{k n}
\end{aligned}
$$

onde:

variável $(n)$ e variável $(k)$ = variáveis a serem testadas

$\rho=$ parâmetro da equação

I = logaritmo

res $_{n k}$ e res kn $_{\text {= }}$ resíduos das regressões

O teste de co-integração propriamente dito foi feito verificando a presença de raiz unitária nas equações 15 e 16. Neste caso, também se utiliza 
uma Tabela especial com valores críticos para a tomada de decisão (Tabela A3). Quando a resposta era afirmativa, ou seja, quando res $_{n k}$ ou res $s_{k n}$ eram I(1) e a variável(n) ou variável(k) também era I(1), concluía-se que as séries são cointegradas. Conseqüentemente, em caso contrário as séries não são cointegradas.

$$
\begin{gathered}
\Delta r e s_{n k}=r e s_{n k-1}+\sum_{n k=1}^{h_{n k}} \lambda \Delta r e s_{n k} \\
\Delta r e s_{k n}=r e s_{k n-1}+\sum_{k n=1}^{h n} \lambda \Delta r e s_{k n}
\end{gathered}
$$

onde:

res $_{\mathrm{nk}}$ e res $\mathrm{s}_{\mathrm{kn}}=$ são resíduos das regressões 13 e 16

$\Delta$ = diferença

$h_{n k} \quad e \quad h_{k n}=$ número de defasagem determinado pelos testes AIC e SC

\subsubsection{Teste de correlação}

Os testes de correlação foram feitos entre as $\Delta$ variáve(n) e $\Delta$ variávelk) e $\Delta$ variávell $(k)$ e $\Delta$ variável(n). Ambos com zero a doze defasagens. Os resultados $\mathrm{w}_{\mathrm{i}}$ ou $\mathrm{m}_{\mathrm{j}}$ foram utilizados nas defasagens das variáveis independentes no teste de causalidade. Foram considerados significativos os resultados cujo valor do teste "t" calculado eram maiores do que o valor encontrado pela equação 17. 


$$
\frac{2}{\sqrt[2]{n}}
$$

onde

$\mathrm{n}$ = número de observações

\subsubsection{Teste de causalidade}

O teste utilizado foi o proposto por Granger.. Este teste assume que "o futuro não pode causar o passado nem o presente", mas se a variável X causa alterações na variável $Y$, então $X$ precede e/ou é informação relevante para Y. A hipótese básica é que a informação relevante para a predição está contida exclusivamente nas séries de tempo dessas variáveis (Bahia, 2000).

Foram estimadas as regressões do tipo 18 e 19 por Mínimos Quadrados Ordinários - MQO. Nas séries co-integradas, utilizaram-se modelos de correção do erro ${ }^{29}$. Ou seja, foram acrescentados os res nk-1 $_{\text {e res }}$ kn-1 e, nas séries não co-integradas, não foram utilizados. As defasagens para a variável(k) foram calculadas pelo teste de correlação.

$$
\Delta l \text { variável }(n)=\alpha+\beta T+\sum_{t=1}^{w_{i}} \psi \Delta l \text { variável }(k) \underset{t-1}{r_{i}}+\sum_{t=1}^{r_{1}} \Omega \Delta{\text { variável }(n)_{t-i}}_{t}+e_{n k-1}
$$

29 Sendo as séries estacionárias de ordem 1, ou seja I (1), e existindo co-integração, os parâmetros estimados são viesados. O modelo de correção do erro é uma prática para solucionar este problema, porque recupera o desvio da trajetória de longo prazo das variáveis. 
$\Delta$ variável $(k)=\alpha+\beta T+\sum_{t=1}^{m_{i}} \hbar \Delta l$ variável $(n)_{t-1}+\sum_{t=1}^{r} \sigma \Delta l$ variável $(k)_{t-1}+r e s_{k n-1}$

onde:

variável $(n)$ e variável $(k)$ = variáveis a serem testadas;

$\alpha, \beta, \Psi, \Omega \hbar e \partial_{=}$parâmetros da equação

I = logaritmo

res $_{\mathrm{nk}}$ e res $\mathrm{kn}_{\mathrm{kn}}=$ resíduos das regressões 13 e 14

$\mathrm{w}_{\mathrm{i}}$ e $\mathrm{m}_{\mathrm{j}}=$ número de defasagem determinados pelos testes de correlação

$\left(r_{i}\right)=$ número de defasagem encontrado no $\mathrm{AIC}$ ou $\mathrm{SC}^{30}$

O teste de causalidade de Granger consiste em testar as hipóteses de nulidade (20 e 21) dos valores defasados das variáveis independentes (das equações 18 e 19) através do teste F. Neste trabalho foram utilizado o nível de significância de 10\%. Portanto, baseia-se na capacidade de previsibilidade de uma variável a partir da outra.

$$
\psi_{1}=\psi_{2}=\ldots . .=\psi_{w i}=0
$$

${ }^{30}$ Esses testes foram utilizados mesmo sabendo que não específicos para esse teste, mas sua utilização baliza-a duração do efeito da pertubação. 


$$
\hbar_{1}=\hbar_{2}=\ldots . .=\hbar_{m i}=0
$$

A análise do teste pode resultar em uma relação bi-causal quando as hipóteses 20 e 21 são rejeitadas. A não rejeição de ambas indica ausência de causalidade. E a rejeição de somente uma das hipóteses indica causalidade no sentido da não rejeitada para a rejeitada. A Figura 5 apresenta um esquema dos testes econométricos.

\subsection{Estimativa da elasticidade de transmissão de preços}

Finalmente, após a determinação do sentido de causalidade foram estimadas as equações de transmissão de preços nas relações que mostraram causalidade unidirecional. A elasticidade de transmissão de preços mostra o percentual de variação do preço num nível de mercado, quando ocorre 


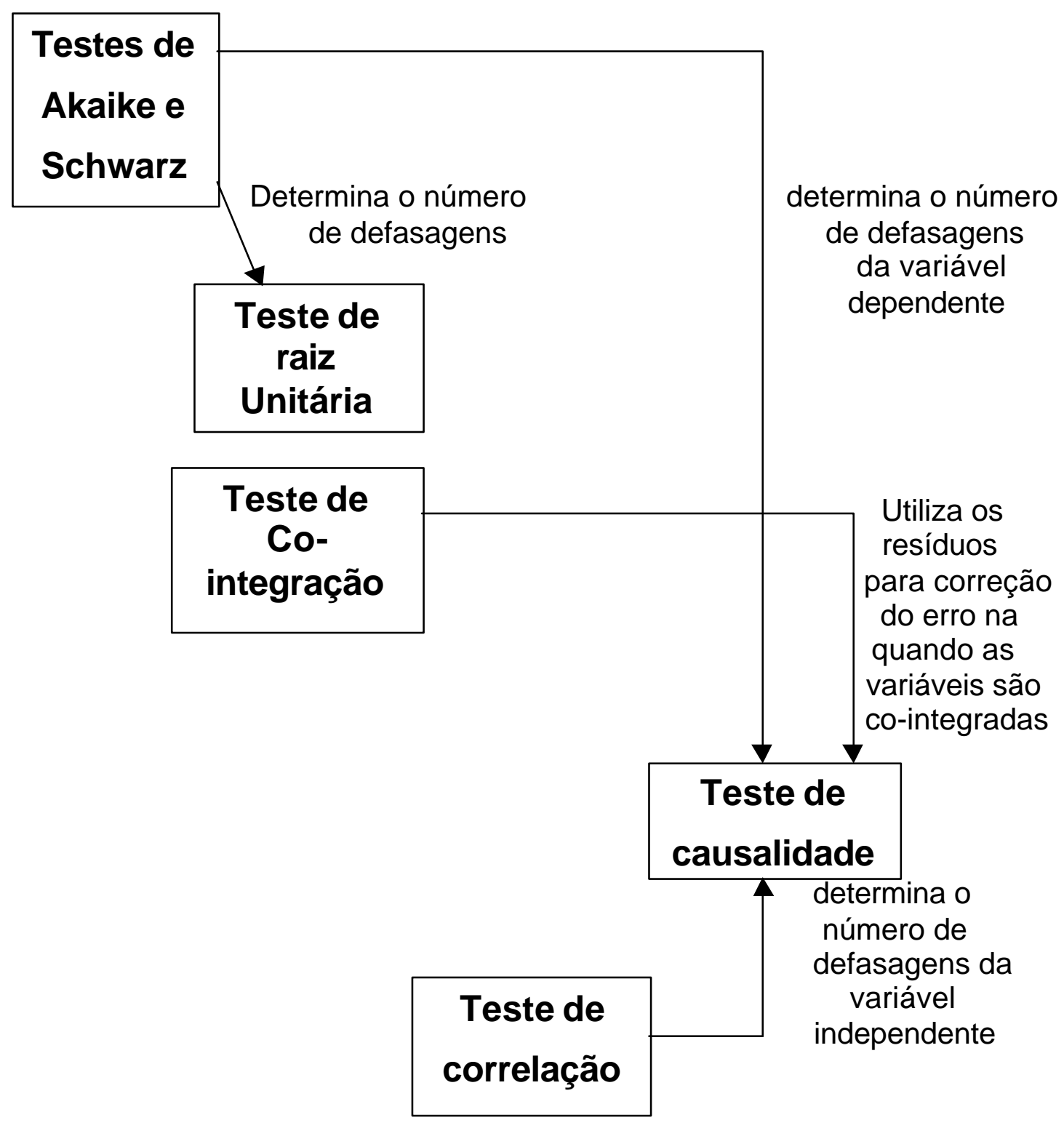

Figura 5 - Esquema geral dos testes econométricos. 
uma variação de $1 \%$ no preço do outro nível de mercado. Permite estudar a margem através da intensidade de transmissão, indicando se algum nível de mercado amplia ou reduz os choques nos preços e quanto tempo é necessário para repassar o choque. Por exemplo, as variações relativas do preço no varejo em relação às variações relativas no preço recebido pelo produtor resulta na seguinte elasticidade, eq. (22).

$$
E v p=\frac{\partial P v}{\partial P p} * \frac{P p}{P v}
$$

onde:

$\mathrm{Pv}=$ preço ao varejo

$\mathrm{Pp}=$ preço recebido pelo produtor

De modo semelhante, é possível obter as elasticidades para as interfaces produtor/atacado e atacado/varejo, dadas, respectivamente, pelas equações. 23 e 24.

$$
\begin{aligned}
& E p a=\frac{\partial P p}{\partial P a} * \frac{P a}{P p} \\
& E a v=\frac{\partial P a}{\partial P v} * \frac{P v}{P a}
\end{aligned}
$$

onde

$\mathrm{Pa}=$ preço no atacado

$\mathrm{Pv}=$ preço ao varejo

$\mathrm{Pp}=$ preço recebido pelo produtor

De acordo com Barros \& Martines Filho (1990), a análise de transmissão de preços agrícolas deve basear-se na seguinte seqüência: a) 
estabelecimento de um modelo teórico que explique a formação de preços no vários níveis de mercado e a forma como suas variações se inter-relacionam; b) teste para verificar se o sentido de causalidade entre os preços de mercado é compatível com o modelo proposto; c) ajustamento de regressões para estimar as elasticidades de transmissão de preços, tendo-se em conta o sentido de causalidade determinado previamente.

Para escolher o modelo a ser utilizado, foi feita uma pesquisa e, devido à importância do tema no âmbito do trabalho, descrevem-se três modelos econômicos, propostos pelos autores Gardner (1975), Heien (1980) e Barros (1990), que são mais utilizados para explicar a formação dos preços em diferentes níveis de mercado.

\subsubsection{Modelo econômico}

Gardner (1975) propôs um modelo analítico conhecido como Modelo de Equilíbrio Estático, ou Modelo Competitivo. Este modelo parte do pressuposto de que os mercados dos produtos e de serviços de comercialização se realizam sob regime de concorrência perfeita e que, após eventos que promovam deslocamentos da oferta ou demanda primária ${ }^{31}$, ocorra equilíbrio instantâneo nos três níveis de mercado.

O modelo de Gardner é estático-comparativo. Considera três níveis de mercado (produtor, atacado e varejo) e considera que, na comercialização agrícola, são utilizados insumos de comercialização para obter o produto final no local de venda ao varejo. O sistema de equações é composto pela função de produção, função de demanda primária, função de demanda por insumos e oferta de insumos. As análises destas equações são realizadas observando as relações entre os preços do produto final e preços da matéria- 
prima. Os preços em diferentes níveis de mercado podem mover-se numa mesma direção ou em direções diferentes.

Este modelo apresenta algumas restrições, entre as quais se destaca a forma funcional. A função deve ter retornos constantes à escala. Esta limitação impede, em determinadas situações, refletir de maneira realista o verdadeiro comportamento dos mercados agrícolas. Sua utilização visa a associar os efeitos de choques da oferta e da demanda sobre os preços e margens de comercialização num determinado sentido de causalidade entre os preços.

O modelo de Heien (1980), ou Modelo de Markup, ou, ainda, Modelo de Desequilíbrio, considera o ajustamento de preços por um processo dinâmico. Teoricamente considera três níveis de mercado, mas, para simplificação do processo dinâmico, trabalha-se somente com os níveis de produtor e varejo. A diferença com o modelo de Gardner está na dinâmica do ajustamento do mercado. Para Heien, quando o tempo é curto, a pressuposição de Gardner de equilíbrio instantâneo entre oferta e demanda não é válida, pois um desequilíbrio passa a ser uma condição freqüente. Desta forma, este modelo teria restrições temporais para analisar comportamentos.

O modelo de Heien não pressupõe a igualdade entre oferta e demanda nos mercados, e sim, que os atacadistas ajustam seus preços de venda por uma política de markup. Por outro lado, os produtores ajustam seus preços proporcionalmente ao excesso de demanda. Desta forma, num primeiro momento, os ajuste se dão através de variações nos estoques. Persistindo o choque que causou a variação nos custos, pode ocorrer um excesso de demanda ou de oferta, provocando, assim, um desequilíbrio, exigindo novos

\footnotetext{
${ }^{31}$ Oferta do produtor e do consumidor
} 
ajustes por parte dos atores da cadeia produtiva. Para Heien, o sentido de causalidade predominante é do produtor para o atacado.

A partir do modelo anterior, Barros (1990) desenvolveu um novo modelo. Outras pressuposições que lhe serviram de bases são: a) que os preços no mercado atacadista se ajustam instantaneamente em virtude das vendas serem centralizadas, de ocorrerem em curtos períodos de tempo, do baixo custo para efetuar as mudanças de preço, possuir maior especialização e por ter maior acesso às informações; b) quando ocorrem transações entre produtor e varejista, são operações descentralizadas e as alterações de preços ocorrem com certa defasagem em relação ao atacado. Este fato ocorre porque os produtores estão pulverizados e detêm pequenas quantidades de produto e, por outro lado, o varejo não é especializado ${ }^{32}$. Desta forma, os preços do varejo e ao produtor alteram-se de forma parcial, sendo que o varejo se ajusta através de uma política de markup, até atingir um preço de equilíbrio, que o autor denomina de "preço meta". Optou-se em utilizar este modelo porque as circunstâncias em que ele se baseia são parecidas com as ocorridas no mercado de feijão. No item seguinte, apresentam-se detalhes sobre o modelo, considerando o mercado de feijão.

\subsubsection{Modelo de Barros (1990)}

O modelo assume que, no curto prazo, as firmas de comercialização no atacado e varejo, operam de acordo uma função do tipo Leontief :

$$
\mathrm{V}=\min \left\{\frac{A}{b_{1}}, \frac{Z}{b_{2}}\right\} \quad(25) \quad \text { e } \quad \mathrm{A}=\min \left\{\frac{P}{c_{1}}, \frac{X}{c_{2}}\right\}
$$

\footnotetext{
${ }^{32}$ Os atacadistas, normalmente, não operam somente com feijão, mas vários outros produtos.
} 
Onde:

$\mathrm{V}=$ quantidade de feijão ao varejo

$A=$ quantidade de feijão ao atacado,

$\mathrm{P}=$ quantidade de feijão ao produtor

$\mathrm{Z}$ e $\mathrm{X}=$ quantidade de insumos de comercialização utilizados ao varejo e atacado

$b_{1}, b_{2}, c_{1}$ e c c, são os coeficientes técnicos da produção.

A demanda ao varejo é dada como uma função linear, eq. (27)

$$
V_{t}{ }^{d}=\theta_{0}+\theta_{1} \text { pre var }{ }_{t} \quad \theta_{1}<0
$$

Onde

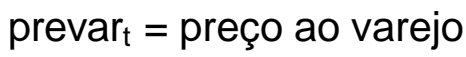

$\theta_{0} e \theta_{1}=$ parâmetros da regressão

O preço de equilíbrio ou "preço meta" ao varejo, é obtido pela prática de markup, e é dado pela equação 28. Porém, é atingido de forma parcial e a equação 29 representa o modelo é dinâmico.

$$
\text { prevar }_{t}^{*}=b_{1} \text { preata }_{t}+b_{2} \text { preins }_{1}
$$

Onde

Prevar $^{*}=$ preço meta ao varejo

preata $=$ preço do feijão no atacado

preins $=$ preço do insumo de comercialização

$b_{1}$ e $b_{2}$, são os coeficientes técnicos da produção. 


$$
\text { pre } \operatorname{var}_{t}-\text { pre } \operatorname{var}_{t-1}=\alpha\left(\text { pre } \operatorname{var}_{t}^{*}-\text { pre }_{\operatorname{var}}{ }_{t-1}\right) \quad 0<\alpha<1
$$

Onde

$\alpha=$ taxa de velocidade de ajustamento desse preço.

A demanda por feijão ao atacado é obtida pela conversão da demanda ao varejo observada no período anterior, eq (30).

$$
A_{t}^{d}=b_{1} V_{t-1}^{d}
$$

Onde

$V_{t-1}^{d}=$ quantidade demandada no varejo no período anterior

$b_{1,=}$ coeficiente técnico da produção

A oferta ao nível de produtor é uma função linear, eq (31).

$$
P_{t}^{s}=\delta_{0}+\delta_{1} \text { prepro }_{t-1} \quad \delta_{1}>0
$$

Onde

prepro $_{\mathrm{t}-1}=$ preço ao produtor defasado um mês

Onde:

$\mathrm{P}_{\mathrm{t}-1}=$ preço recebido defasado 
A oferta ao nível de atacado é obtida pela conversão da oferta ao produtor, eq. (32)

$$
A_{t}^{s}=\frac{P_{t}^{s}}{c_{1}}
$$

onde

$\mathrm{P}^{\mathrm{s}}=$ quantidade ofertado pelo produtor

$c_{1}=$ coeficiente técnico de produção

O modelo considera ainda que o preço ao atacado se ajusta por desequilíbrio entre oferta e demanda, sendo representado por excesso de demanda pelo produto, ou seja:

$$
\text { preata }_{t}-\text { preata }_{t-1}=\boldsymbol{\delta}\left(A_{t}^{d}-A_{t}^{s}\right) \quad \delta>0
$$

Onde

preata $=$ preço do feijão no atacado

$A^{d}=$ quantidade de feijão demandada no atacado,

$A^{S}=$ quantidade de feijão ofertada pelo produtor,

$\delta=$ taxa de velocidade de ajustamento do preço, por excesso de demanda, no atacado.

O preço de equilíbrio ao produtor é estabelecido por eq. (34). 


$$
\text { prepro }_{t}^{*}=\frac{\text { preata }_{t}-c_{2} \operatorname{preins}(a)_{t}}{c_{1}}
$$

Onde

preata $=$ preço do feijão ao atacado

preins $(\mathrm{a})=$ preço do insumo de comercialização no atacado

$\mathrm{c}_{1}$ e c $\mathrm{C}_{2}$, são os coeficientes técnicos da produção.

O ajustamento do preço ao produtor se dá por ajustes parciais

$$
\text { prepro }_{t}-\text { prepro }_{t-1}=\beta\left(\text { prepro }_{t}^{*}-\text { prepro }_{t-1}\right) \quad 0<\beta>1
$$

onde

prepro $=$ preço ao produtor

prepro $^{*}=$ preço de equilíbrio ao produtor

Promovendo substituições e rearranjando os termos, obtém-se as seguintes equações de transmissão de preços

$$
\text { pre } \operatorname{var}_{t}=(1-\alpha) \text { pre } \operatorname{var}_{t-1}+\alpha b_{1} \text { preata }_{t}+\alpha b_{2} \text { preins }(v)_{1}
$$

onde

prevar $=$ preço ao varejo

preata $=$ preço ao atacado

$\operatorname{preins}(\mathrm{v})=$ preço insumo de comercialização ao varejo 


$$
\text { prepro }_{t}=(1-\beta) \text { prepro }_{t-1}+\frac{\beta}{c_{1}} \text { preata }_{t}-\frac{\beta . c_{2}}{c_{1}} \text { preins }(a)_{t}
$$

onde

prepro $=$ preço recebido pelo produtor

preata $=$ preço ao atacado

preins $(\mathrm{a})=$ preço insumo de comercialização ao atacado

Após o cálculo das elasticidades utilizando as equações 36 e 37, foi calculado também o período de tempo que demora para o ajustamento dos preços ao nível de varejo e produtor. $\mathrm{Na}$ estimativa foi considerado um ajustamento de $95 \%$ dos preços. As equações utilizadas foram as seguintes.

$$
P m(v)=\frac{\ln 0,05}{\ln (1-\alpha)} \quad \text { (38) } \quad P m(p)=\frac{\ln 0,05}{\ln (1-\beta)}
$$

onde

$\mathrm{Pm}(\mathrm{v})=$ período de tempo, em meses, para que ocorra 95\% do ajustamento dos preços no varejo, quando ocorre uma alteração no preço do atacado

$\operatorname{Pm}(p)=$ período de tempo, em meses, para que ocorra 95\% do ajustamento dos preços em nível de produtor, quando ocorre uma alteração no preço do atacado

Por fim, foram calculadas as elasticidades total e parcial da transmissão entre atacado e varejo e atacado e produtor. No primeiro caso, utilizaram-se as equações 40 e 41 . No segundo, as equações 42 e 43, respectivamente. 


$$
\begin{array}{lll}
\operatorname{Eav}(t)=b_{1} \frac{\operatorname{preata}(m)}{\operatorname{prevar}(m)} & (40) & \operatorname{Eav}(p)=\alpha b_{1} \frac{\operatorname{preata}(m)}{\operatorname{pre} \operatorname{var}(m)} \\
\operatorname{Eap}(t)=\frac{\beta}{c_{1}} \frac{\operatorname{preata}(m)}{\operatorname{prepro}(m)} & (42) & \operatorname{Eap}(p)=\frac{1}{c_{1}} \frac{\operatorname{preata}(m)}{\operatorname{prepro}(m)}
\end{array}
$$

onde

$\operatorname{Eav}(\mathrm{t})=$ elasticidade total da transmissão de preços entre os níveis atacado e varejo

$\operatorname{Eav}(p)=$ elasticidade parcial da transmissão de preços entre os níveis atacado e varejo

$\operatorname{Eap}(\mathrm{t})=$ elasticidade total da transmissão de preços entre os níveis atacado e produtor

$\operatorname{Eap}(p)=$ elasticidade parcial da transmissão de preços entre os níveis atacado e produtor

Preata $(m)=$ preço médio ao atacado no período em questão

$\operatorname{Prevar}(m)=$ preço médio ao varejo no período em questão

Prepro $(m)=$ preço médio recebido pelo produtor no período em questão

\subsection{Aspectos gerais do consumo}

O consumo per capita anual neste trabalho foi calculado utilizando dados de produção do Levantamento Sistemático da Produção Agrícola (IBGE, 1990...). Primeiramente, calculou-se uma estimativa mensal da quantidade colhida nos Estados. Depois, considerando o ano civil, estas quantidades foram 
somadas para obter a quantidade total ofertada. Ao valor encontrado foi somada a quantidade importada para encontrar o consumo total.

Para o cálculo do consumo aparente, como não foi possível estimar os estoques de passagem e nem a quantidade destinada para sementes, estas informações foram estimadas. No primeiro caso foi utilizado um valor médio de 300 mil toneladas. No segundo, considerou-se que cerca de $8 \%$ da produção total é utilizada como semente. Além disso, considerou-se também que $3 \%$ da quantidade total disponível para consumo são perdidos durante o transporte e armazenamento.

\subsection{Projeção do consumo}

Para estimar a projeção de consumo optou-se utilizar uma metodologia fundamentada no princípio da elasticidade renda, em detrimento as que se baseiam em produtos substitutos, em virtude da diversidade encontrada para os produtos substitutos para o feijão. A Comissão de Financiamento da Produção (1981) apresentou como substituto o trigo, Roessing et al (1998) apresentaram o frango, enquanto Spers \& Nassar (1998) e Ferreira \& Yokoyama (1999) ${ }^{33}$ não encontraram um substituto direto. Diante do exposto, para fazer a projeção de consumo, foi utilizada a equação apresentada por Barros (1987).

$$
Q_{t}=\left(Q_{o} *\left(1+e_{y} * r_{y}\right)^{t} *(1+p)^{t}\right)
$$

Onde,

$Q_{t}=$ Quantidade total demandada no ano considerado

$Q_{0}=$ Quantidade consumida no ano inicial

${ }^{33}$ Relaciona-se esta dificuldade em apresentar substitutos do feijão com a fato de ele ter profundas raízes no hábito alimentar dos brasileiros, levando as pessoas a não perceberem que em determinadas situações e com o tempo está havendo uma gradual substituição do feijão por outros alimentos. 
$e_{y}=$ Elasticidade renda da demanda do produto em questão

$r_{y}=$ Taxa de crescimento da renda per capita

$p=$ Taxa de crescimento da população

A equação de Barros (1987) não considera as possíveis causas da diminuição do consumo per capita de feijão, fato que está ocorrendo de forma permanente e constante nas últimas décadas, ou seja, baseado-se nos resultados e na discussão da tabela 9, foi estimada a taxa de crescimento do consumo per capita utilizando a média das décadas de 70 a 80 . O valor encontrado foi de 0,70 . Portanto, o consumo per capita neste período decresceu cerca de $1 \%$ ao ano. Desta forma, na tentativa de se obter um melhor ajuste, foi introduzido na equação 44 um fator de correção - FC, e transformou-se a quantidade calculada em demanda per capita, obtendo-se a equação 45. O valor de FC para o ano 1 da estimativa foi de 0,99; para o ano 2, de 0,98; para o ano 3, de 0,97; e assim sucessivamente.

$$
Q_{m t}=\left(\frac{\left(Q_{o} *\left(1+e_{y} * r_{y}\right)^{t} *(1+p)^{t}\right)}{p o p}\right) * F C
$$

onde

$Q_{m t}=$ Demanda per capita no ano considerado

pop $=$ População estimada 
A quantidade inicial $Q_{0}$ utilizada foi obtida através da média de consumo total na década de 90. Devido às incertezas econômicas que o País atravessa, para o cálculo da evolução da renda per capita anual, foram utilizadas taxas alternativas de crescimento de $0 \%, 2 \%, 3 \%$ e 4\%. A situação de crescimento zero também pode ser interpretada no caso de haver crescimento, mas sem haver distribuição de renda. A estimativa da população foi calculada a partir de dados do censo (IBGE, 1996), com uma taxa de crescimento anual de $1,12 \%$.

Para estimar a elasticidade-renda por feijão foram utilizadas as informações da Pesquisa de Orçamento Familiar - POF dos anos 1987 e 1996 (IBGE, 1991 e IBGE,1998), e a função logarítmica:

$$
\log Q_{i j}=a+b * \log Y_{i j}
$$

onde, $Q_{i j}=$ Quantidade per capita de feijão tipo i pelo estrato j de renda $Y_{i j}=$ Renda média do estrato $\mathrm{j}$ 


\section{ANÁLISE DOS RESULTADOS}

Neste tópico serão apresentados e comentados os resultados deste estudo, que serão comparados com resultados de outros estudos.

\subsection{Abrangência geográfica e temporal da produção, importação e principais fluxos de comercialização de feijão no Brasil}

Foram identificados como principais Estados ${ }^{34}$ produtores de feijão na década de 1990: Rio Grande do Sul, Santa Catarina, Paraná, São Paulo, Minas Gerais Goiás e Bahia. A Tabela 12 mostra que estes Estados produziram, em média, $71 \%$ da produção total. No período de janeiro/90 a dezembro/99, o ano de menor participação destes Estados foi o de 1996, com $63 \%$, e o de maior, 1998, com $90 \%$. A média do percentual de participação destes Estados está aumentando, pois Junqueira et al. (1971) verificaram que, nos anos 60, estes mesmos Estados respondiam por 62\%.

Observa-se na Tabela 13, que antes e após o ano de 1994, a produção dos Estados da Bahia, São Paulo, Santa Catarina e Rio Grande do Sul reduziram suas produções, respectivamente em 10,505 mil toneladas, 56,785 mil toneladas, 53,368 mil toneladas e 21,008 mil toneladas, que correspondem a diminuição de 3\%, 19\%, 17\% e 13\%, enquanto nos Estados de Minas Gerais, Paraná e Goiás aumentou, respectivamente em 23,585 mil

\footnotetext{
${ }^{34}$ Neste estudo são chamados de Estados produtores e os demais de Estados são chamados de consumidores
} 
toneladas, 76,797 mil toneladas, 15,240 mil toneladas, que correspondem a um crescimento de $7 \%, 18 \%$ e $12 \%$. No cômputo geral, a quantidade média ofertada pelos Estados produtores reduziu em 1,3\%, ou seja 25.774 mil toneladas. Por outro lado ocorreu um crescimento de $10 \%$ da produção média dos outros Estados, aproximadamente 78.666 mil toneladas. Constatou-se que esse desempenho deveu-se, praticamente, ao crescimento da produção da Região Nordeste, que, no primeiro período, produzia cerca de 479,512 mil toneladas e, após 1995, passou sua média anual para 584,701 mil toneladas. O resultado final foi que a produção total cresceu cerca de $2 \%$ após o Plano Real.

Como complemento de análise do comportamento dos Estados produtores, foram calculadas algumas relações das produções médias anuais entre eles considerando o período total 1990 a 1999, e os sub-períodos de 1990 a 1994 e de 1995 a 1999. Quando os valores da Tabela 14 são menores do que a unidade, indicam que a quantidade colhida no Estado discriminado na coluna é menor em relação à do Estado discriminado na linha. Quando é maior do que um, o raciocínio é inverso. A partir de 1995, a produção do Estado de São Paulo diminuiu em relação a todos os outros Estados. Em compensação, a do Paraná aumentou em relação aos demais. Nas outras relações, observa-se um equilíbrio, ou seja, enquanto algumas subiram outras diminuíram. Desta forma, a produção total, conforme já comentado, manteve-se estável. 
Tabela 13. Produção total anual de feijão no Brasil, nos principais Estados produtores e nas demais regiões, no período de 1990-99 (1000 toneladas).

\begin{tabular}{|c|c|c|c|c|c|c|c|c|c|c|c|c|}
\hline \multirow{2}{*}{\multicolumn{2}{|c|}{ ANOS }} & \multicolumn{7}{|c|}{ Principais estados produtores } & \multicolumn{2}{|c|}{ Subtotal } & \multirow{2}{*}{$\begin{array}{l}\text { Outros } \\
\text { estados }\end{array}$} & \multirow{2}{*}{ Total } \\
\hline & & $\mathrm{BA}$ & MG & SP & PR & SC & $\mathrm{RS}$ & GO & Produção & $\%$ & & \\
\hline & 1990 & 227,194 & 293,478 & 259,524 & 352,047 & 260,915 & 125,497 & 118,960 & 1627,615 & 72,0 & 636,000 & 2273,615 \\
\hline & 1991 & 359,257 & 333,256 & 203,745 & 470,753 & 320,002 & 76,459 & 121,532 & 1855,003 & 65,1 & 1009,837 & 2994,840 \\
\hline & 1992 & 449,114 & 287,457 & 404,405 & 399,552 & 288,089 & 285,083 & 113,296 & 2226,996 & 77,4 & 649,372 & 2876,368 \\
\hline & 1993 & 313,634 & 362,074 & 291,446 & 574,405 & 276,059 & 109,117 & 125,218 & 2051,953 & 83,3 & 411,221 & 2463,174 \\
\hline & 1994 & 303,309 & 367,380 & 283,989 & 333,660 & 358,478 & 190,497 & 144,635 & 1881,949 & 66,9 & 1062,511 & 3044,406 \\
\hline & 1995 & 251,616 & 344,004 & 250,174 & 509,199 & 316,945 & 159,426 & 92,514 & 1923,876 & 66,0 & 1034,282 & 2958,159 \\
\hline & 1996 & 317,424 & 336,650 & 190,016 & 515,114 & 274,830 & 107,973 & 114,237 & 1856,243 & 63,6 & 1058,358 & 2914,602 \\
\hline & 1997 & 469,696 & 379,544 & 199,855 & 429,295 & 245,939 & 123,123 & 168,234 & 2015,685 & 69,5 & 883,928 & 2899,613 \\
\hline & 1998 & 229,992 & 320,517 & 238,040 & 514,560 & 188,154 & 137,902 & 154,113 & 1783,277 & 89,9 & 419,946 & 2203,223 \\
\hline & 1999 & 331,257 & 382,188 & 281,110 & 546,235 & 210,837 & 153,191 & 170,742 & 2075,561 & 73,0 & 765,757 & 2841,318 \\
\hline $\mathrm{M}^{*}$ & $90 / 99$ & 325,249 & 340,655 & 260,230 & 464,482 & 274,025 & 146,827 & 132,348 & 1943,816 & 71,0 & 793,121 & 2736,937 \\
\hline$M^{*}$ & $90 / 94$ & 330,502 & 328,729 & 288,622 & 426,083 & 300,709 & 157,331 & 124,728 & 1956,703 & 72,1 & 753,788 & 2710,492 \\
\hline$\%$ & & 12,19 & 12,13 & 10,65 & 15,72 & 11,09 & 5,80 & 4,60 & 72,19 & & 27,81 & 100 \\
\hline$N$ & & 319,997 & 352,581 & 231,839 & 502,880 & 247,341 & 136,323 & 139,968 & 1930,929 & 69,8 & 832,454 & 2763,383 \\
\hline$\%$ & & 11,58 & 12,76 & 8,39 & 18,20 & 8,95 & 4,93 & 5,06 & 69,88 & & 30,12 & 100 \\
\hline
\end{tabular}

Fonte: Levantamento Sistemático da Produção (IBGE, 1990...), adaptado pelo autor.

$\mathrm{M}^{*}=$ média 
Tabela 14. Relação entre as produções dos estados.

\begin{tabular}{|c|c|c|c|c|c|c|c|}
\hline Estado & Período & RS & $\mathrm{SC}$ & PR & MG & $\mathrm{GO}$ & $\mathrm{BA}$ \\
\hline & Jan90-dez/99 & 1,77 & 0,95 & 0,56 & 0,76 & 1,97 & 0,80 \\
\hline \multirow[t]{3}{*}{ SP } & Jan90-dez/94 & 1,83 & 0,96 & 0,68 & 0,88 & 2,31 & 0,87 \\
\hline & Jan95-dez/99 & 1,70 & 0,94 & 0,46 & 0,66 & 1,66 & 0,72 \\
\hline & Jan90-dez/99 & & 0,54 & 0,32 & 0,43 & 1,11 & 0,45 \\
\hline \multirow[t]{3}{*}{ RS } & Jan90-dez/94 & & 0,52 & 0,37 & 0,48 & 1,26 & 0,48 \\
\hline & Jan95-dez/99 & & 0,55 & 0,27 & 0,39 & 0,97 & 0,43 \\
\hline & Jan90-dez/99 & & & 0,59 & 0,80 & 2,07 & 0,84 \\
\hline \multirow[t]{3}{*}{ SC } & Jan90-dez/94 & & & 0,71 & 0,91 & 2,41 & 0,91 \\
\hline & Jan95-dez/99 & & & 0,49 & 0,70 & 1,77 & 0,77 \\
\hline & Jan90-dez/99 & & & & 1,36 & 3,51 & 1,43 \\
\hline \multirow[t]{3}{*}{ PR } & Jan90-dez/94 & & & & 1,30 & 3,42 & 1,29 \\
\hline & Jan95-dez/99 & & & & 1,43 & 3,59 & 1,57 \\
\hline & Jan90-dez/99 & & & & & 2,57 & 1,05 \\
\hline \multirow[t]{3}{*}{ MG } & Jan90-dez/94 & & & & & 2,64 & 0,99 \\
\hline & Jan95-dez/99 & & & & & 2,52 & 1,10 \\
\hline & Jan90-dez/99 & & & & & & 0,41 \\
\hline \multirow[t]{2}{*}{ GO } & Jan90-dez/94 & & & & & & 0,38 \\
\hline & Jan95-dez/99 & & & & & & 0,44 \\
\hline
\end{tabular}

Portanto, entre os anos 1990 a 1994 e 1995 a 1999, não foram encontradas evidências contundentes de que algum Estado tenha dedicado maior empenho para desenvolver com mais vigor a produção desta cultura. Destarte, as mudanças políticas associadas com o Plano Real não alteraram o perfil da produção de feijão nos principais Estados produtores. O que se observou foi uma alternância de produção entre eles. Por outro lado, houve um incentivo de produção na região Nordeste - ressalte-se que nesta estatística não está incluído o Estado da Bahia, que foi analisado junto com os principais produtores. 
Aliás, este fenômeno de alternância de produção também foi observado ao se estudarem as produções municipais, no período de 1990 a 1996. Neste período, no Brasil existiam aproximadamente 5.550 municípios que produziam feijão, agrupados em microrregiões ${ }^{35}$. Verificou-se que as 50 principais microrregiões, em cada ano, respondiam, em média, por $60 \%$ da produção total. Portanto, cerca de $40 \%$ da produção estava diluída em 500 microrregiões. Em compensação, a média percentual da microrregião com maior produção era de $5 \%$ em relação à produção total. A partir da quinta região, a concentração entra na casa de $1 \%$ e, a partir da vigésima, está abaixo de $1 \%$.

Nas Tabelas A14 a A19 (anexo) observa-se, também, que algumas microrregiões produtoras aparecem com mais constância entre as dez primeiras, mas, mesmo assim, há uma constante troca de posições entre elas. No entanto, apesar destas variações entre Estados/microrregiões, a produção total anual manteve-se com uma certa estabilidade.

Diante do exposto, derivam-se as seguintes conclusões: a) cerca de dois terços da produção de feijão está concentrada em poucas microrregiões. Portanto, é indiscutível a importância dos Estados produtores; b) nos Estados produtores existem microrregiões com maior participação e influência no abastecimento nacional, mas a quantidade ofertada por elas pode mudar de ano para ano; c) a Região Nordeste aumentou a produção de feijão. A partir deste contexto tem-se alguns elementos que causam a dificuldade de 0 produtor obter informações do mercado e o fato de os intermediários só conseguirem definir suas estratégias de compra e venda depois que a safra está totalmente definida.

\footnotetext{
${ }^{35}$ De acordo com a divisão utilizada pelo IBGE
} 
O resultado do estudo sobre o índice médio mensal de distribuição de colheita de feijão no Brasil é mostrado na Figura 6, onde se observa que os meses de dezembro/janeiro a junho são picos das safras das águas e seca, respectivamente. No período de fevereiro a maio, ocorrem colheitas com índices próximos à média de $8 \%$. Resultados parecidos são observados em julho e agosto. No período de setembro a novembro, os índices são abaixo da média. Portanto, de dezembro a agosto colhe-se mais de $91 \%$ do total produzido no ano e no período de entressafra - setembro a novembro colhe-se cerca de $9 \%$, quantidade que garante produto novo para atender mercados mais exigentes.

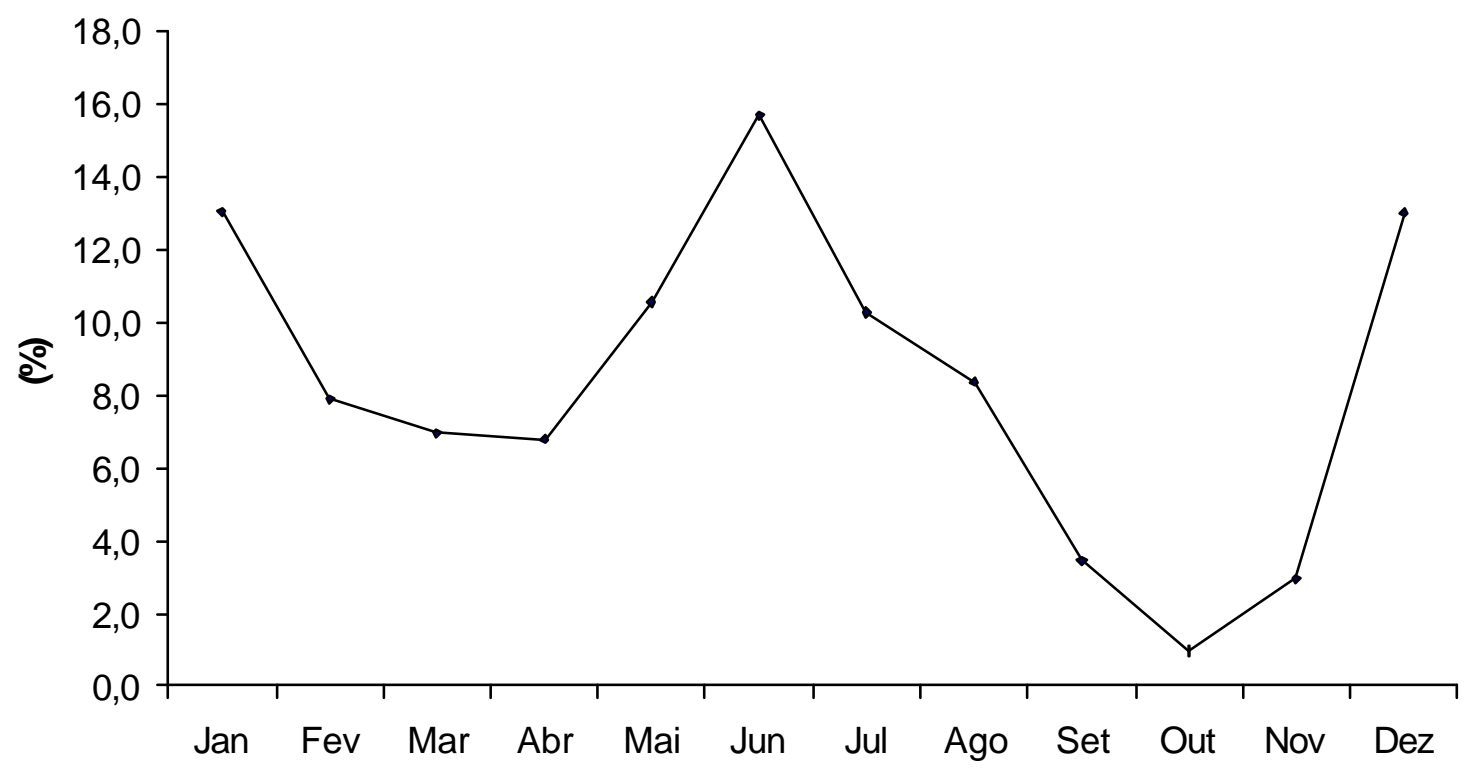

Figura 6 - Média percentual mensal em relação ao total colhido. Período de 1900-99.

Fonte: Levantamento Sistemático da Produção (IBGE, 1990...), Brasil (1991...), Anuário Estatístico do Brasil (IBGE, 1996), adaptados pelo autor. 
O resultado do estudo da distribuição do índice médio percentual mensal de colheita de feijão nos Estados produtores e demais regiões é apresentado na Tabela 15. Observa-se que a Região Norte, que colhe somente a segunda safra, tem maior participação nos meses de junho a julho e de setembro a outubro. Nesta Região, somente o Estado de Rondônia interage com outras regiões do País, principalmente com o mercado paulista. Nos demais Estados, Pará, Roraima, Acre, Amazonas ${ }^{36}$, a produção se destina ao mercado regional.

A colheita da Região Nordeste ocorre com maior intensidade no período de março a setembro. Normalmente, o produto desta Região não abastece os Estados da Região Sul, mas o resultado da safra pode influenciar o comportamento do mercado no âmbito nacional, pois determina a pressão de demanda que os intermediários desta Região vão exercer por feijão nos Estados da Região Centro-Sul.

Nos outros Estados da Região Centro - Sul, concentram-se as colheitas entre março a setembro. Apesar de ser relativamente pequena, sua participação no abastecimento das regiões consumidoras é importante, haja vista que existe um equilíbrio na dinâmica de oferta e demanda de feijão no Brasil; assim, qualquer falha pode causar perturbações.

$\mathrm{Na}$ Bahia, dois períodos de colheitas são significativos no contexto nacional. Nos dois primeiros meses do ano, quando a região de Irecê é a principal região produtora, pois responde por até $50 \%$ da produção total deste Estado. O outro período é de junho a setembro, sendo que de junho a julho é colhida a segunda safra, cuja produção está diluída em todo Estado e de julho a setembro, a colheita refere-se, principalmente, à safra irrigada, sendo Barreiras a principal região produtora.

\footnotetext{
${ }^{36}$ praticamente só planta caupi
} 
Em Minas Gerais, a colheita da safra das águas inicia-se em janeiro, mas o mês de maior concentração é fevereiro. Em março, o nível de colheita mantém-se em posição de destaque. Outro período em que as colheitas deste Estado são importantes é de maio a junho; refere-se à safra da seca. No mês de maio, o índice de colheita tem magnitude semelhante a outros Estados, mas no mês de junho é o Estado da Região Centro Sul que mais colhe. No período de julho a setembro, é colhida a safra irrigada.

Em São Paulo, a colheita da primeira safra inicia-se em novembro ${ }^{37}$ e termina em janeiro. Em fevereiro são colhidas poucas áreas remanescentes. Em abril, o Estado volta a colher - safra da seca- pequena parte da produção é colhida em maio e julho. Em julho inicia a colheita da safra irrigada que tem seu auge em agosto. Setembro colhe-se o remanescente da terceira safra.

O Paraná consegue colher parte da safra das águas a partir de outubro, sendo que a maior concentração ocorre em dezembro e janeiro. Nos outros meses do ano, o índice de colheita em relação ao restante do País é menos significativo, mas há a vantagem de a colheita ser continua. Assim, este Estado sempre oferta feijão novo e é o que mais contribui para o abastecimento geral. É Importante salientar que, na colheita da primeira safra, cerca de $50 \%$ do feijão produzido é do tipo preto.

Em Santa Catarina, as colheitas nos meses de dezembro e janeiro são significativas no contexto nacional. A quantidade colhida no mês de dezembro possui uma estabilidade que não é observada no mês de janeiro. Em março, praticamente não ocorre colheita. Em abril e maio, volta-se a colher e a partir de junho não é possível colher por causa do inverno. No Rio Grande do Sul, o esquema é o mesmo de Santa Catarina.

\footnotetext{
${ }^{37}$ Nos últimos anos da década de 90, São Paulo apresentou tendência de antecipar a colheita da safra das águas para o mês de novembro. Certamente este esforço visa a entrar com o produto no mercado em período de entressafra.
} 
Em Goiás, as safras das águas e da seca não são de grandes proporções, mas têm seu papel no equilíbrio geral. O destaque fica para os meses de maio e agosto, quando são colhidos quinhões significativos. $O$ primeiro período tem este desempenho em função de algumas regiões no Estado que intensificaram o plantio de feijão como alternativa ao milho, principalmente no Sudoeste Goiano. No segundo período, há a safra irrigada, com maior concentração de colheita nos meses de agosto e setembro.

Tabela 15. Percentual médio anual e mensal do índice de colhida nas regiões Norte, Nordeste, outros Estados da Região Centro Sul e nos principais Estados produtores de feijão, no período de 1990 a 1999.

\begin{tabular}{lrrrrrrrrrr}
\hline & \multicolumn{10}{c}{ Percentual médio - Região/Estado } \\
\cline { 2 - 11 } & \multicolumn{10}{c}{ Eensal } \\
\cline { 2 - 11 } & Norte* $^{*}$ NE $^{* *}$ & CS & \multicolumn{1}{c}{ BA } & MG & SP & PR & \multicolumn{1}{c}{ SC } & \multicolumn{1}{c}{ RS } & GO \\
\hline Jan & 0,0 & 0,1 & 3,9 & 8,6 & 5,6 & 8,1 & 34,5 & 23,3 & 16,8 & 1,6 \\
Fev & 0,0 & 0,2 & 4,2 & 35,5 & 26,6 & 1,6 & 10,0 & 16,1 & 6,0 & 4,7 \\
Mar & 1,5 & 34,4 & 12,3 & 0,0 & 10,6 & 15,8 & 9,0 & 8,5 & 4,8 & 11,0 \\
Abr & 1,3 & 33,8 & 3,5 & 0,0 & 5,6 & 12,3 & 13,8 & 22,2 & 5,0 & 5,2 \\
Mai & 1,5 & 34,4 & 12,3 & 0,0 & 10,6 & 15,8 & 9,0 & 8,5 & 4,8 & 11,0 \\
Jun & 16,2 & 35,0 & 11,2 & 9,7 & 18,9 & 5,7 & 1,5 & 2,2 & 0,6 & 1,7 \\
Jul & 11,8 & 25,8 & 7,7 & 33,4 & 5,7 & 9,9 & 0,8 & 0,0 & 0,0 & 7,0 \\
Ago & 4,3 & 40,4 & 11,8 & 10,9 & 11,8 & 13,6 & 2,3 & 0,0 & 0,0 & 14,0 \\
Set & 15,3 & 5,9 & 9,3 & 8,6 & 33,2 & 15,1 & 3,1 & 0,0 & 0,0 & 13,3 \\
Out & 12,1 & 0,0 & 0,0 & 0,0 & 57,3 & 0,0 & 34,1 & 0,0 & 0,0 & 0,0 \\
Nov & 0,0 & 0,0 & 3,7 & 0,0 & 16,8 & 37,3 & 59,6 & 2,4 & 6,4 & 0,0 \\
Dez & 0,0 & 0,0 & 2,7 & 0,0 & 3,1 & 12,4 & 48,6 & 23,7 & 12,4 & 0,0 \\
\hline $\mathrm{M}^{* * * *}$ & 4,8 & 18,6 & 6,5 & 11,3 & 12,5 & 9,8 & 16,5 & 10,1 & 5,3 & 4,6 \\
\hline
\end{tabular}

Fonte: Levantamento Sistemático da Produção (IBGE, 1990...), adaptado pelo autor.

* Região Norte

** Região Nordeste (sem a Bahia)

*** Demais Estados formadores da Região Centro Sul (RJ, ES, MS e MT)

**** Média percentual da participação do região/Estado na produção total anual 
Com relação à importação, na Tabela 16 observa-se que, na década de 60, a quantidade importada correspondeu, em média, a 0,14\%, do total consumido; na década de 70 , a $0,66 \%$; e, na de 80 , a 1,11\%. Na década de 90 , aumentou para 3,8\%. Mais especificamente sobre a década de 90, denota-se que a média de importação nos anos de 1990 a 1993 foi de 2,3\%, e no período de 1994 a 1999 passou para 4,7\% em relação ao consumo total. Portanto, depois do Plano Real aconteceu um incremento de 2,4\%. Em termos absolutos isto significou que no primeiro período a média importada foi de 67,875 mil toneladas/ano e no segundo período a média foi de 157,183 mil toneladas/ano.

Tabela16. Quantidades (1000 Toneladas) de feijão importado e percentual em relação à produção interna, no período de 1960 a 1999.

\begin{tabular}{lcc|cc|cc|cc}
\hline \multirow{2}{*}{ Anos } & \multicolumn{7}{c}{ Décadas } \\
\cline { 2 - 10 } & \multicolumn{2}{c}{60} & \multicolumn{2}{c}{70} & \multicolumn{2}{c}{80} & \multicolumn{2}{c}{90} \\
\cline { 2 - 10 } & Quant & $\%$ & Quant & $\%$ & Quant & $\%$ & Quant & $\%$ \\
\hline 0 & 0,000 & 0,00 & 1,700 & 0,07 & 34,800 & 1,72 & 70,300 & 2,83 \\
1 & 0,200 & 0,01 & 2,100 & 0,07 & 5,600 & 0,20 & 88,600 & 2,94 \\
2 & 0,158 & 0,07 & 1,200 & 0.04 & 3,500 & 0,10 & 57,700 & 1,73 \\
3 & 0,200 & 0,01 & 13,900 & 0,52 & 3,700 & 2,18 & 54,900 & 1,85 \\
4 & 0,000 & 0,00 & 1,400 & 0,05 & 60,500 & 2,13 & 156,400 & 4,35 \\
5 & 0,800 & 0,03 & 3,700 & 0,14 & 15,300 & 0,57 & 189,500 & 5,06 \\
6 & 15,454 & 0,62 & 52,700 & 2,31 & 95,000 & 3,48 & 160,100 & 4,45 \\
7 & 11,770 & 0,41 & 81,800 & 3,07 & 35,000 & 1,42 & 157,400 & 4,60 \\
8 & 6,685 & 0,24 & 7,600 & 0,28 & 10,000 & 0,34 & 189,700 & 7,26 \\
9 & 1,352 & 0,05 & 0,700 & 0,03 & 25,000 & 0,94 & 90,000 & 2,93 \\
\hline Média & 3,798 & 0,14 & 16,680 & 0,66 & 29,340 & 1,11 & 121,460 & 3,80 \\
\hline
\end{tabular}

Fonte: Levantamento Sistemático da Produção (IBGE, 1990...), adaptado pelo autor. 
De forma geral, nos meses de janeiro e fevereiro o mercado paulista é abastecido com feijão remanescente da colheita de dezembro do próprio Estado, alguma produção colhida no mês e complementada com produto dos Estados do sul e da produção de Minas Gerais, Goiás, Bahia e Mato Grosso do Sul. Em março, os Estados de São Paulo, Santa Catarina e Rio Grande do Sul não colhem mais. Em abril, inicia a colheita da segunda safra, que vai até junho. Neste período, volta a entrar produto do próprio Estado, de Goiás, Rio Grande do Sul, Paraná, Santa Catarina, Minas Gerais, Mato Grosso do Sul, Mato Grosso. Rondônia desempenha um papel importante no abastecimento, neste período que ocorrem colheitas em todo País. No inicio de junho, o Rio Grande do Sul e Santa Catarina encerram suas colheitas e iniciamse as da Bahia (Barreiras) ${ }^{38}$. Entre julho e agosto, às vezes, o mercado recebe produto importado. Em setembro, encerram-se as colheitas do Paraná e das lavouras irrigadas de São Paulo, Goiás. Bahia, Mato Grosso do Sul e Mato Grosso e de Minas Gerais. Novembro é considerado período de entressafra, a oferta é baixa e se restringe às safras precoces de São Paulo, Paraná e Rio Grande do Sul. Em dezembro, intensificam as colheitas nestes Estados.

A Figura 7 mostra os principais fluxos do mercado paulista. No entanto, apesar de a análise ter sido feita referindo-se a um mercado especifico, ela é um referencial das transações que ocorrem no plano nacional. Neste caso, falta incluir a Região Nordeste, onde a principal colheita ocorre nos meses de julho e agosto.

\footnotetext{
${ }^{38}$ No período de agosto e setembro, a Bahia é a maior responsável pelo abastecimento de São Paulo (Informações Econômicas, out. 1992). A metade da safra de Irecê e Barreiras é destinada ao mercado atacadista de São Paulo e a outra ao mercado nordestino. a Bahia (Informações Econômicas, fev. 1990).
} 


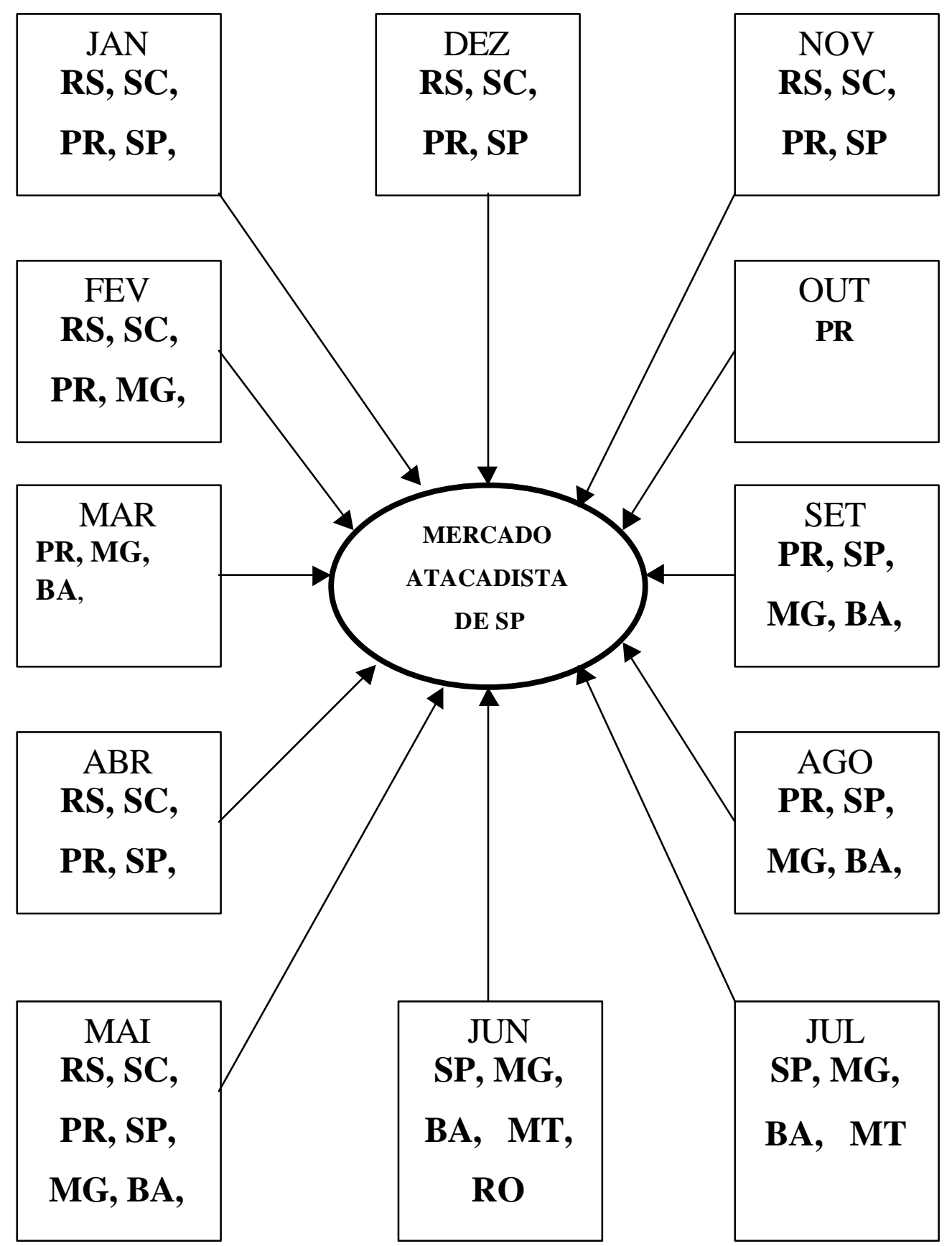

Figura 7 - Fluxos mensais de colheitas nos Estados que influenciam 0 mercado atacadista de são Paulo.

Fonte: elaborada pelo autor. 


\title{
4.2 Preços mensais recebidos pelos produtores nos principais Estados produtores de feijão no Brasil e preços nos mercados atacadista e varejista da cidade de São Paulo
}

\begin{abstract}
Algumas restrições devem ser feitas antes de se abordar 0 assunto preços. Devido às diferentes metodologias que as instituições utilizam nos levantamentos, os valores entre as séries apresentam consideráveis divergências. Além disso, trata-se de preços médios de mercado. Assim, os resultados não devem ser tomados como valores exatos, mas como uma tendência do agregado de comerciantes operando em determinado nível de mercado.
\end{abstract}

A Tabela 17 apresenta os valores dos preços médios nos Estados durante a década de 90 . Quando se divide o período em antes e depois do Plano Real - de 1990 a 1994 e de 1995 a 1999, tem-se que o preço no segundo período é menor cerca de 33\%. São Paulo foi o Estado que apresentou a maior queda e o Rio Grande do Sul, a menor. Os preços ao atacado e varejo de São Paulo também reduziram, 33\% e 25\%, respectivamente. As mudanças entre os demais estados são variadas e não se percebe nenhum resultado com importância especial. Observa-se também, que a participação do atacado em relação ao varejo cresceu de $25,5 \%$ para $37,8 \%$ e que a participação média do produtor no preço ao atacado, passou de $30,5 \%$ para $26,5 \%$ e, em relação ao preço final, de $48,2 \%$ para $54,3 \%$. Comprando este último resultado com o encontrado por Aguiar et al. (1994), de que na década de 80 a participação do produtor era de $63 \%$, conclui-se a participação deste segmento no preço final do produto reduziu aproximadamente em $10 \%$. 
Tabela 17. Preços médios recebidos pelos produtores dos Estados, no atacado e varejo de São Paulo. Valores em Real, deflacionados para janeiro de 2000.

\begin{tabular}{ccccc}
\hline \multirow{2}{*}{ Estados } & \multicolumn{3}{c}{ Período } & $\begin{array}{c}\text { \% de } \\
\text { Variação(A/B) }\end{array}$ \\
\cline { 2 - 4 } & Jan90-dez99 & Jan90-jun94(A) & Jul94-dez99(B) & Varin \\
RS & 56,04 & 64,19 & 49,37 & $-23,08$ \\
MG & 67,71 & 84,71 & 53,39 & $-36,97$ \\
SP & 69,71 & 84,28 & 57,79 & $-31,43$ \\
PR & 73,40 & 95,14 & 55,61 & $-41,54$ \\
SC & 56,66 & 70,07 & 45,70 & $-34,77$ \\
GO & 53,06 & 63,65 & 44,38 & $-30,27$ \\
\hline & 68,17 & 84,52 & 54,79 & $-35,13$ \\
\hline Produtores & 63,50 & Médias & \\
Atacado & 89,20 & 78,08 & 51,57 & $-33,95$ \\
Varejo & 135,06 & 112,43 & 70,20 & $-33,56$ \\
\hline
\end{tabular}

Fonte: Conab*, Emater-RS*, Informações Econômicas (1990...), Departamento Intersindical de Estatística e Estudos Sócio-Econômicos (1990...), adaptados pelo autor.

* dados de publicações eletrônicas recebidos por e-mail

O trabalho de Junqueira et al. (1971), mostrou que nas décadas de 60 e 70, as variações de preços no mercado de feijão eram duradouras e os períodos de entressafras eram bem definidos. Atualmente, conforme vê-se na Tabela 18, o comportamento sazonal de preços médios mensais recebidos pelos produtores apresenta pouca variação ao longo do ano. Portanto, as variações dos preços são mais freqüentes e com duração mais curta. Esta mudança, provavelmente, está relacionada com a ampliação das épocas de plantio e as contribuições da terceira safra, que foi amplamente instituída, e 
com a maior facilidade de transporte e maior agilidade da estrutura de comercialização.

A estabilidade de preços mensais se repete para os níveis do atacado e varejo (Tabela 18). Nesse sentido, Aguiar et al. (1994) estudando os preços do feijão no período de 1980 a 1992, mostraram que em nenhum nível de mercado ocorreu tendência explosiva de preços. Verificaram, também, que os preços do atacado caminhavam extremamente próximos aos preços recebidos pelos produtores, mas permaneceram afastados dos preços do varejo.

As Figuras 8 a 14 mostram que os preços recebidos pelos produtores apresentaram tendência linear decrescente na década de 90 . Porém a tendência polinomial mostra períodos com tendência de baixa e outros de alta. Comparando o comportamento dessas variações entre os Estados, observa-se que apresentam a mesma tendência de comportamento. Porém, em alguns casos, por exemplo, entre os Estados de São Paulo e Rio Grande do Sul, os preços neste último apresentam maiores variações, portanto, a linha polinomial é mais inclinada, mas possuem a mesma trajetória. Em outros casos, como São Paulo e Santa Catarina, somente após o ano de 1992 os preços começam a variar com intensidade diferente, mas sempre com a mesma propensão de comportamento. 
Tabela 18. Preços médios mensais recebidos pelos produtores dos Estados produtores, preços no atacado e varejo de São Paulo. Período de 1990-99 (saco de 60 quilos de feijão, valores deflacionados para janeiro de 2000).

\begin{tabular}{|c|c|c|c|c|c|c|c|c|c|c|c|c|c|}
\hline Estado & JAN & FEV & MAR & ABR & MAI & JUN & JUL & AGO & SET & OUT & NOV & DEZ & MÉDIA \\
\hline $\mathrm{RS}$ & 59,37 & 56,72 & 56,83 & 53,36 & 55,36 & 59,45 & 55,75 & 54,13 & 55,39 & 56,16 & 55,14 & 54,53 & 56,04 \\
\hline SC & 54,64 & 56,43 & 55,75 & 56,08 & 57,16 & 56,39 & 49,52 & 48,58 & 50,37 & 49,49 & 50,72 & 51,45 & 53,05 \\
\hline PR & 55,09 & 56,56 & 60,95 & 59,54 & 60,30 & 59,87 & 55,25 & 51,90 & 53,12 & 57,32 & 54,97 & 55,08 & 56,66 \\
\hline SP & 73,15 & 78,67 & 84,28 & 85,94 & 82,51 & 75,96 & 66,92 & 62,24 & 64,30 & 72,70 & 69,21 & 64,95 & 73,40 \\
\hline MG & 68,29 & 71,06 & 71,86 & 72,19 & 78,08 & 75,23 & 66,74 & 67,14 & 63,60 & 67,09 & 69,07 & 66,20 & 69,71 \\
\hline GO & 71,23 & 72,64 & 76,43 & 75,33 & 77,11 & 71,53 & 65,92 & 56,96 & 60,94 & 64,76 & 60,83 & 61,27 & 68,17 \\
\hline BA & 67,92 & 79,54 & 76,91 & 74,60 & 76,35 & 71,36 & 66,71 & 56,77 & 61,60 & 66,89 & 56,97 & 54,22 & 67,71 \\
\hline Média & 64,24 & 67,37 & 69,00 & 68,14 & 69,55 & 67,12 & 60,97 & 57,24 & 67,51 & 62,05 & 59,55 & 58,24 & 63,50 \\
\hline Atacado & 79,88 & 94,40 & 98,69 & 94,02 & 79,62 & 77,34 & 69,98 & 68,40 & 70,81 & 81,67 & 76,51 & 67,09 & 79,87 \\
\hline Varejo & 117,60 & 132,64 & 145,05 & 144,76 & 149,11 & 176,54 & 123,01 & 115,68 & 116,44 & 130,85 & 125,36 & 113,69 & 130,06 \\
\hline
\end{tabular}

Fonte: Conab*, Emater-RS*, Informações Econômicas (1990...), Departamento Intersindical de Estatística e Estudos

Sócio-Econômicos (1990...), adaptados pelo autor. 


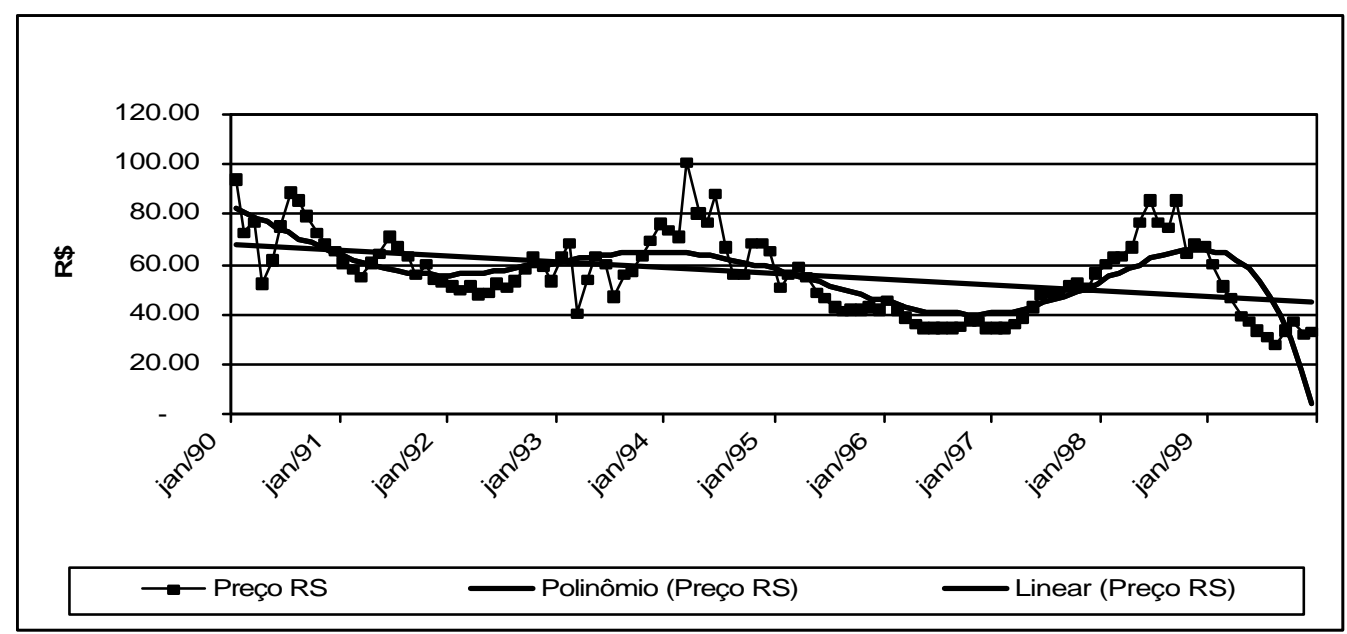

Figura 8 - Comportamento e tendências linear e polinomial dos preços médios recebidos pelos produtores do Rio Grande do Sul, no período de 1990-99.

Fonte: Conab*, Emater-RS*, Informações Econômicas (1990...), adaptados pelo autor. * dados de publicações eletrônicas recebidos por e-mail

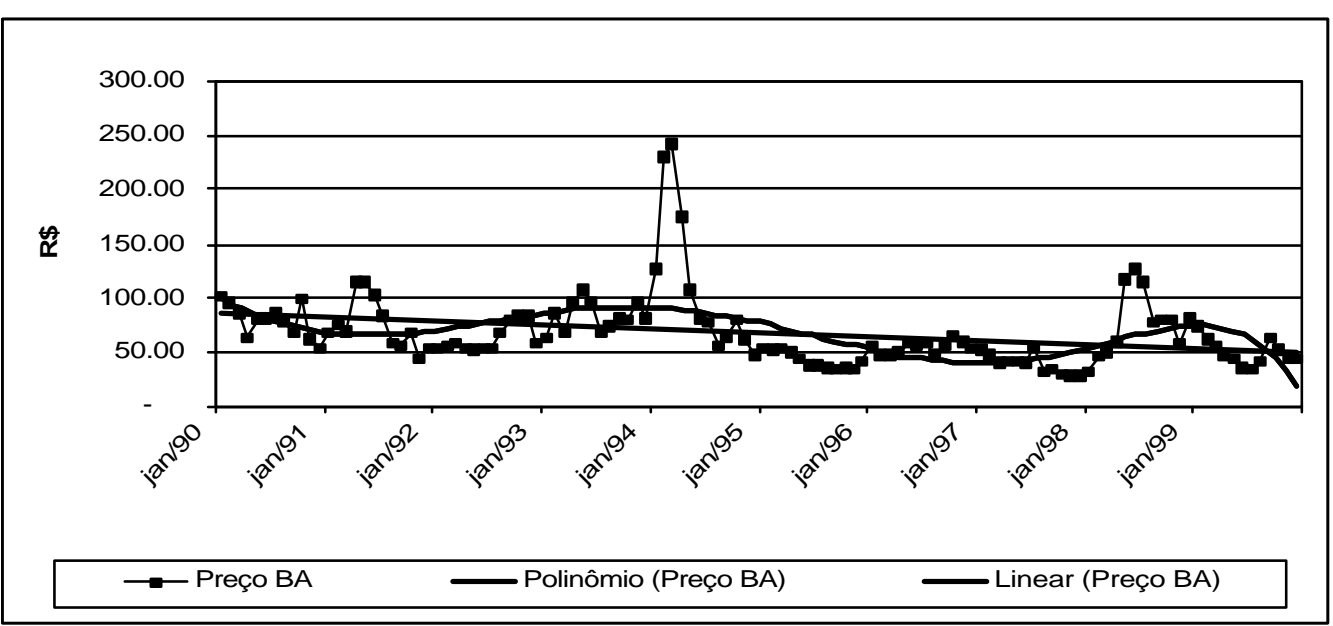

Figura 9 - Comportamento e tendências linear e polinomial dos preços médios recebidos pelos produtores da Bahia, no período de 1990-99.

Fonte: Conab*, Emater-RS*, Informações Econômicas (1990...), adaptados pelo autor. * dados de publicações eletrônicas recebidos por e-mail 


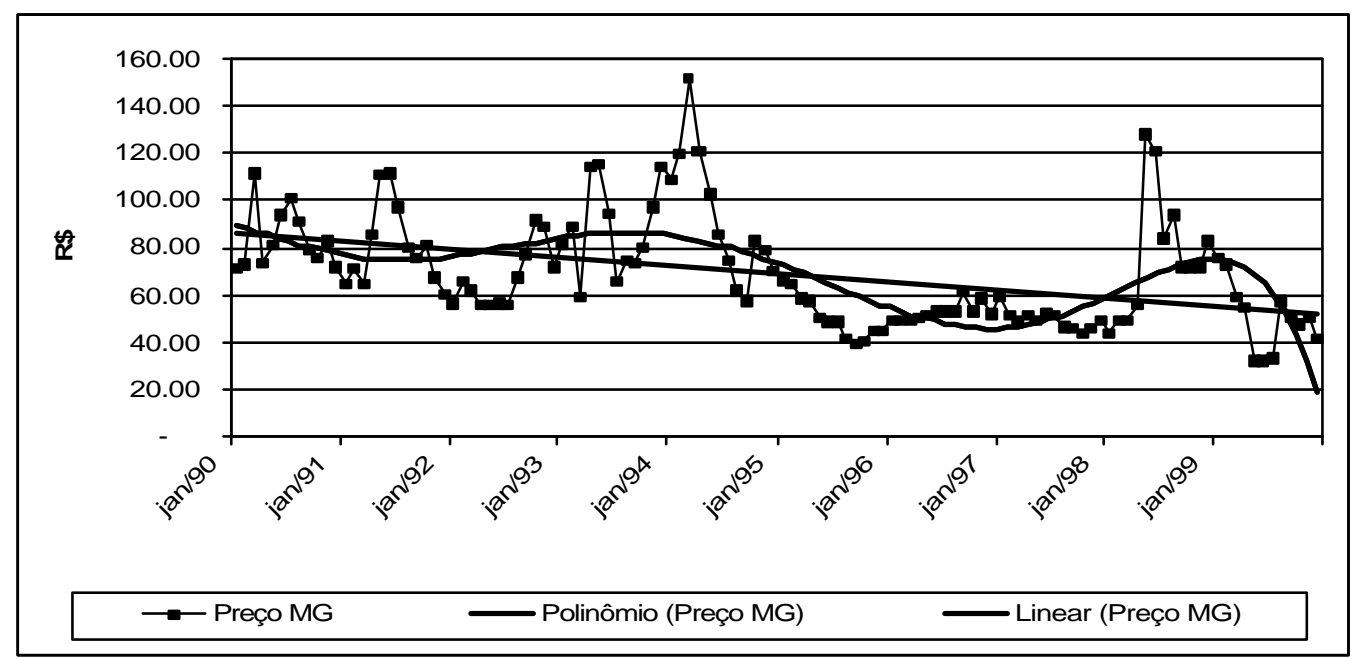

Figura 10 - Comportamento e tendências linear e polinomial dos preços médios recebidos pelos produtores de Minas Gerais, no período de 199099.

Fonte: Conab*, Emater-RS*, Informações Econômicas (1990...), adaptados pelo autor. * dados de publicações eletrônicas recebidos por e-mail

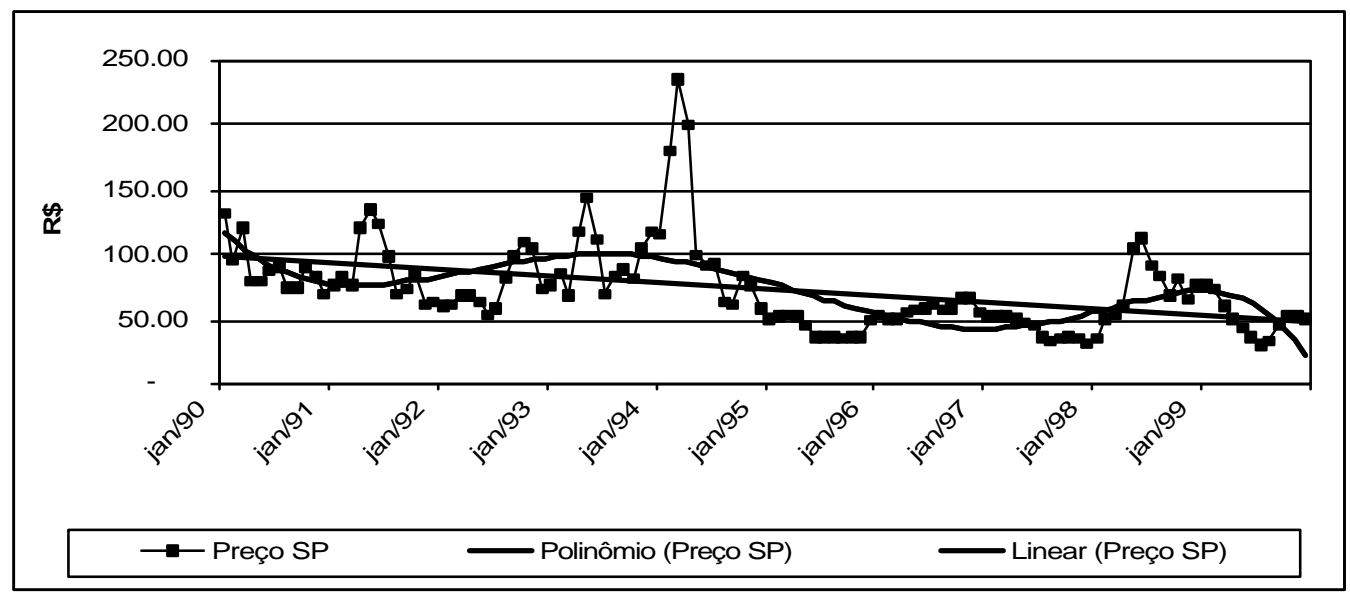

Figura 11 - Comportamento e tendências linear e polinomial dos preços médios recebidos pelos produtores de São Paulo, no período de 1990-99.

Fonte: Conab*, Emater-RS*, Informações Econômicas (1990...), adaptados pelo autor. * dados de publicações eletrônicas recebidos por e-mail 


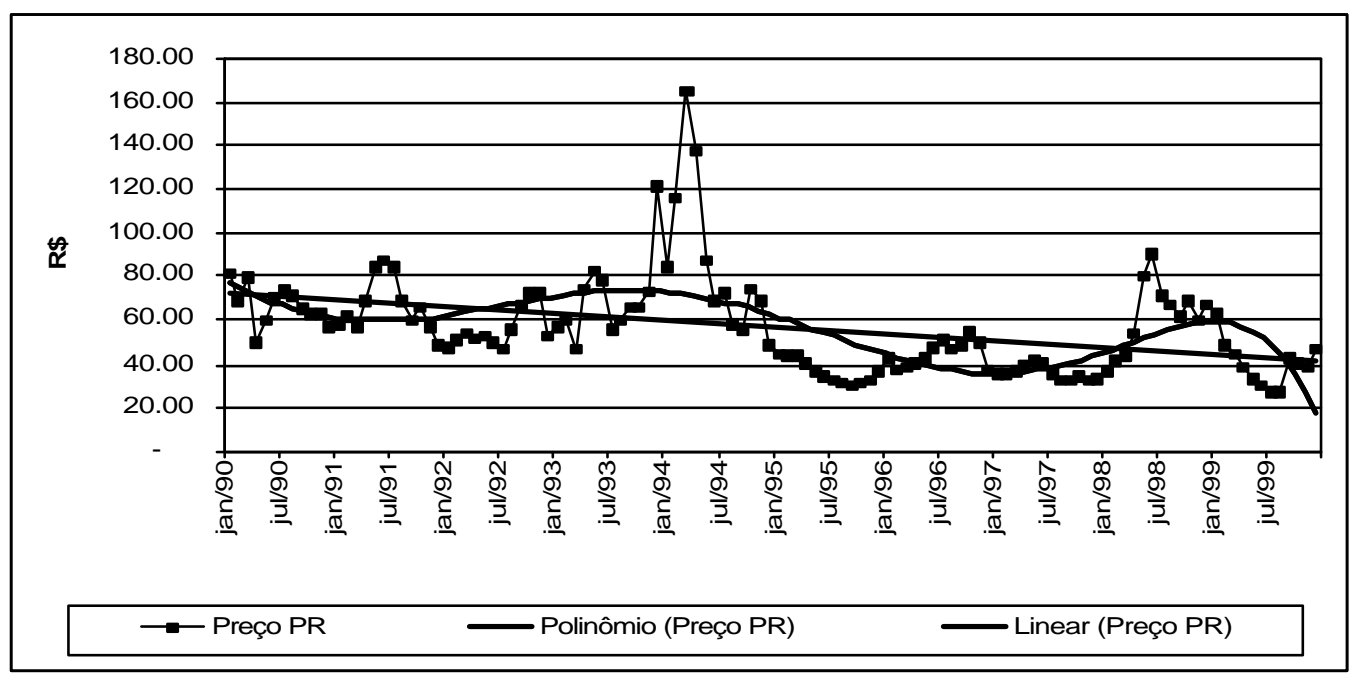

Figura 12 - Comportamento e tendências linear e polinomial dos preços médios recebidos pelos produtores do Paraná, no período de 1990-99.

Fonte: Conab*, Emater-RS*, Informações Econômicas (1990...), adaptados pelo autor. * dados de publicações eletrônicas recebidos por e-mail

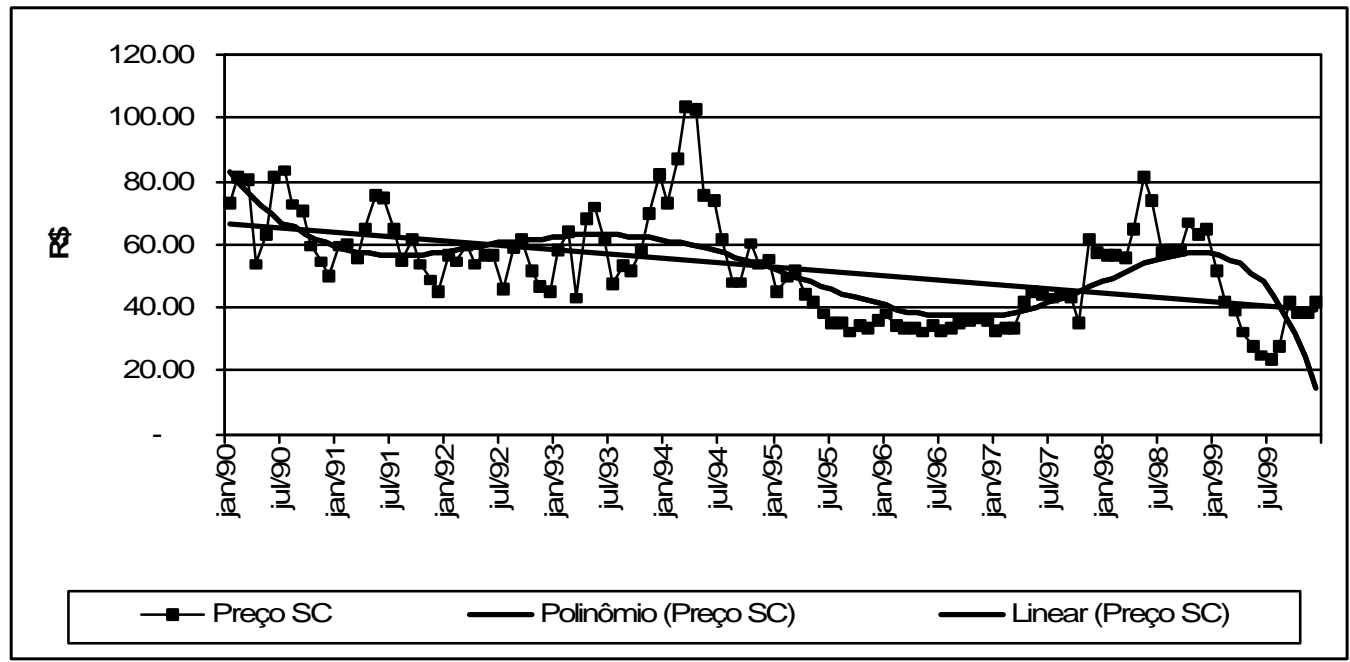

Figura 13 - Comportamento e tendências linear e polinomial dos preços médios recebidos pelos produtores de Santa Catarina, no período de 1990-99

Fonte: Conab*, Emater-RS*, Informações Econômicas (1990...), adaptados pelo autor. * dados de publicações eletrônicas recebidos por e-mail 


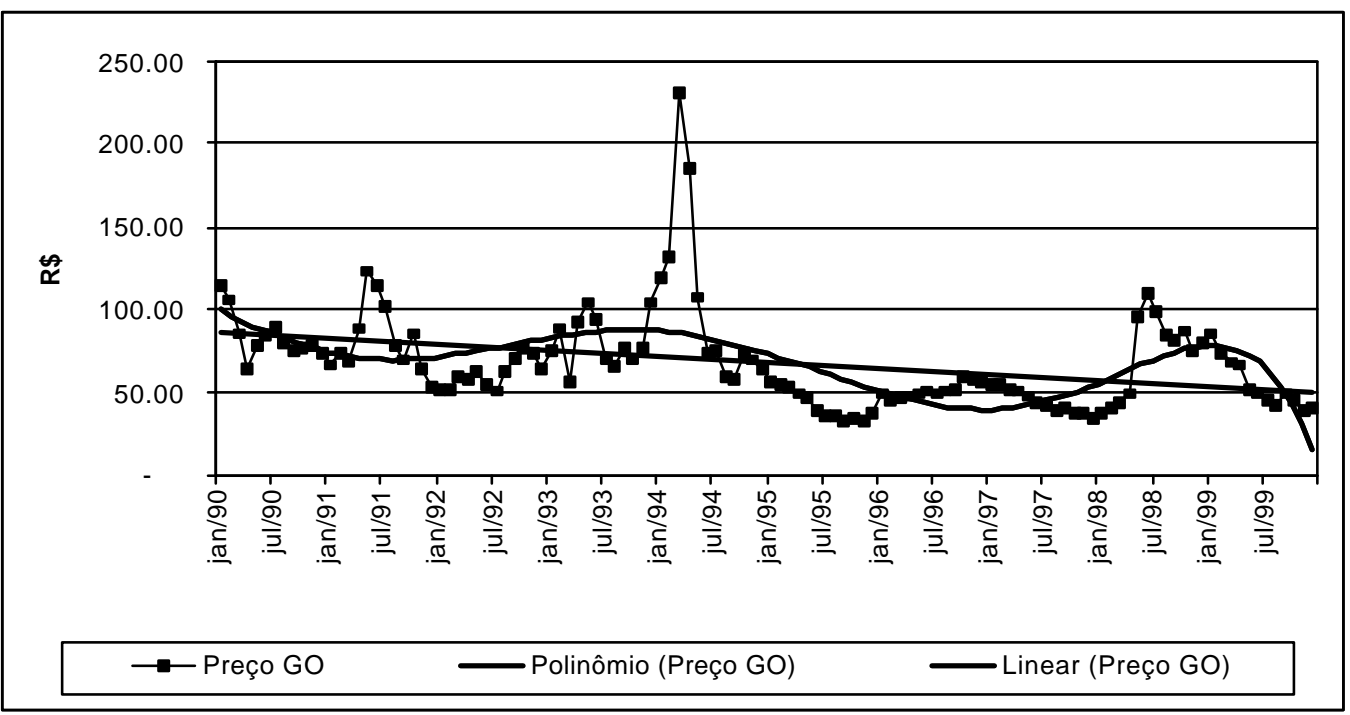

Figura 14 - Comportamento e tendências linear e polinomial dos preços médios recebidos pelos produtores de Goiás, no período de 1990-99.

Fonte: Conab*, Emater-RS*, Informações Econômicas (1990...), adaptados pelo autor. * dados de publicações eletrônicas recebidos por e-mail

\subsection{Considerações sobre fluxo.}

Segundo Tsunechiro et al. (1996), a partir de 1955, ocorreu um desenvolvimento acelerado do comércio na forma de auto-serviços, o binômio "balconista-consumidor" passou ao binômio "mercadoria-consumidor". A expressão máxima desta mudança são as grandes unidades varejistas, os hiper e supermercados que ganharam importância na distribuição e comercialização de produtos alimentícios. Um indicativo da veracidade desta afirmativa é o fato que atualmente este tipo de estabelecimento é encontrado em praticamente todas as regiões do país, independente do Estado e tamanho da cidade. Para Silva (1996), esta mudança contribuiu para reduzir o número de agentes intermediários no processo de distribuição dos produtos agrícolas. Outra conseqüência foi que, em busca de maior competitividade os varejistas 
modernizaram os pontos de vendas, induziram os fornecedores a criarem alternativas de apresentação do produto e, sobretudo, passaram a oferecer produtos com melhor qualidade. Em outras palavras, foram demandados mais e melhores serviços na intermediação.

\subsection{Estudo das margens de comercialização}

Os resultados encontrados para as margens absoluta e relativa do atacado são mostrados na Tabela 19. Comparando o comportamento das margens absolutas nos períodos de janeiro/90 a junho/94 e de julho/94 a dezembro/99, observa-se que, com exceção de São Paulo, onde ocorreu um acréscimo de 1,7\%, nos demais Estados a margem sofreu redução. $O$ valor médio da margem absoluta antes do Plano Real era de $\mathrm{R} \$ 34,35$ e após passou para $R \$ 19,05$, uma redução de aproximadamente $44 \%$. Em termos relativos, somente o Estado de São Paulo sofreu um aumento de $32 \%$. Nos demais, ocorreu redução, só que de pequena magnitude, o valor médio antes do Plano era de $28,4 \%$ e após $26,0 \%$. Desta forma a redução média foi de cerca de $2,7 \%$. Portanto, a margem relativa tendeu a ser preservada.

A questão de preservação da margem pode explicar alguns efeitos e ineficiências com as políticas de tabelamentos de preços. Se a tendência é manter a margem dos varejistas, isso significa que outros segmentos devem estar perdendo, deduz-se, como conseqüência lógica, então que quem está perdendo vai parar de produzir ou buscar alguma forma de boicotar a política. Foi isso que aconteceu nos tabelamentos dos Planos Collor I e II.

Comparando os valores das margens com os encontrados por Barros \& Martines Filho (1990) no período de 1975 - 1984, com zero defasagem e valor máximo, para os Estados do Paraná e São Paulo (Tabela 5), observa-se que em ambos os casos ocorreu aumento da margem, porém, em 
relação ao primeiro a modificação foi maior. Portanto, o consumidor paulista pagou mais pelo serviço de intermediação pelo feijão do Paraná.

Tabela 19. Margem de comercialização absoluta (em Reais, valores deflacionados para janeiro de 2000) e relativa do atacado.

\begin{tabular}{ccccc}
\hline \multirow{2}{*}{ Estado } & \multirow{2}{*}{ Margens } & \multicolumn{3}{c}{ Período } \\
\cline { 3 - 5 } & & Jan/90/dez99 & Jan/90/jun94 & Jul94/dez99 \\
\hline \multirow{2}{*}{ RS } & Absoluta & 33,17 & 48,25 & 20,83 \\
& Relativa & 32,51 & 37,43 & 29,86 \\
\hline \multirow{2}{*}{ BA } & Absoluta & 21,72 & 27,72 & 16,81 \\
& Relativa & 24,46 & 26,90 & 23,15 \\
\hline \multirow{2}{*}{ MG } & Absoluta & 19,49 & 28,15 & 12,41 \\
& Relativa & 18,76 & 20,81 & 17,65 \\
\multirow{2}{*}{ SP } & Absoluta & 15,80 & 17,29 & 17,59 \\
& Relativa & 18,06 & 14,95 & 19,74 \\
\multirow{2}{*}{ PR } & Absoluta & 37,54 & 42,37 & 24,51 \\
& Relativa & 35,18 & 36,49 & 34,48 \\
\hline \multirow{2}{*}{ SC } & Absoluta & 36,16 & 48,79 & 25,82 \\
& Relativa & 37,11 & 38,65 & 36,28 \\
\hline \multirow{2}{*}{ GO } & Absoluta & 21,04 & 27,91 & 15,41 \\
& Relativa & 21,97 & 23,61 & 21,09 \\
\hline
\end{tabular}

A margem total é a proporção das despesas que os consumidores pagam em função da intermediação. Assim, pela Tabela 20, verifica-se que após o Plano Real essas despesas, em termos absolutos, reduziram-se cerca de $17,1 \%$, o valor médio passou de $72,9 \%$ para $61,3 \%$. Ressalta-se que São Paulo, diferente dos demais Estados aumentou cerca de 2,6\%. Em termos relativos ocorreu uma tendência de aumento, passou de 
$48,80 \%$ para $54,04 \%$. Isso pode ser explicado pela maior exigência do consumidor e pelas mudanças no mercado varejista.

Tabela 20 Margem de comercialização total e total relativa (em Reais, valores deflacionados para janeiro de 2000).

\begin{tabular}{ccccc}
\hline \multirow{2}{*}{ Estado } & \multirow{2}{*}{ Margens } & \multicolumn{3}{c}{ Período } \\
\cline { 3 - 5 } & & Jan/90-dez/99 & Jan/90-jun/94 & Jul94-dez/99 \\
\multirow{2}{*}{ RS } & Total & 74,02 & 86,81 & 63,56 \\
& Relativa & 54,81 & 54,55 & 55,03 \\
\hline \multirow{2}{*}{ BA } & Total & 62,58 & 66,28 & 59,54 \\
& Relativa & 49,08 & 43,94 & 53,29 \\
\hline \multirow{2}{*}{ MG } & Total & 60,36 & 66,72 & 55,14 \\
& Relativa & 45,40 & 41,79 & 48,35 \\
\multirow{2}{*}{ SP } & Total & 56,56 & 55,85 & 57,32 \\
& Relativa & 44,48 & 36,47 & 51,03 \\
\hline \multirow{2}{*}{ PR } & Total & 73,40 & 80,93 & 67,24 \\
& Relativa & 56,27 & 52,30 & 59,51 \\
\hline \multirow{2}{*}{ SC } & Total & 77,01 & 87,35 & 68,56 \\
& Relativa & 57,69 & 55,31 & 59,63 \\
\hline \multirow{2}{*}{ GO } & Total & 61,90 & 66,48 & 58,15 \\
& Relativa & 47,76 & 43,27 & 51,44 \\
\hline
\end{tabular}

Ao contrário do que aconteceu na margem total, cujos valores absolutos cresceram e os relativos reduziram-se, na margem de comercialização entre os níveis do atacado e varejo, houve aumento tanto em valores absolutos como valores relativos (Tabela 21). Porém, em valores absolutos, o aumento foi em torno de $23 \%$ e relativo $53 \%$. A explicação para tal fato é a mesma apresentada para a margem total. 
Tabela 21. Margem de comercialização absoluta (em Reais, valores deflacionados para janeiro de 2000) e relativa do varejo.

\begin{tabular}{cccc}
\hline \multirow{2}{*}{ Margens } & \multicolumn{3}{c}{ Período } \\
\cline { 2 - 4 } & Jan90/dez99 & Jan90/jun94 & Jul94/dez99 \\
\hline Absoluto & 40,86 & 37,01 & 45,56 \\
Relativa & 31,91 & 24,72 & 37,80 \\
\hline
\end{tabular}

Na Tabela 22 verifica-se, considerando o período de 1990 a 1999, o comportamento e sazonalidade das margens de comercialização. A margem relativa do atacado, no período de janeiro/90 a junho/94, apresenta sua menor média no mês de janeiro e a maior em outubro. Este resultado é coerente com o mercado, pois em janeiro ocorre alto índice de colheita $(13,4 \%)$ e em outubro ocorre o menor índice (0,9\%). Após julho/94, o menor valor dessa margem passa a ocorrer em setembro e o maior continua em outubro. A explicação pode estar relacionada com a fato de o Estado de São Paulo ter reduzido sua produção e de o Nordeste ter aumentado a sua. Desta forma, passou a exercer menor pressão no mercado do sul do País entre julho e setembro.

Antes de junho/94, a margem relativa do varejo apresentava os maiores valores nos meses de janeiro e maio. Após essa data, ocorreu, de maneira geral, uma tendência de aumento, sendo que os maiores valores ocorreram nos meses de maio e junho. Nesta época do ano é comercializada a segunda safra. Assim sendo, uma possível causa do aumento da margem pode ser atribuída ao efeito Nordeste, porque nesta época o mercado varejista começava a estocar produto, precavendo-se para abastecer o mercado nordestino, contudo, com a maior estabilidade e maior produção nesta região, sobrou produto no sul. Consequentemente os preços para os produtores e atacadistas reduziram-se, mas o varejo manteve os preços, aumentando a margem. 
Tabela 22. Médias mensais das margens de comercialização de feijão total e absoluta (valores deflacionados para janeiro de 2000) e relativa do atacado, do varejo e total. Saco de 60 quilos.

\begin{tabular}{|c|c|c|c|c|c|c|c|c|c|c|c|c|c|c|}
\hline \multicolumn{2}{|c|}{ Margem } & Período & JAN & FEV & MAR & ABR & $\mathrm{MAI}$ & JUN & JUL & AGO & SET & OUT & NOV & DEZ \\
\hline$A$ & Abs & Jan/90-dez/99 & 21,31 & 33,82 & 36,78 & 35,35 & 24,59 & 23,81 & 19,29 & 19,94 & 21,50 & 29,04 & 24,47 & 18,53 \\
\hline \multirow{2}{*}{$\mathrm{T}$} & \multirow{2}{*}{$(4)$} & Jan/90-jun/94 & 25,07 & 47,41 & 53,52 & 49,46 & 27,63 & 29,78 & 21,43 & 26,19 & 27,34 & 37,35 & 35,76 & 24,62 \\
\hline & & Jul/94-dez/99 & 17,56 & 20,23 & 20,04 & 21,25 & 21,55 & 17,85 & 26,71 & 16,74 & 16,00 & 29,36 & 21,49 & 19,20 \\
\hline A & Rel & Jan/90-dez/99 & 24,20 & 30,79 & 32,60 & 31,17 & 24,87 & 25,19 & 22,86 & 24,58 & 25,20 & 30,54 & 27,10 & 23,26 \\
\hline \multirow{2}{*}{ (1) } & \multirow{2}{*}{ (5) } & Jan/90-jun/94 & 23,50 & 33,04 & 36,20 & 33,96 & 23,62 & 26,15 & 23,75 & 25,52 & 27,19 & 33,02 & 32,21 & 26,56 \\
\hline & & Jul/94-dez/99 & 24,91 & 28,54 & 29,00 & 28,38 & 26,12 & 24,24 & 28,39 & 25,26 & 21,44 & 32,18 & 27,92 & 28,12 \\
\hline $\mathrm{V}$ & Abs & Jan/90-dez/99 & 42,05 & 31,45 & 39,27 & 41,26 & 54,93 & 45,61 & 42,75 & 38,50 & 36,47 & 39,76 & 41,34 & 36,91 \\
\hline \multirow{2}{*}{ A } & & Jan/90-jun/94 & 46,00 & 24,83 & 37,34 & 50,99 & 60,24 & 38,45 & 38,22 & 33,98 & 31,15 & 32,60 & 33,49 & 28,81 \\
\hline & & Jul/94-dez/99 & 38,09 & 38,07 & 41,20 & 31,53 & 49,63 & 52,76 & 33,81 & 37,03 & 35,69 & 29,57 & 33,76 & 27,77 \\
\hline $\mathrm{R}$ & Rel & Jan/90-dez/99 & 32,61 & 25,07 & 26,93 & 28,99 & 35,75 & 33,82 & 35,39 & 33,65 & 32,48 & 31,18 & 34,06 & 33,05 \\
\hline \multirow{2}{*}{ (2) } & \multirow{2}{*}{ (5) } & Jan/90-jun/94 & 30,04 & 16,82 & 17,49 & 26,75 & 31,06 & 25,32 & 28,13 & 26,25 & 24,23 & 22,53 & 24,30 & 23,94 \\
\hline & & Jul/ & 35,17 & 33 & 36,37 & 31,22 & 40,43 & 42,33 & 31,86 & 37,70 & 38,51 & 28,68 & 32,87 & 28,36 \\
\hline $\bar{T}$ & \multirow{3}{*}{ Total } & Jan/90-dez/99 & 63,36 & 65,27 & 76,05 & 76,61 & 79,52 & 69,42 & 62,04 & 58,44 & 57,97 & 68,80 & 65,80 & 55,45 \\
\hline \multirow{2}{*}{$\mathrm{O}$} & & Jan/90-jun/94 & 71,07 & 72,24 & 90,87 & 100,45 & 87,86 & 68,23 & 59,65 & 60,17 & 58,50 & 69,95 & 69,26 & 53,44 \\
\hline & & Jul/94-dez/99 & 55,65 & 58,30 & 61,24 & 52,78 & 71,17 & 70,61 & 60,52 & 53,77 & 51,70 & 58,93 & 55,24 & 46,97 \\
\hline $\mathrm{T}$ & Rel & Jan/90-dez/99 & 46,85 & 47,30 & 48,65 & 47,61 & 48,18 & 47,65 & 48,31 & 46,47 & 46,96 & 47,79 & 49,07 & 45,32 \\
\hline \multirow[t]{2}{*}{ (3) } & \multirow{2}{*}{ (5) } & Jan/90-jun/94 & 45,65 & 44,81 & 46,67 & 48,06 & 44,58 & 42,24 & 42,90 & 42,84 & 42,50 & 45,85 & 47,33 & 42,11 \\
\hline & & Jul/94-dez/99 & 48,05 & 49,80 & 50,64 & 47,17 & 51,78 & 53,06 & 48,91 & 48,21 & 50,24 & 48,96 & 47,72 & 43,49 \\
\hline
\end{tabular}

(1) atacado; (2) varejo; (3) total; (4) absoluto; (5) relativo 
Algumas ponderações se fazem necessárias antes de concluir o assunto margens de comercialização. Primeiramente, deve-se considerar que as séries de preços utilizadas não refletem os preços de um mesmo lote de produto, desde o produtor até o mercado varejista. Assim, podem ocorrer erros em função de os produtos poderem ter preços diferentes devido à sua origem e devido ao desconhecimento do período que o produto levou para ser vendido no varejo. A segunda observação é que a série de preços ao atacado refere-se ao feijão com classificação do tipo I e, nos demais níveis de mercado refletem os preços médios das diversas classificações. Portanto, os preços ao varejo podem estar supervalorizados em relação aos demais níveis. O terceiro viés está relacionado com a equivalência do produto, ou seja, não foram consideradas perdas no beneficiamento. Portanto, os valores de margens encontrados estão super dimensionados. Estes problemas não comprometem a validade das análises.

\subsection{Estudo econométrico}

O resultado da determinação do número de defasagens é apresentado na Tabela A5 (anexo) e os resultados do teste de raiz unitária podem ser vistos na Tabela A6, A7, A8 e A9 (anexo). O teste detectou a presença de raiz unitária em todas variáveis, com exceção da variável preço ao varejo de São Paulo. Na Tabela A10 (anexo), verifica-se que se tornaram estacionárias após uma diferenciação. Essa medida traz dificuldades para as análises das equações de transmissão de preços, uma vez que os parâmetros não indicam variação percentual, mas uma taxa de crescimento de preços.

Os testes de co-integração avaliaram as relações de preços médios mensais recebidos pelos produtores dos sete principais Estados produtores, bem como as relações entre estes preços e os preços nos mercados atacadista e varejista de São Paulo. Na Tabela A11(anexo), observa- 
se que ao nível de 10\% de significância, todas relações foram co-integradas. Portanto, os preços recebidos pelos produtores dos Estados têm relacionamento de longo prazo. Isto significa que existe interação entre os níveis de mercado.

A correlação, de acordo Gujarati (1995), mede a intensidade ou grau de associação linear entre duas variáveis. Na Tabela A12 (anexo), observa-se que são fortes as correlações contemporâneas entre os preços recebidos pelos produtores nos Estados e entre estes e os preços nos mercados varejista e atacadista de São Paulo. Cerca de $20 \%$ dessas relações também são significativas no primeiro mês. Nota-se ainda, que no quinto e décimo segundo mês as relações significativas são negativas. Este resultado pode ser explicado pelo fato de a defasagem com cinco meses coincidir com o período que os produtores estão tomando decisões sobre o plantio e, com doze meses, sugere a concluir que o produtor trabalha com expectativa de preço do ano anterior. Desta forma, quando os preços nestes meses são altos, os produtores são estimulados a plantarem uma maior área ou aplicar mais tecnologia em busca de melhores produções. Assim, a oferta aumenta reduzindo os preços na época da colheita.

Os testes de causalidade foram feitos com nível de significância de 10\%. A Tabela A13 (anexo) apresenta os valores encontrados e o nível de significância dos testes. Esperava-se que devido a importância da produção e da sincronia das safras dos Estados produtores no abastecimento nacional, fossem determinadas muitas relações de causalidade, mas foram encontradas somente as relações mostradas na Figura 15. A justificativa para o baixo número pode estar relacionada com o fato de que os preços utilizados foram médias mensais, como as informações sobre preços pagos aos produtores são disseminadas rapidamente no mercado, e, normalmente, as variação de preços nos Estados ocorrem em períodos menores do que um mês, possivelmente 
estas instabilidades não foram captadas. Outro argumento, talvez o mais importante, é que o teste de causalidade foi feito considerando a série temporal com dados mensais e o ideal seria considerar a seqüência real de épocas de colheitas das regiões. Os principais resultados visualizados na Figura 16 são; que o sentido predominante da causalidade é do atacado para os produtores e do atacado para o varejo.

Na Tabela A13 (anexo), mostram-se também os valores do teste "Q", que tem como hipótese de nulidadade a ausência de autocorrelação do erro. Os resultados indicam que as séries não apresentam este problema.

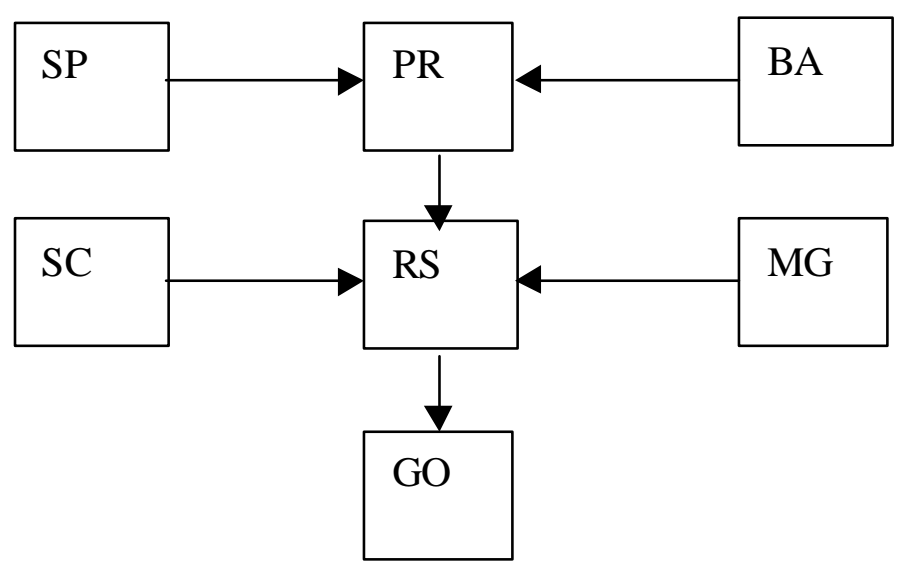

Figura 15-Relações de causalidade entre os preços recebidos pelos produtores dos Estados produtores. 


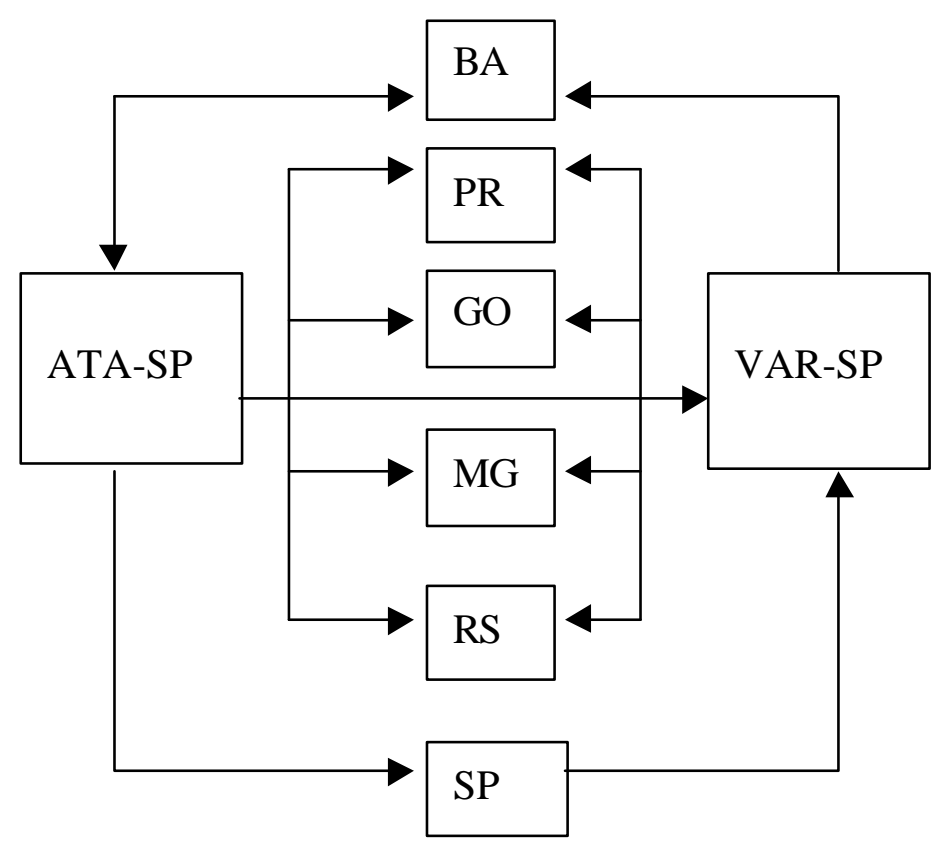

Figura 8 - Relações de causalidade entre os Estados e os mercados atacadista e varejista de São Paulo.

\subsection{Estudo da transmissão de preços}

Conforme discutido anteriormente, para estimar a elasticidade de transmissão de preços foi utilizado o modelo proposto por Barros (1990). Os resultados da causalidade corroboram a aplicação deste modelo, pois ficou evidenciada a validade do pressuposto de que o nível de atacado é o líder, ou seja, as variações ocorrem do atacado para o varejo e do atacado para o produtores.

$\mathrm{Na}$ Tabela 23 vê-se os valores encontrados para a equação de transmissão de preços do atacado para o varejo. Os coeficientes da constante não foram significativos no nível de significância de $5 \%$. A variável preço ao varejo defasada um mês também não foi significativa nos dois sub períodos. 
Neste caso, somente foi considerada a elasticidade de curto prazo ${ }^{39}$. A variável preço dos insumos de comercialização apresentou um péssimo desempenho, pois o salário mínimo e o óleo diesel não apresentaram efeitos significativos. Este tipo de resultado tem-se repetido em vários trabalhos. Por exemplo, no trabalho de Barros (1990), o desempenho destas variáveis foi considerado sofrível.

Tabela 23. Equação de transmissão de preços de feijão - Atacado/varejo.

\begin{tabular}{ccccccc}
\hline Período & Constante & $\begin{array}{c}\text { Preço } \\
\text { Varejo }_{-1}\end{array}$ & $\begin{array}{c}\text { Preço } \\
\text { Atacado }\end{array}$ & $\begin{array}{c}\text { Salário } \\
\text { Mínimo }\end{array}$ & Diesel & $R^{2}$ \\
\hline \multirow{2}{*}{ Jan/90 - dez/99 } & 0,201 & $0,119^{*}$ & $0,955^{*}$ & 0,096 & $-4,954$ & 0,64 \\
& $(0,13)$ & $(2,10)$ & $(13,24)$ & $(1,57)$ & $(-0,23)$ & \\
\multirow{2}{*}{ Jan/90 - jun/94 } & 0,619 & 0,088 & $0,909^{*}$ & 0,083 & 4,36 & 0,65 \\
& $(0,170)$ & $(0,930)$ & $(8,51)$ & $(0,98)$ & $(0,147)$ & \\
\multirow{2}{*}{ Jul/94 - dez/99 } & 0,162 & 0,126 & $0,913^{*}$ & 0,078 & 3,788 & 0,66 \\
& $(0,056)$ & $(1,65)$ & $(9,86)$ & $(1,05)$ & $(0,144)$ & \\
\hline
\end{tabular}

Entre parênteses estão os valores da estatística t.

* significativo a $1 \%$

** significativo a $5 \%$

A Tabela 24 apresenta os resultados das elasticidades de transmissão entre os níveis de mercado do atacado e do varejo e o período de tempo, em meses, para que ocorra $95 \%$ do ajustamento dos preços. Observase que a transmissão total, no período de 1990/99 e no período janeiro/90 a junho/94, foram iguais e, no segundo período, foi menor, sendo o tempo de ajuste no mês contemporâneo. Na Tabela verifica-se que antes do Plano Real

${ }^{39}$ demonstração: se $1-\beta=0$, então $\beta=1$. Assim, $\frac{\beta}{c_{1}}=\frac{1}{c_{1}}$ 
uma elevação de $10 \%$ nos preços ao atacado causava uma elevação de 7,4\% no preço do varejo e após o Plano o impacto reduziu-a para 6,4\%.

Tabela 24. Estimativa das elasticidades de transmissão de preços parciais e totais - Atacado/varejo, período 1990-99.

\begin{tabular}{cccc}
\hline \multirow{2}{*}{ Período } & \multicolumn{2}{c}{ Elasticidade } & $\begin{array}{c}\text { Tempo } \\
\text { (meses) }\end{array}$ \\
\cline { 2 - 3 } & Total & Parcial $^{\star}$ & 1,40 \\
\hline Jan/90 - dez/99 & 0,74 & 0,08 & \\
Jan/90 - jun/94 & 0,74 & & \\
Jul/94 - dez/99 & 0,64 & & \\
\hline
\end{tabular}

${ }^{\text {* }}$ parcial = ajuste acumulado após o mês contemporâneo.

A Tabela 25 apresenta os resultados da equação de transmissão de preços entre 0 atacado e os produtores. Os parâmetros da constante também não foram significativos e os parâmetros da variável preço ao produtor, defasado um mês, só foi significativo nas relações entre os Estados do Paraná e São Paulo. Nos sub-períodos, somente o Estado de São Paulo apresentou valores significativos. Novamente, a variável preço dos insumos de comercialização apresentou problema de desempenho, verificandose que, nesse particular, a relação das variáveis salário mínimo e o óleo diesel apresentaram efeitos significativos somente em alguns Estados e períodos isolados. 
Tabela 25. Equação de transmissão de preços de feijão - Atacado produtor.

\begin{tabular}{|c|c|c|c|c|c|c|c|}
\hline Estado & Período & Constante & Produtor $_{\mathrm{t}-1}$ & Atacado & $\begin{array}{l}\text { Salário } \\
\text { Mínimo } \\
\end{array}$ & Diesel & $\mathrm{R}^{2}$ \\
\hline \multirow{3}{*}{ RS } & Jan/90 -dez/99 & $\begin{array}{c}-0,203 \\
(-0,346)\end{array}$ & $\begin{array}{l}-0,063 \\
(0,804)\end{array}$ & $\begin{array}{l}0,112^{*} \\
(4,383)\end{array}$ & $\begin{array}{c}0,034 \\
(1,713)\end{array}$ & $\begin{array}{c}20,555^{\star} \\
(2,959)\end{array}$ & 0,34 \\
\hline & Jan/90 -jun/94 & $\begin{array}{c}0,170 \\
(0,162)\end{array}$ & $\begin{array}{c}-0,055 \\
(-0,487)\end{array}$ & $\begin{array}{l}0,091^{*} \\
(3,00)\end{array}$ & $\begin{array}{c}0,026 \\
(1,097)\end{array}$ & $\begin{array}{c}20,86^{\star *} \\
(2,43)\end{array}$ & 0,41 \\
\hline & Jul/94 - dez/99 & $\begin{array}{c}-0.136 \\
(-0,145)\end{array}$ & $\begin{array}{c}-0,051 \\
(-0,517)\end{array}$ & $\begin{array}{l}0,095^{*} \\
(3,23)\end{array}$ & $\begin{array}{l}0,031 \\
(1,30)\end{array}$ & $\begin{array}{r}22,52^{*} \\
(2,69) \\
\end{array}$ & 0.39 \\
\hline \multirow{3}{*}{ SC } & Jan/90 -dez/99 & $\begin{array}{c}-0,158 \\
(-0,267)\end{array}$ & $\begin{array}{c}-0,048 \\
(-0,701)\end{array}$ & $\begin{array}{l}0,197^{*} \\
(8,306)\end{array}$ & $\begin{array}{l}0,054^{*} \\
(2,652)\end{array}$ & $\begin{array}{c}7,001 \\
(1,014)\end{array}$ & 0,47 \\
\hline & Jan/90 -jun/94 & $\begin{array}{c}-0,021 \\
(-0,019)\end{array}$ & $\begin{array}{c}-0,049 \\
(-0,450)\end{array}$ & $\begin{array}{l}0,179^{*} \\
(5,649)\end{array}$ & $\begin{array}{c}0,049 \\
(1,932)\end{array}$ & $\begin{array}{c}7,710 \\
(0,896)\end{array}$ & 0,52 \\
\hline & Jul/94 - dez/99 & $\begin{array}{c}-0,370 \\
(-0,410) \\
\end{array}$ & $\begin{array}{c}-0,045 \\
(-0,505) \\
\end{array}$ & $\begin{array}{l}0,182^{*} \\
(6,413)\end{array}$ & $\begin{array}{l}0,052^{\star *} \\
(2,263) \\
\end{array}$ & $\begin{array}{c}8,20 \\
(1,03) \\
\end{array}$ & 0,52 \\
\hline \multirow{3}{*}{ PR } & Jan/90 -dez/99 & $\begin{array}{c}0,076 \\
(0,110)\end{array}$ & $\begin{array}{l}0,150^{*} \\
(2,665)\end{array}$ & $\begin{array}{c}0,398^{*} \\
(14,227)\end{array}$ & $\begin{array}{c}0,008 \\
(0,361)\end{array}$ & $\begin{array}{c}1,457 \\
(0,178)\end{array}$ & 0,65 \\
\hline & Jan/90 -jun/94 & $\begin{array}{c}0,206 \\
(0,134)\end{array}$ & $\begin{array}{c}0,111 \\
(1,085)\end{array}$ & $\begin{array}{l}0,376^{*} \\
(8,36)\end{array}$ & $\begin{array}{c}0,008 \\
(0,230)\end{array}$ & $\begin{array}{c}3,51 \\
(0,288)\end{array}$ & 0,62 \\
\hline & Jul/94 - dez/99 & $\begin{array}{c}-0,014 \\
(-0,012) \\
\end{array}$ & $\begin{array}{l}0,145 \\
(1,83) \\
\end{array}$ & $\begin{array}{l}0,388^{*} \\
(10,02)\end{array}$ & $\begin{array}{c}0,006 \\
(0,210) \\
\end{array}$ & $\begin{array}{c}2,74 \\
(0,254) \\
\end{array}$ & 0,64 \\
\hline \multirow{3}{*}{ SP } & Jan/90 -dez/99 & $\begin{array}{c}0,126 \\
(0,774)\end{array}$ & $\begin{array}{l}0,144^{*} \\
(3,722)\end{array}$ & $\begin{array}{c}0,640^{*} \\
(22,031)\end{array}$ & $\begin{array}{l}0,061^{\star *} \\
(2,480)\end{array}$ & $\begin{array}{c}4,925 \\
(0,568)\end{array}$ & 0,83 \\
\hline & Jan/90 -jun/94 & $\begin{array}{c}-0,139 \\
(-0,092)\end{array}$ & $\begin{array}{c}0,177^{\star *} \\
(2,58)\end{array}$ & $\begin{array}{l}0,642^{*} \\
(14,64)\end{array}$ & $\begin{array}{l}0,060 \\
(1,72)\end{array}$ & $\begin{array}{c}6,18^{*} \\
(12,33)\end{array}$ & 0,85 \\
\hline & Jul/94 - dez/99 & $\begin{array}{c}0,119 \\
(0,099) \\
\end{array}$ & $\begin{array}{l}0,134^{*} \\
(2,62)\end{array}$ & $\begin{array}{c}0,642 \\
(16,78)\end{array}$ & $\begin{array}{l}0,059 \\
(1,94)\end{array}$ & $\begin{array}{c}5,26 \\
(0,48) \\
\end{array}$ & 0,85 \\
\hline \multirow{3}{*}{ MG } & Jan/90 -dez/99 & $\begin{array}{c}0,042 \\
(0,041)\end{array}$ & $\begin{array}{c}-0,019 \\
(-0,270)\end{array}$ & $\begin{array}{c}0,316 \\
(7,521)\end{array}$ & $\begin{array}{c}0,015 \\
(0,441)\end{array}$ & $\begin{array}{l}35,241^{*} \\
(2,836)\end{array}$ & 0,44 \\
\hline & Jan/90 -jun/94 & $\begin{array}{c}0,709 \\
(0,417)\end{array}$ & $\begin{array}{c}0,018 \\
(0,175)\end{array}$ & $\begin{array}{c}0,253 \\
(5,171)\end{array}$ & $\begin{array}{c}0,003 \\
(0,083)\end{array}$ & $\begin{array}{c}43,19^{*} \\
(3,05)\end{array}$ & 0,55 \\
\hline & Jul/94 - dez/99 & $\begin{array}{c}0,291 \\
(0,209) \\
\end{array}$ & $\begin{array}{c}0,047 \\
(0,521)\end{array}$ & $\begin{array}{l}0,264 \\
(6,02) \\
\end{array}$ & $\begin{array}{c}0,004 \\
(0,130) \\
\end{array}$ & $\begin{array}{l}42,17^{*} \\
(3,30)\end{array}$ & 0,54 \\
\hline \multirow{3}{*}{ GO } & Jan/90 -dez/99 & $\begin{array}{c}0,241 \\
(-0,200)\end{array}$ & $\begin{array}{c}0,105 \\
(1,471)\end{array}$ & $\begin{array}{l}0,416^{\star \star} \\
(8,613)\end{array}$ & $\begin{array}{c}0,065 \\
(1,588)\end{array}$ & $\begin{array}{l}-11,121 \\
(-0,785)\end{array}$ & 0,43 \\
\hline & Jan/90 -jun/94 & $\begin{array}{c}0,004 \\
(0,001)\end{array}$ & $\begin{array}{c}-0,002 \\
(-0,018)\end{array}$ & $\begin{array}{c}0,409 \\
(5,237)\end{array}$ & $\begin{array}{l}0,068 \\
(1,10)\end{array}$ & $\begin{array}{c}-11,04 \\
(-0,515)\end{array}$ & 0,40 \\
\hline & Jul/94 - dez/99 & $\begin{array}{c}-0,538 \\
(-0,251)\end{array}$ & $\begin{array}{l}0,075 \\
(0,75) \\
\end{array}$ & $\begin{array}{l}0,407 \\
(6,01) \\
\end{array}$ & $\begin{array}{c}0,064 \\
(1,181) \\
\end{array}$ & $\begin{array}{c}-11,02 \\
(-0,582)\end{array}$ & 0,41 \\
\hline \multirow{3}{*}{ BA } & Jan/90 -dez/99 & $\begin{array}{c}-0,978 \\
(-0,158)\end{array}$ & $\begin{array}{c}-0,078 \\
(-1,293)\end{array}$ & $\begin{array}{c}0,641^{* *} \\
(-13,598)\end{array}$ & $\begin{array}{l}0,076^{\star *} \\
(2,068)\end{array}$ & $\begin{array}{c}27,556^{\star *} \\
(-2,134)\end{array}$ & 0,65 \\
\hline & Jan/90 -jun/94 & $\begin{array}{c}0,329 \\
(0,153)\end{array}$ & $\begin{array}{l}-0,184 \\
(-1,79)\end{array}$ & $\begin{array}{c}0,658 \\
(9,247)\end{array}$ & $\begin{array}{c}0,070 \\
(1,415)\end{array}$ & $\begin{array}{l}-30,18 \\
(-1,72)\end{array}$ & 0,68 \\
\hline & Jul/94 - dez/99 & $\begin{array}{c}-0,431 \\
(-0,248)\end{array}$ & $\begin{array}{c}-0,113 \\
(-1,361)\end{array}$ & $\begin{array}{c}0,636 \\
(10,31)\end{array}$ & $\begin{array}{l}0,073 \\
(1,66)\end{array}$ & $\begin{array}{l}-28,29 \\
(-1,801)\end{array}$ & 0,68 \\
\hline
\end{tabular}

Entre parênteses estão os valores da estatística t.

* significativo a $1 \% \quad$ ** significativo a $5 \%$ 
A Tabela 26 apresenta os resultados das elasticidades de transmissão de preços entre o atacado de São Paulo e os produtores dos principais estados produtores. Quanto ao tempo de ajuste, somente os estados do Paraná e São Paulo apresentaram defasagem para ajustamento; nos demais os ajustes foram imediatos. Quando ocorre uma alteração de $10 \%$ no preço do mercado atacadista de São Paulo, os reajustes para os produtores de Santa Catarina e Minas Gerais são, respectivamente, de 3,1\% e 4,0\%. Enquanto os preços recebidos pelos produtores paranaenses e goianos são reajustados, respectivamente, em $5,7 \%$ e $5,4 \%$. Os preços dos produtores paulistas e baianos são reajustados e, 9,0\% e 8,4\%, portanto, recebem quase a totalidade do impacto. Quanto à divisão em sub-períodos, observa-se que, após o Plano Real, os repasses dos choques foi menor para os produtores dos Estados do Rio Grande do Sul, Santa Catarina, Paraná, Minas Gerais e Bahia. Esta redução foi de tal magnitude que pode ser desprezada, pois antes do Plano Real o valor médio da transmissão nestes Estados era de 0,45 e após o Plano passou para 0,43 . Portanto, correspondeu a uma redução de $0,2 \%$ nos preços recebidos pelos produtores quando ocorria uma variação de $10 \%$ nos preços do atacado. Nos Estados de São Paulo e Goiás, ao contrário, o choque foi acentuado respectivamente e, $0,1 \%$ e $0,4 \%$, para uma variação de $10 \%$ nos preços do atacado. 
Tabela 26. Estimativa das elasticidades de transmissão de preços parciais e totais - Atacado/produtor, período 1990-99.

\begin{tabular}{|c|c|c|c|c|}
\hline \multirow{2}{*}{ Estado } & \multirow{2}{*}{ Período } & \multicolumn{2}{|c|}{ Elasticidade $^{40}$} & \multirow{2}{*}{ Tempc } \\
\hline & & Total & Parcial & \\
\hline \multirow{3}{*}{$\mathrm{RS}$} & Jan/90-dez/99 & 0,17 & & \\
\hline & Jan/90- jun/94 & 0,16 & & \\
\hline & Jul/94- dez/99 & 0,13 & & \\
\hline \multirow{3}{*}{ SC } & Jan/90-dez/99 & 0,31 & & \\
\hline & Jan/90- jun/94 & 0,31 & & \\
\hline & Jul/94- dez/99 & 0,28 & & \\
\hline \multirow{3}{*}{ PR } & Jan/90-dez/99 & 0,57 & 0,23 & 1,57 \\
\hline & Jan/90- jun/94 & 0,60 & & \\
\hline & Jul/94- dez/99 & 0,59 & & \\
\hline \multirow{3}{*}{ SP } & Jan/90-dez/99 & 0,90 & 0,17 & 1,54 \\
\hline & Jan/90- jun/94 & 0,92 & 0,20 & 1,73 \\
\hline & Jul/94- dez/99 & 0,93 & 0,16 & 1,49 \\
\hline \multirow{3}{*}{$M G$} & Jan/90-dez/99 & 0,40 & & \\
\hline & Jan/90- jun/94 & 0,33 & & \\
\hline & Jul/94- dez/99 & 0,32 & & \\
\hline \multirow{3}{*}{ GO } & Jan/90-dez/99 & 0,54 & & \\
\hline & Jan/90- jun/94 & 0,54 & & \\
\hline & Jul/94- dez/99 & 0,64 & & \\
\hline \multirow{3}{*}{ BA } & Jan/90-dez/99 & 0,84 & & \\
\hline & Jan/90- jun/94 & 0,87 & & \\
\hline & Jul/94- dez/99 & 0,83 & & \\
\hline
\end{tabular}

${ }^{40}$ Com a ocorrência de defasagem distribuída no ajustamento de preços, o valor da elasticidade de sua transmissão no instante em que ocorre a mudança na variável independente é apenas uma fração do efeito total que essa variação deverá causar sobre a variável dependente. Há, 
A Tabela 27 apresenta dados relativos à elasticidade de transmissão de preços pago aos produtores dos Estados que apresentaram causalidade unidirecional. Verifica-se que a transmissão contemporânea é a predominante e que somente entre os Estados da Bahia e Paraná ocorreu defasagem. O lógica econômica para explicar estas relações não foi determinada pelos motivos já abordados, ou seja, o desconhecimento da real quantidade ofertada mensalmente pelas regiões produtoras e do fluxos destas safras. Mas, estes resultados tem importância por indicaram que não há um Estado líder na formação do preço. Isto reforça a dedução de que as alterações de preços ocorrem noutro nível de mercado, que, conforme já ficou evidenciado, é o atacadista.

Tabela 27. Elasticidade de transmissão de preços pagos aos produtores dos principais estados produtores de feijão no Brasil, no período de 1990-99.

\begin{tabular}{|c|c|c|c|c|c|}
\hline \multicolumn{3}{|c|}{ Causalidade } & Contemporânea & Acumulada & Período-mês \\
\hline $\mathrm{BA}$ & $\Rightarrow$ & $\mathrm{PR}$ & $0,465^{* *}$ & $0,709^{\star \star}$ & 1 \\
\hline PR & $\Rightarrow$ & RS & $0,455^{*}$ & & 0 \\
\hline RS & $\Rightarrow$ & GO & $0,808^{*}$ & & 0 \\
\hline SP & $\Rightarrow$ & PR & $0,711^{* *}$ & & 0 \\
\hline SC & $\Rightarrow$ & RS & $0,472^{*}$ & & 0 \\
\hline RS & $\Rightarrow$ & MG & 0,757 & & 0 \\
\hline
\end{tabular}

Entre parênteses estão os valores da estatística t.

* significativo a $1 \%$

** significativo a $5 \%$

portanto, a necessidade de somar o efeito que a variação na variável exógena nos diversos períodos para se determinar o efeito total Aguiar (1990). 


\subsection{Estudo e projeção do Consumo}

Discutir consumo de feijão é complexo, em virtude das diferentes preferências por diversos tipos feijão comum e, ainda, pelo grande consumo de outros tipos de feijão no País, com destaque para o caupi. Estima-se que no Brasil o mercado consumidor deste tipo de feijão seja de 29 milhões de pessoas, concentradas principalmente nos Estados nordestinos.

Os dados do ENDEF-1974/75 (IBGE,1978) e POF-1987/88 (IBGE,1991), mostraram que, no período compreendido entre estas pesquisas, a taxa de crescimento do consumo per capita nas metrópoles foi negativa de 0,10 . Já com os valores da Tabela 3 , que considera o consumo total em todo País, verifica-se que o consumo per capita no mesmo período apresentou taxa de crescimento negativa de 0,17 . Comparando estes resultados conclui-se que, no período de 1974 a 1988, o decréscimo do consumo de feijão foi menor nas metrópoles do que a média geral no País.

A Figura 17 mostra o resultado encontrado para o consumo per capita na década de 90, ressaltando-se que é bastante semelhante ao da Tabela 3. A Figura 17 mostra, também, que em dois anos ocorreu um súbito aumento do consumo, mas, em ambos os casos, foram seguidos por um período de retração de consumo com tendência a um valor médio. Portanto, o consumo de feijão é instável de ano para ano. Aliás, conforme verifica-se na Tabela 3, este comportamento ocorreu em outros períodos. 


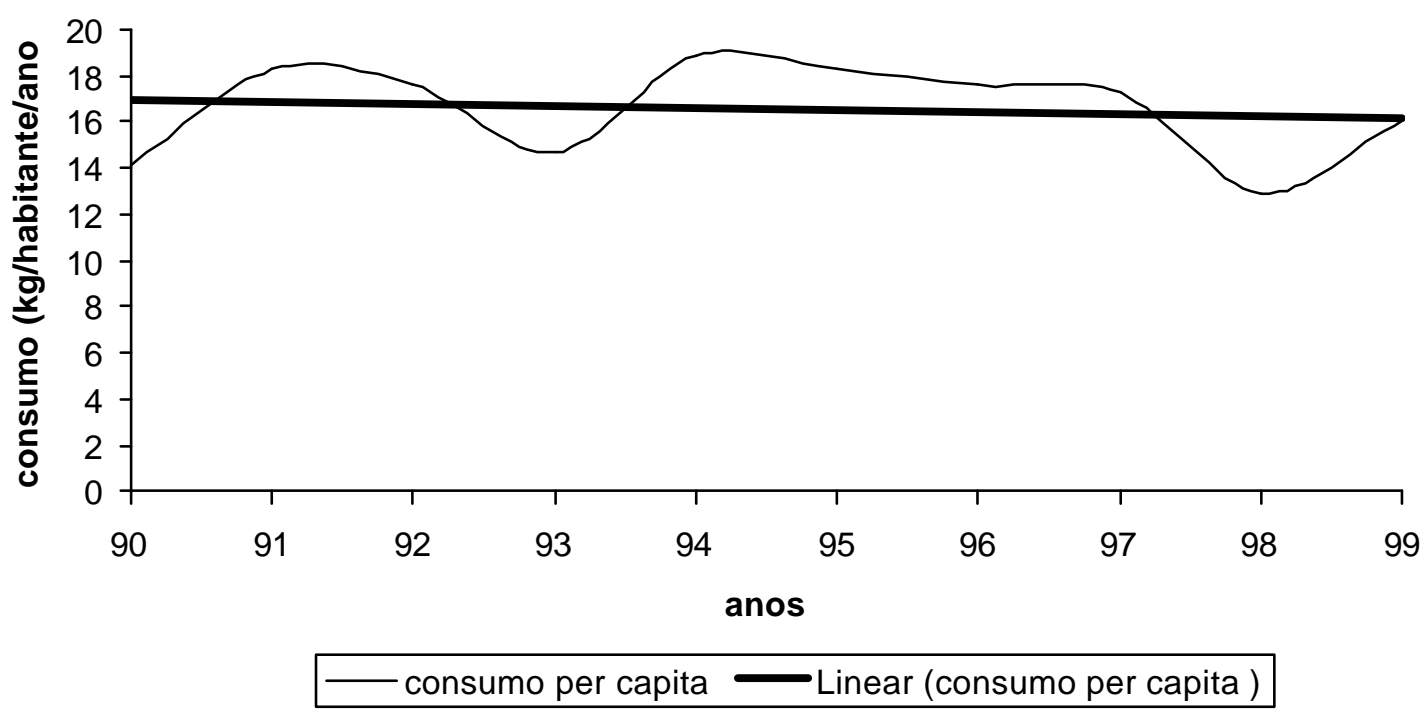

Figura 17 - Consumo per capita aparente anual de feijão no Brasil no período de 1990-99.

Fonte: Levantamento Sistemático da Produção Agrícola - IBGE (1990...), IBGE (1996), adaptado pelo autor.

Os valores da projeção encontrados pela expressão de Barros (1987), modificada com o fator de correção estão na Tabela 28. Foi calculada a elasticidade renda da demanda do feijão, utilizando a equação 3 , encontrandose o valor $-0,042$, semelhante ao de Hoffmann (1995). Nos quatro cenários considerando taxas de crescimento da renda per capita de $0 \%, 2 \%, 3 \%$ e $4 \%$, observa-se que o consumo decresceu, enquanto dentro de cada cenário as variações são pequenas, coerente com a magnitude e sinal da elasticidade bem 
como a tendência histórica de diminuição de consumo. Entretanto, não fica claro quando se esgotará este processo de redução de consumo. Para responder a esta questão, é necessário que os fatores que causam e influenciam este comportamento sejam melhor equacionados. Considerando que os padrões urbanos de consumo tendem a ser adotados pelas famílias residentes em áreas rurais (Hoffmann,1995), e levando em conta também os dados das pesquisas de orçamento familiares, pode-se inferir um indicativo, pois a POF-1995/96 (IBGE,1998) mostrou que em Belém, Belo Horizonte, São Paulo, Curitiba, Porto alegre e Goiânia, o consumo per capita está abaixo de 10 $\mathrm{kg} / \mathrm{habitante} / \mathrm{ano}$.

Tabela 28. Projeção da demanda de feijão no período de 2000 a $2005^{1}$.

\begin{tabular}{ccccc|cccc}
\hline \multirow{3}{*}{ Ano } & \multicolumn{3}{c|}{ Consumo total (1000 t) } & \multicolumn{4}{c}{$\begin{array}{c}\text { Consumo per capita } \\
\text { (kg/habitante) }\end{array}$} \\
\cline { 2 - 9 } & $0 \%^{2}$ & $2 \%^{2}$ & $3 \%^{2}$ & $4 \%^{2}$ & $0 \%$ & $2 \%^{2}$ & $3 \%^{2}$ & $4 \%^{2}$ \\
\hline 2000 & 2721,72 & 2606,26 & 2605,12 & 2603,98 & 16,40 & 15,71 & 15,70 & 15,69 \\
2001 & 2726,56 & 2525,65 & 2523,44 & 2521,23 & 16,24 & 15,04 & 15,03 & 15,02 \\
2002 & 2731,12 & 2447,54 & 2444,32 & 2441,10 & 16,07 & 14,40 & 14,39 & 14,37 \\
2003 & 2735,40 & 2371,84 & 2367,68 & 2363,53 & 15,91 & 13,79 & 13,77 & 13,74 \\
2004 & 2739,39 & 2298,48 & 2293,44 & 2288,42 & 15,74 & 13,21 & 13,18 & 13,15 \\
2005 & 2743,08 & 2227,39 & 2221,53 & 2215,69 & 15,58 & 12,65 & 12,61 & 12,58
\end{tabular}

1 = Para efeitos dos cálculos foi estimado que em cada ano ficam estocadas cerca de $300 \mathrm{mi} / \mathrm{t}$ que cerca de $8 \%$ da produção total é utilizado como semente (aproximadamente $187 \mathrm{mil} / \mathrm{t}$ ) e $3 \%$ são perdidas em armazenamento e transporte (aproximadamente $70 \mathrm{mil} / \mathrm{t}$ ). 2 = são cenários para taxa de crescimento da renda per capita 


\section{CONCLUSÕES}

Os resultados permitiram concluir que as mudanças políticas da década de 90 não alteraram o padrão da produção de feijão nos tradicionais Estados produtores. Ou seja, embora tenha ocorrido uma alternância de produção entre estes Estados e um incentivo de produção na região Nordeste, se mostraram elementos capazes de caracterizar uma clara tendência de ruptura de comportamento de produção. Quanto à comercialização, o que se observou foram ajustes devidos às mudanças de estratégias no mercado atacadista, ou seja, atitudes que mudaram o modo de atuação deste segmento e que, portanto, afetaram todos produtos de um modo geral e não especificamente o feijão.

Observou-se também que a produção está ajustada à demanda, ou seja, o produto não é ofertado em excesso porque não é armazenado por longo tempo. Quanto à quantidade importada, ocorreu um aumento, mas não se pode afirmar que tenha ocorrido em função das facilidades impostas pela abertura comercial, ou pela maior competitividade de produtos de outros países, pois somente o feijão preto responde aproximadamente $80 \%$ da importação, caracterizando-o como o tipo de feijão que consegue disputar mercado.

Existem microrregiões cujas produções são mais significativas e constantes, e quando são feitas projeções de comportamento de mercado baseando-se somente nos resultados dessas regiões, podem ocorrer falhas. Em outras palavras, as situações dessas microrregiões causam grandes 
impactos no comportamento mercado, mas o equilíbrio final depende da conjunção de resultados das demais regiões.

Em relação aos preços recebidos pelos produtores, a queda de cerca de 33\% não foi suficiente para desencorajar o produtor a produzir, pois, a produção total não sofreu alteração significativa. Os supermercados ganham importância na distribuição do feijão ao varejo e, apesar destas unidades de vendas terem reduzido o número de agentes no processo de comercialização, ocorreu um aumento na margem de comercialização entre o atacado e varejo, de $23 \%$ em valores absolutos e $53 \%$ em valores relativos. A justificativa advém da melhoria do produto final, visto que estas unidades vendem mercadorias embaladas e com marcas comerciais, provocando o estabelecimento de padrões mínimos de qualidade. Outros motivos são os novos serviços, prestados pelos varejistas, por exemplo, atendimento 24 horas, estacionamentos com segurança, etc.

A margem de comercialização relativa entre o atacado e produtor sofreu pequena redução, média de $2,7 \%$, significando que a margem de comercialização relativa entre estes níveis tendeu a se manter no mesmo patamar. Deste modo, concluiu-se que o dispêndio do consumidor entre estes níveis de mercado, praticamente se manteve constante. No Estado de São Paulo, porém, verificou-se aumento de $32 \%$ na margem de comercialização, associado a uma queda importante nos preços ao produtor. Em conseqüência, a produção estadual também caiu.

Os estudos econométricos mostram que existe co-integração entre os preços recebidos pelos produtores dos sete principais Estados produtores, bem como entre estes preços e os preços do mercado atacadista de São Paulo. Observou-se também que existe uma alta correlação contemporânea entre os preços recebidos pelos produtores nos Estados e entre 
estes e os preços dos mercados atacadista e varejista de São Paulo, indicando existir uma interação entre os níveis de mercado.

Poucas relações de causalidade foram encontradas entre os sete principais Estados produtores. Este resultado pode ser atribuído ao fato de que foram utilizados preços médios mensais e estes não captaram as instabilidades ocorridas durante os meses. Em outras palavras, o preço médio mensal não permite verificar a dinâmica de ajustamento, devido a indisponibilidade de dados. Os testes, por outro lado, mostraram que a causalidade predomina do atacado para os produtores e do atacado para o varejo.

Ainda, ficou confirmado o papel do setor intermediário de abrandar os choques, pois uma elevação de $10 \%$ nos preços ao atacado causa uma elevação de $7,4 \%$ no preço do varejo. No período após o Plano Real o impacto reduziu para $6,4 \%$. Em níveis do produtor e atacado, observou-se que a intensidade de transmissão de preços varia de Estado para Estado, mas, comparando os dois períodos estudados, antes e após o Plano Real, constatase que não houve alteração entre eles.

Nas quatro últimas décadas, observou-se uma tendência decrescente do consumo per capita de feijão da ordem de $1 \%$ ao ano. Esta tendência porém, não é linear, existindo oscilações entre os anos. A projeção para o período de 2000 a 2005 indica que, independente da taxa de crescimento da renda, a tendência é de redução do consumo per capita de feijão no Brasil, embora lenta, podendo-se inferir que esta leguminosa tem e ainda terá, por longo tempo, importância na alimentação do brasileiro. Quanto ao futuro, sugere-se que os atores dessa cadeia produtiva devam ficar atentos em acelerar as buscas de formas alternativas de apresentação do produto, mais adequadas às exigências dos consumidores. 
Trabalhos como este encontram algumas limitações de referenciais relacionados com a pouca disponibilidade de dados e escassez de outros trabalhos na área. A maior restrição foi a dificuldade de dimensionar 0 tamanho real da produção e consumo de feijão no Brasil, pois, nas regiões onde há concentração da produção, ocorre o fenômeno denominado de autoconsumo, ou seja, na média, tem-se estimado que $40 \%$ da produção de feijão não são comercializadas.

Este estudo suscita algumas indagações que são de fundamental importância para melhor compreensão do mercado de feijão. Por exemplo, detalhar a seqüência das safras nas regiões produtoras, conhecer como as regiões produtoras se relacionam, o poder de cada uma na formação do preço, e sobretudo criar um mecanismo capaz de monitorar os acontecimentos nestas regiões. Estas informações são subsídios essenciais para se desenvolver um modelo matemático capaz de fornecer informações confiáveis sobre a quantidade de produto que será ofertado em curtos espaços de tempo, semanal ou no máximo quinzenal. Desta forma certamente reduzirá o espaço para especulações no mercado. Portanto, muitos questionamentos ainda pairam sobre o cenário de produção e comercialização do feijão no Brasil, corroborando com a demanda de mais estudos sobre este produto. 


\section{REFERÊNCIAS BIBLIOGRÁFICAS}

AGUIAR, D. R.D. Formação de preço na indústria brasileira de soja: 19821989. Piracicaba, 1990. 140p. Dissertação (Mestrado) - Escola Superior de Agricultura "Luiz de Queiroz", Universidade de São Paulo.

AGUIAR, D. R.D. Custo, risco e margem de comercialização de arroz e de feijão no Estado de São Paulo: análise dinâmica e teste de modelos alternativos. Piracicaba, 1994. 185p. Tese (Doutorado) - Escola Superior de Agricultura "Luiz de Queiroz", Universidade de São Paulo.

AGUIAR, D. R.D. ; BARROS, G.S.A.C. ; BURNQUIST, H.L. ; FERREIRA, L.R. Análise da eficiência e competitividade no sistema de comercialização do feijão. Revista de Economia Rural, v.32, n.2, p.145-158, abr./jun.1994.

ALVES, J.M. Transmissão de preços e margens de comercialização de abacaxi, banana e laranja em Minas Gerais. Viçosa, 1996. 74p. Dissertação (Mestrado) - Universidade Federal de Viçosa.

ANEFALOS, L.C. ; CAIXETA FILHO, J.V. Tecnologia de informação e sua influência sobre os rumos da comercialização de produtos. Informações econômicas, v.28, n.6, p.45-53, jun.1998.

BAHIA, L.D. Grau de monopólio e testes de Granger: causalidade entre custos e preços na indústria brasileira (1978 - 1998). Brasília : Instituto de Pesquisa Econômica Aplicada - IPEA, 2000. (Textos para Discussão, n.170) 
BARROS, G.S.A.C. Economia da comercialização agrícola. http://cepea.esalq.usp.br/publicações. (25/abril/2000)

BARROS, G.S.A.C. Economia da comercialização agrícola. Piracicaba: FEALQ, 1987. 306p.

BARROS, G.S.A.C. Transmissão de preços pela central de abastecimento de São Paulo, Brasil. Revista Brasileira de Economia, v.44, n.1, p.5-20, jan./mar.1990.

BARROS, G.S.A.C. ; MARTINES FILHO, J.G. Transmissão de preços e margens de comercialização de produtos agrícolas. In: DELGADO, G.C.; GASQUES, J.G., VERDE, C.M.V. (Org.) Agricultura e políticas públicas. Brasília: Instituto de Pesquisa Econômica Aplicada, 1990. cap.8, p.515-565.

BLISKA, F.M.M. Transmissão de preços de carne bovina entre níveis de mercado: uma aplicação do modelo de auto-regressão vetorial. Piracicaba, 1989. 209p. Dissertação (Mestrado) - Escola Superior de Agricultura "Luiz de Queiroz", Universidade de São Paulo.

BRASIL. Ministério da Agricultura, do Abastecimento e da Reforma Agrária. Companhia Nacional de Abastecimento. Previsão e acompanhamento de safras, 1991-1998.

BURNQUIST, H. L. Questão da causalidade entre preços a diferentes níveis de mercados agrícolas. Piracicaba, 1986. 83p. Dissertação (Mestrado) - Escola Superior de Agricultura “Luiz de Queiroz”, Universidade de São Paulo.

CENTRO DE ESTUDOS AVANÇADOS EM ECONOMIA APLICADA. Oligopolização no setor industrial lácteo no Brasil. Piracicaba: ESALQ, 1999. 152p. (Relatório Final) 
COMISSÃO DE FINANCIAMENTO DA PRODUÇÃO. Estudo do consumo de alimentos básicos no Brasil: feijão. Brasília: CFP, 1981. 87p.

DEPARTAMENTO INTERSINDICAL DE ESTATÍSTICA E ESTUDOS SÓCIOECONÔMICOS. Boletim Dieese. São Paulo: DIEESE, 1990-1999.

DICKEY, D.A. ; FULLER. W.A. Likelihood ratio statistics for auto-regressive time series with a unit root. Econometrica, v.49, n.4, p.1057-72, 1981.

DOAN, T.A. ; LITTERMAN, R.B. User's manual: Rats. Minneapolis: Var Econometris, 1987.

ENDERS, W. Applied econometric time series. New York: John Wiley \& Sons, 1995. p.257

ENGLE, R.F. ; YOO, S. Forecasting an testing in coitegrated systems. Journal of econometrics, v.35, n.1, p.143, 1987.

FERREIRA, C.M. ; YOKOYAMA, L. P. Comportamento dos consumidores de feijão. In: REUNIÃO NACIONAL DE PESQUISA DE FEIJÃO, 6., Salvador, 1999. Resumos. Santo Antônio de Goiás: Embrapa Arroz e Feijão, 1999. p.717- 719.

FERREIRA, C.M. Competitividade da cadeia agroalimentar do feijão de cores, da Região de Itaberaí-GO. In: Cadeias produtivas no Brasil. Brasília, 2001. /No prelo/

GARDNER, B.L. The farm-retail price spread in a competitive food industry. American Journal of Agricultural Economics, v.57, n.3, p.399-409, 1975.

GRANGER, C. ; NEWBOLD, P. Spurious regressions in econometrics. Journal of Econometrics, v.2, n.2, p.111-120, July 1974. 
GUIMARÃES, V.A. Comercialização e transmissão de preços de carne de frango no Estado de São Paulo. Piracicaba, 1990. 119p. Dissertação (Mestrado) Escola Superior de Agricultura "Luiz de Queiroz", Universidade de São Paulo.

GUJARATI, D.N. Basic econometrics. 3.ed. Singapore: McGraw-Hill,Inc., 1995. 838p.

HEIEN, D.M. Markup pricing in a dynamic model of food industry. Americam Journal of Agricultural Economics, v.62, p.10-18, 1980.

HOFFMANN, R. A diminuição do consumo de feijão no Brasil. Estudos econômicos, v.25, n.2, p.189-201, maio/ago.1995.

ÍNDICE Geral de Preços. Suma econômica, n.262, fev. 2000.

INFORMAÇÕES ECONOMICAS. São Paulo: Instituto de Economia Agrícola, 1990 - 1999.

INFORMATIVO BOLSA DE MERCADORIAS DO ESTADO DE GOIÁS. Goiânia: BMGO, 1994-1999.

INSTITUTO BRASILEIRO DE GEOGRAFIA E ESTATÍSTICA. Estudo nacional da despesa familiar - ENDEF: consumo alimentar - despesas das famílias. Rio de Janeiro: FIBGE, 1978.

INSTITUTO BRASILEIRO DE GEOGRAFIA E ESTATÍSTICA. Anuário estatístico do Brasil. Rio de Janeiro: FIBGE, 1996. v.56, p.2-14.

INSTITUTO BRASILEIRO DE GEOGRAFIA E ESTATÍSTICA. Pesquisa de orçamentos familiares 1987-1988. Rio de Janeiro: FIBGE, 1991. 
INSTITUTO BRASILEIRO DE GEOGRAFIA E ESTATÍSTICA. Pesquisa de orçamentos familiares 1995-1997. Rio de Janeiro: FIBGE, 1998.

INSTITUTO BRASILEIRO DE GEOGRAFIA E ESTATístICA. Produção agrícola municipal: culturas temporárias e permanentes. (disquetes). Rio de Janeiro: FIBGE, 1990-1996.

JUNQUEIRA, P.C. ; LINS, E.R. ; AMARO, A. A comercialização de produtos agrícolas no estado de São Paulo. Agricultura em São Paulo, v.15, n.1/2, p.13-32, 1968.

JUNQUEIRA, P.C. ; CANCEGLIERO, L.F.B. ; MATSUNAGA, M. ; YAMAGUISHI, C.T. Aspectos econômicos da produção e comercialização do feijão, 1971. Boletim técnico do Instituto de Economia Agrícola, v.17, n.7/8, jul./ago.1971.

LEVANTAMENTO SISTEMÁTICO DA PRODUÇÃO AGRÍCOLA. Rio de Janeiro: IGBE, 1990-1999.

MAIA, S.F. Elasticidade de transmissão de preços do trigo: um enfoque econométrico. Economia em revista, v.4, n.1, p.27-33, 1996.

MARTINS, E. Variações no consumo de alimentos no Brasil de 1974/75 a 1987/88. Piracicaba, 1998. 117p. Dissertação (Mestrado) - Escola Superior de Agricultura "Luiz de Queiroz". Universidade de São Paulo.

PARANÁ. Secretaria de Agricultura e Abastecimento. Departamento de Economia Rural. Acompanhamento da situação agropecuária do Paraná. Curitiba, 1990-1999.

PREÇOS AGRÍCOLAS. Piracicaba: USP.ESALQ/CEPEA, 1997-1999. 
ROESSING, A. C. ; YOKOYAMA, L.P. ; FERREIRA, C.M. ; SÁ, J.M. Oferta e demanda de arroz e feijão no Brasil: período 1980-1994. Londrina. Embrapa, 1998. 21p.

SANTIAGO, M.M.D. ; PINO, F.A. ; BUENO, C.A .F. ; FRANCISCO, U.L.F.S. ; OLIVEIRA, J. E. ; SPERS, E.E. ; NASSAR, A.M. Mercado atacadista de produtos agrícolas: pesquisa piloto na cidade de São Paulo. Informações econômicas, v.30, p.33-52, 2000.

SILVA, J.G. A nova dinâmica da agricultura brasileira. Campinas: UNICAMP.IE, 1996. 217p.

SPERS, E. E. ; NASSAR, A.M. Competitividade do sistema agroindustrial do feijão. In: Competitividade do agribusiness brasileiro. São Paulo: USP.IPEA.PENSA, 1998. v.1.

STONE, L.F. ; SARTORATO, A. O cultivo do feijão: recomendações técnicas. Brasília: EMBRAPA. Centro Nacional de Pesquisa de Arroz e Feijão, 1994. 83p.

TSUNICHIRO, A. ; GUSMÃO, A.S.L. ; BULISANI, E.A. ; CASTRO, J.L. ; SAVITCI, L.A. ; SARTORI, R.M. Repensando a agricultura paulista: cadeia produtiva do feijão. São Paulo: Secretaria de Agricultura e Abastecimento do Estado de São Paulo, 1996. 38p.

VIEIRA, R.C.M.T. (Coord.). Avaliação global do setor agrícola: grãos no Brasil. Brasília: IPEA, 1994. 119p. (Estudos de Política Agrícola. Documentos de Trabalho, 15). 1994. 


\section{APÊNDICES}


Tabela 1A. Valores críticos das estatísticas $\tau_{\tau}, \tau_{\beta \tau}, \tau_{\mu}, \tau_{\alpha \tau}$ e $\tau$ para raiz unitária $\mathrm{e}$ estatísticas.

\begin{tabular}{ccc}
\hline $\begin{array}{c}\text { Tamanho da } \\
\text { amostra }(\mathrm{n})\end{array}$ & 1 & Probabilidade (\%) \\
\hline \multicolumn{3}{c}{$\tau_{\tau}$ (testa estacionariedade em modelo com constante e tendência) } \\
100 & -4.04 & -3.45 \\
250 & $-3,99$ & -3.43 \\
\hline \multicolumn{3}{c}{$\tau_{\beta \tau}$ (testa significância do termo de tendência determinística no } \\
100 & modelo) & 2.79 \\
250 & 3.53 & 2.79 \\
\hline \multicolumn{3}{c}{$\tau_{\mu}$ (testa estacionariedade em modelo com constante) } \\
100 & -3.51 & -2.59 \\
250 & -3.46 & $-2,83$ \\
\hline \multicolumn{3}{c}{$\tau_{\alpha \mu}$ (testa significância da constante no modelo) } \\
100 & 3.22 & 3.53 \\
250 & 3,19 & 3.54 \\
\hline \multicolumn{3}{c}{$\tau$} \\
100 & tendência) & -1.95 \\
250 & -2.60 & -1.95 \\
\hline
\end{tabular}

Fonte: Dickey e Fuller (1981)

Tabela 2A. Distribuição empírica de $\left(\Phi_{3}\right)$ e $\left(\Phi_{1}\right)$.

\begin{tabular}{ccc}
\hline $\begin{array}{c}\text { Tamanho da } \\
\text { amostra }(\mathrm{n})\end{array}$ & 1 & Probabilidade \\
\hline \multicolumn{3}{c}{$\left(\Phi_{3}\right)$ testa a hipótese $(\partial)=(\beta)=0$} \\
200 & 8,73 & \\
250 & 8,43 & 6,49 \\
100 & $\left(\Phi_{1}\right)$ testa a hipótese $(\alpha)=(\partial)=0$ \\
250 & 6,70 & 6,34 \\
\hline
\end{tabular}

Fonte:Dickey e Fuller (1981) 
Tabela 3A. Valores críticos do teste de co-integração. -

\begin{tabular}{c|c|c|c|c}
\hline \multirow{2}{*}{$\begin{array}{c}\text { No de } \\
\text { variáveis }\end{array}$} & Tamanho da & \multicolumn{3}{|c}{ Nível de significância } \\
\cline { 3 - 5 } & amostra & $1 \%$ & $5 \%$ & $10 \%$ \\
\hline \multirow{2}{*}{$1^{\mathrm{a}}$} & 50 & 2,62 & 1,95 & 1,61 \\
& 100 & 2,60 & 1,95 & 1,61 \\
& 250 & 2,58 & 1,95 & 1,62 \\
& 500 & 2,58 & 1,95 & 1,62 \\
\hline \multirow{3}{*}{$1^{\mathrm{b}}$} & 50 & 3,58 & 2,93 & 2,60 \\
& 100 & 3,51 & 2,89 & 2,58 \\
& 250 & 3,46 & 2,88 & 2,57 \\
& 500 & 3,44 & 2,87 & 2,57 \\
\hline \multirow{3}{*}{2} & 50 & 4,32 & 3,67 & 3,28 \\
& 100 & 4,07 & 3,37 & 3,03 \\
& 200 & 4,00 & 3,37 & 3,02 \\
\hline \multirow{3}{*}{3} & 50 & 4,84 & 4,11 & 3,73 \\
& 100 & 4,45 & 3,93 & 3,59 \\
& 200 & 4,35 & 3,78 & 3,47 \\
\hline \multirow{3}{*}{4} & 50 & 4,94 & 4,35 & 4,02 \\
& 100 & 4,75 & 4,22 & 3,89 \\
& 200 & 4,70 & 4,18 & 3,89 \\
\hline \multirow{2}{*}{5} & 50 & 5,41 & 4,76 & 4,42 \\
& 100 & 5,18 & 4,58 & 4,26 \\
& 200 & 5,02 & 4,48 & 4,18 \\
\hline
\end{tabular}

Fonte: Engle e Yoo (1987).

$\mathrm{a}=$ valores de $(\tau)$, de Fuller.

$\mathrm{b}=$ valores de $\left(\tau_{\mu}\right)$,de Fuller. 
Tabela 4A. Relação das variáveis utilizadas no trabalho.

\begin{tabular}{cc}
\hline Variável & \multicolumn{1}{c}{ Identificação } \\
\hline Precrs & Preço médio mensal recebido pelos produtores do estado do Rio Grande do Sul - saco $60 \mathrm{~kg}$ de feijão \\
Precsp & Preço médio mensal recebido pelos produtores do estado de São Paulo \\
Precpr & Preço médio mensal recebido pelos produtores do estado do Paraná - saco $60 \mathrm{~kg}$ de feijão \\
Precsc & Preço médio mensal recebido pelos produtores do estado de Santa Catarina - saco $60 \mathrm{~kg}$ de feijão \\
Precmg & Preço médio mensal recebido pelos produtores do estado de Minas Gerais - saco 60 kg de feijão \\
Precgo & Preço médio mensal recebido pelos produtores do estado de Goiás - saco $60 \mathrm{~kg}$ de feijão \\
Precba & Preço médio mensal recebido pelos produtores do estado da Bahia - saco $60 \mathrm{~kg}$ de feijão \\
Preata & Preço médio mensal no mercado atacadista de São Paulo - saco $60 \mathrm{~kg}$ de feijão \\
Prevar & Preço médio mensal no mercado atacadista de São Paulo - saco $60 \mathrm{~kg}$ de feijão \\
Salmin & Valor do salário mínimo \\
\hline Preole & Preço médio mensal do litro de óleo diesel
\end{tabular}

Tabela 5A. Resultados dos testes Akaike e Schwarz.

\begin{tabular}{ccc}
\hline Variável & Akaike & Schuwarz \\
\hline Precrs & 8 & 7 \\
Precsp & 11 & 4 \\
Precpr & 11 & 4 \\
Precsc & 12 & 1 \\
Precmg & 11 & 4 \\
Precgo & 12 & 2 \\
Precba & 11 & 1 \\
Preata & 11 & 4 \\
Prevar & 11 & 4 \\
Salmin & 5 & 5 \\
Preole & 8 & 4 \\
\hline
\end{tabular}


Tabela 6A. Resultados do teste de raiz unitária - regressão com constante e tendência, em nível.

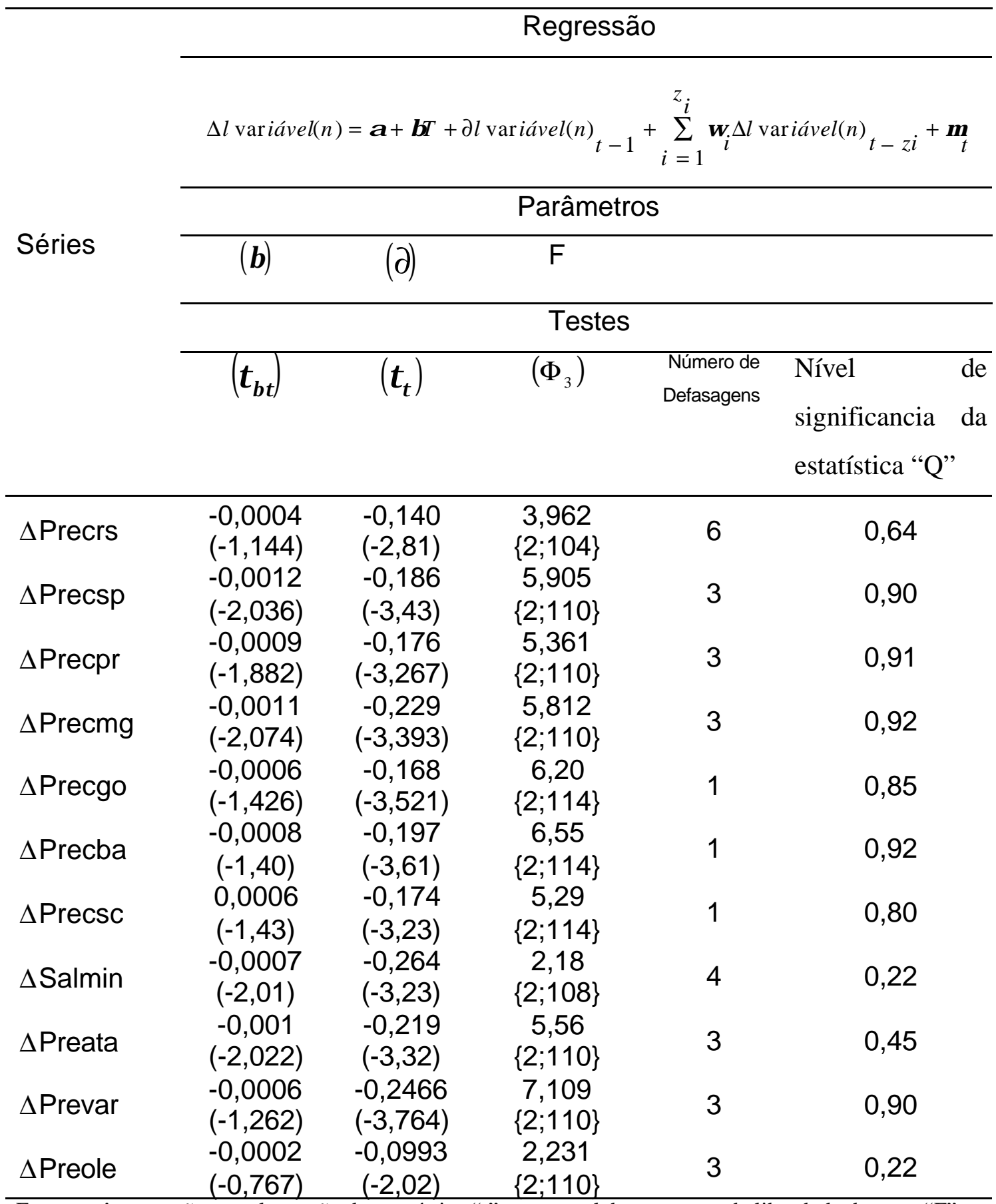


Tabela 7A. Resultados do teste de raiz unitária - regressão com constante, em nível.

\begin{tabular}{|c|c|c|c|c|c|}
\hline \multirow{6}{*}{ Séries } & \multicolumn{5}{|c|}{ Regressão } \\
\hline & \multicolumn{5}{|c|}{$\Delta l$ variável $(n)=\alpha+\partial l$ variável $(n)_{t-1}+\sum_{i=1}^{\iota} \omega_{i} \Delta l$ variável $(n)_{t-z i}+\mu_{t}$} \\
\hline & \multicolumn{5}{|c|}{ Parâmetros } \\
\hline & \multicolumn{5}{|c|}{$F$} \\
\hline & \multicolumn{5}{|c|}{ Testes } \\
\hline & $\left(\tau_{\alpha \mu}\right)$ & $\left(\tau_{\mu}\right)$ & $\left(\Phi_{1}\right)$ & $\begin{array}{l}\text { Número de } \\
\text { Defasagens }\end{array}$ & $\begin{array}{c}\text { Nível de } \\
\text { significancia da } \\
\text { estatística "Q" }\end{array}$ \\
\hline$\Delta$ Precrs & $\begin{array}{l}0,454 \\
(2,51)\end{array}$ & $\begin{array}{l}-0,115 \\
(-2,56)\end{array}$ & $\begin{array}{c}\{2,105\} \\
(3,64)\end{array}$ & 6 & 0,76 \\
\hline$\Delta$ Precsp & $\begin{array}{l}0,523 \\
(2,70)\end{array}$ & $\begin{array}{l}-0,125 \\
(-2,72)\end{array}$ & $\begin{array}{c}\{2,111\} \\
(3,74)\end{array}$ & 3 & 0,92 \\
\hline$\Delta$ Precpr & $\begin{array}{l}0,489 \\
(2,63)\end{array}$ & $\begin{array}{l}-0,123 \\
(-2,64)\end{array}$ & $\begin{array}{c}\{2,111\} \\
(3,51)\end{array}$ & 3 & 0,94 \\
\hline$\Delta$ Precmg & $\begin{array}{l}0,646 \\
(2,63)\end{array}$ & $\begin{array}{l}-0,155 \\
(-2,66)\end{array}$ & $\begin{array}{c}\{2,111\} \\
(3,61)\end{array}$ & 3 & 0.96 \\
\hline$\Delta$ Precgo & $\begin{array}{c}0,570 \\
(-1,42)\end{array}$ & $\begin{array}{l}-0,139 \\
(-2,66)\end{array}$ & $\begin{array}{c}\{2,111\} \\
(5,24)\end{array}$ & 1 & 0.89 \\
\hline$\Delta$ Precba & $\begin{array}{l}0,680 \\
(3,27)\end{array}$ & $\begin{array}{l}-0,166 \\
(-3,52)\end{array}$ & $\begin{array}{c}\{2,111\} \\
(5,57)\end{array}$ & 1 & 0,94 \\
\hline$\Delta$ Precsc & $\begin{array}{l}0,521 \\
(2,86)\end{array}$ & $\begin{array}{l}-0,134 \\
(-3,23)\end{array}$ & $\begin{array}{c}\{2,111\} \\
(4,32)\end{array}$ & 1 & 0,91 \\
\hline$\Delta$ Salmin & $\begin{array}{l}0,901 \\
(2,51)\end{array}$ & $\begin{array}{l}-0,177 \\
(-2,52)\end{array}$ & $\begin{array}{c}\{2,104\} \\
(3,20)\end{array}$ & 4 & 0,33 \\
\hline$\Delta$ Preata & $\begin{array}{l}-0,647 \\
(2,59)\end{array}$ & $\begin{array}{l}0,147 \\
(2,61)\end{array}$ & $\begin{array}{l}\{2,111\} \\
(3,44)\end{array}$ & 3 & 0,52 \\
\hline$\Delta$ Prevar & $\begin{array}{l}1,014 \\
(3,12)\end{array}$ & $\begin{array}{l}-0,211 \\
(-3,13)\end{array}$ & $\begin{array}{c}\{2,104\} \\
(4,90)\end{array}$ & 3 & 0,93 \\
\hline$\Delta$ Preole & $\begin{array}{l}-0,037 \\
(-1,93)\end{array}$ & $\begin{array}{r}-0,076 \\
(-1,97) \\
\end{array}$ & $\begin{array}{c}\{2,111\} \\
(2,02) \\
\end{array}$ & 3 & 0,72 \\
\hline
\end{tabular}


Tabela 8A. Resultados do teste de raiz unitária - regressão sem constante e tendência, em nível.

\begin{tabular}{|c|c|c|c|}
\hline \multirow{6}{*}{ Séries } & \multicolumn{3}{|c|}{ Regressão } \\
\hline & \multicolumn{3}{|c|}{$\Delta l$ variável $(n)=\partial l$ variável $(n)_{t-1}+\sum_{i=1}^{z_{i}} \omega_{i} \Delta l$ variável $(n)_{t-z i}+\mu_{t}$} \\
\hline & \multicolumn{3}{|c|}{ Parâmetros } \\
\hline & \multicolumn{3}{|l|}{$(\rho)$} \\
\hline & \multicolumn{3}{|c|}{ Testes } \\
\hline & $\left(\tau_{\alpha \mu}\right)$ & $\begin{array}{l}\text { Número de } \\
\text { Defasagens }\end{array}$ & $\begin{array}{c}\text { Nível de } \\
\text { significancia da } \\
\text { estatística "Q" }\end{array}$ \\
\hline$\Delta$ Precrs & $\begin{array}{l}-0,002 \\
(-0,95)\end{array}$ & 6 & 0,64 \\
\hline$\Delta$ Precsp & $\begin{array}{l}-0,001 \\
(-0,41)\end{array}$ & 3 & 0,77 \\
\hline$\Delta$ Precpr & $\begin{array}{l}-0009 \\
(-0,24)\end{array}$ & 3 & 0,83 \\
\hline$\Delta$ Precmg & $\begin{array}{l}-0,002 \\
-0,51\end{array}$ & 3 & 0,87 \\
\hline$\Delta$ Precgo & $\begin{array}{l}-0,002 \\
(-0,60)\end{array}$ & 1 & 0,80 \\
\hline$\Delta$ Precba & $\begin{array}{l}-0,002 \\
(-0,60)\end{array}$ & 1 & 0,77 \\
\hline$\Delta$ Precsc & $\begin{array}{l}-0,002 \\
(-0,62)\end{array}$ & 1 & 0,81 \\
\hline$\Delta$ Salmin & $\begin{array}{l}-0,0005 \\
(-0,238)\end{array}$ & 4 & 0,27 \\
\hline$\Delta$ Preata & $\begin{array}{l}-0,0018 \\
(-0,418)\end{array}$ & 3 & 0,41 \\
\hline$\Delta$ Preole & $\begin{array}{c}-0,09 \\
(-0,54) \\
\end{array}$ & 3 & 0,71 \\
\hline
\end{tabular}


Tabela 9A. Resultados do teste de raiz unitária - regressão com constante e tendência, com uma defasagem.

\begin{tabular}{|c|c|c|c|c|c|}
\hline \multirow{6}{*}{ Séries } & \multicolumn{5}{|c|}{ Regressão } \\
\hline & \multicolumn{5}{|c|}{$\Delta \Delta l$ variável $(n)=\alpha+\beta T+\partial \Delta l$ variável $(n)_{t-1}+\sum_{i=1}^{z_{i}} \omega_{i} \Delta \Delta l$ variável $(n)_{t-z i}+\mu_{t}$} \\
\hline & \multicolumn{5}{|c|}{ Parâmetros } \\
\hline & \multicolumn{5}{|c|}{$\mathrm{F}$} \\
\hline & \multicolumn{5}{|c|}{ Testes } \\
\hline & $\left(\tau_{\beta \tau}\right)$ & $\left(\tau_{\tau}\right)$ & $\left(\Phi_{3}\right)$ & $\begin{array}{l}\text { Número de } \\
\text { Defasagens }\end{array}$ & $\begin{array}{c}\text { Nível de } \\
\text { significancia } \\
\text { da estatística } \\
\text { "Q" }\end{array}$ \\
\hline$\Delta \Delta$ Precrs & $\begin{array}{c}-0,00003 \\
(-0,093)\end{array}$ & $\begin{array}{c}-1,02 \\
(-4,044)\end{array}$ & $\begin{array}{c}8,294 \\
\{2,105\}\end{array}$ & 5 & 0,64 \\
\hline$\Delta \Delta$ Precsp & $\begin{array}{r}-0,00007 \\
(-0,143)\end{array}$ & $\begin{array}{l}-0,977 \\
(-6,44)\end{array}$ & $\begin{array}{c}20,82 \\
\{2,111\}\end{array}$ & 3 & 0,77 \\
\hline$\Delta \Delta$ Precpr & $\begin{array}{l}-0,0009 \\
(-0,205)\end{array}$ & $\begin{array}{c}-1,031 \\
(-6,405)\end{array}$ & $\begin{array}{c}20,56 \\
\{2,111\}\end{array}$ & 3 & 0,83 \\
\hline$\Delta \Delta$ Precmg & $\begin{array}{l}-0,0001 \\
(-0,31)\end{array}$ & $\begin{array}{l}-1,200 \\
(-6,92)\end{array}$ & $\begin{array}{l}24,00 \\
\{2,111\}\end{array}$ & 1 & 0,87 \\
\hline$\Delta \Delta$ Precgo & $\begin{array}{l}-0,00003 \\
(-0,08)\end{array}$ & $\begin{array}{l}-1,006 \\
(-8,29)\end{array}$ & $\begin{array}{l}34,42 \\
\{2,113\}\end{array}$ & 2 & 0,85 \\
\hline$\Delta \Delta$ Precba & $\begin{array}{l}-0,0001 \\
(-0,020)\end{array}$ & $\begin{array}{c}-1,066 \\
(-8,216)\end{array}$ & $\begin{array}{c}33,75 \\
\{2,113\}\end{array}$ & 1 & 0,87 \\
\hline$\Delta \Delta$ Precsc & $\begin{array}{l}0,0001 \\
(-0,32)\end{array}$ & $\begin{array}{l}-1,245 \\
(-9,28)\end{array}$ & $\begin{array}{c}43,09 \\
\{2,113\}\end{array}$ & 1 & 0,91 \\
\hline$\Delta \Delta$ Salmin & $\begin{array}{l}-0,0001 \\
(-0,341)\end{array}$ & $\begin{array}{c}-1,543 \\
(-6,137)\end{array}$ & $\begin{array}{c}19,27 \\
\{2,109\}\end{array}$ & 3 & 026 \\
\hline$\Delta \Delta$ Preata & $\begin{array}{l}-0,0001 \\
(-0,26)\end{array}$ & $\begin{array}{l}-1,224 \\
(-7,21)\end{array}$ & $\begin{array}{c}26,15 \\
\{2,111\}\end{array}$ & 2 & 0,41 \\
\hline$\Delta \Delta$ Preole & $\begin{array}{c}-0,0001 \\
(0,58)\end{array}$ & $\begin{array}{c}-1,543 \\
(-6,137)\end{array}$ & $\begin{array}{c}19,27 \\
\{2,109\}\end{array}$ & 2 & 0,72 \\
\hline
\end{tabular}

Entre parênteses são os valores são da estatística " $t$ " e entre colchetes o grau de liberdade do teste "F" 
Tabela 10A. Resultados do teste de raiz unitária.

\begin{tabular}{c|c|}
\hline Variável & Ordem de integração \\
\hline Precrs & $\mathrm{I}(1)$ \\
Precsp & $\mathrm{I}(1)$ \\
Precpr & $\mathrm{I}(1)$ \\
Precsc & $\mathrm{I}(1)$ \\
Precmg & $\mathrm{I}(1)$ \\
Precgo & $\mathrm{I}(1)$ \\
Precba & $\mathrm{I}(1)$ \\
Preata & $\mathrm{I}(1)$ \\
Prevar & $\mathrm{I}(0)$ \\
Salmin & $\mathrm{I}(1)$ \\
Preole & $\mathrm{I}(1)$ \\
\hline
\end{tabular}


Tabela 11A. Resultados do teste de co-integração.

\begin{tabular}{|c|c|c|c|}
\hline \multicolumn{2}{|c|}{ Séries } & Parâmetros & Teste DF \\
\hline Precsp & Precrs & $-0,17$ & $-3,29$ \\
\hline Precsp & Precsc & $-0,21$ & $-3,68$ \\
\hline Precsp & Precpr & $-0,44$ & $-5,02$ \\
\hline Precsp & Precmg & $-0,44$ & $-5,48$ \\
\hline Precsp & Precgo & $-0,35$ & $-4,04$ \\
\hline Precsp & Precba & $-0,64$ & $-6,15$ \\
\hline Precrs & Precsc & $-0,40$ & $-4,58$ \\
\hline Precrs & Precpr & $-0,17$ & $-2,99$ \\
\hline Precrs & Precmg & $-0,30$ & $-4,16$ \\
\hline Precrs & Precgo & $-0,17$ & $-3,42$ \\
\hline Precrs & Precba & $-0,22$ & $-3,66$ \\
\hline Precsc & Precpr & $-0,21$ & $-3,68$ \\
\hline Precsc & Precmg & $-1,36$ & $-9,44$ \\
\hline Precsc & Precgo & $-1,19$ & $-8,69$ \\
\hline Precsc & Precba & $-1,39$ & $-9,92$ \\
\hline Precpr & Precmg & $-0,59$ & $-5,97$ \\
\hline Precpr & Precgo & $-0,37$ & $-4,59$ \\
\hline Precpr & Precba & $-0,62$ & $-6,06$ \\
\hline Precmg & Precgo & $-0,51$ & $-5,93$ \\
\hline Precmg & Precba & $-0,54$ & $-5,69$ \\
\hline Precgo & Precba & $-0,58$ & $-5,80$ \\
\hline Preata & Precsp & $-0,41$ & $-4,73$ \\
\hline Preata & Precrs & $-0,24$ & $-3,69$ \\
\hline Preata & Precsc & $-0,28$ & $-4,13$ \\
\hline Preata & Precpr & $-0,55$ & $-5,68$ \\
\hline Preata & Precmg & $-0,63$ & $-6,32$ \\
\hline Preata & Precgo & $-0,34$ & $-3,65$ \\
\hline Preata & Precba & $-0,43$ & $-4,61$ \\
\hline Prevar & Precsp & $-0,12$ & $-2,44$ \\
\hline Prevar & Precrs & $-0,20$ & $-3,43$ \\
\hline Prevar & Precsc & $-0,22$ & $-3,65$ \\
\hline Prevar & Precpr & $-0,16$ & $-2,36$ \\
\hline Prevar & Precmg & $-0,34$ & $-3,06$ \\
\hline Prevar & Precgo & $-0,19$ & $-2,56$ \\
\hline Prevar & Precba & $-0,23$ & $-2,91$ \\
\hline Prevar & Preata & $-0,16$ & $-1,99$ \\
\hline
\end{tabular}


Tabela 12A. Resultados do teste de correlação.

\begin{tabular}{|c|c|c|}
\hline Séries & Ordem & Resultados \\
\hline \multirow{3}{*}{ dlprecsp dlprecrs } & $0-4$ & $0.5190425^{*} 0.0085556-0.234286^{*} 0.039750 .2257644^{*}$ \\
\hline & $5-8$ & $-0.1231952-0.09506800 .0492297-0.0650002$ \\
\hline & & \\
\hline \multirow{3}{*}{ dlprecrs dlprecsp } & $0-4$ & $0.5190425^{*} 0.0847534-0.0629170 .06574570 .0380331$ \\
\hline & $5-8$ & $-0.2264992^{*}-0.00926800 .0851836-0.0103500$ \\
\hline & $9-12$ & $0.0132428-0.0558664-0.0237098-0.0710578$ \\
\hline \multirow[b]{2}{*}{ dlprecsp dlprecsc } & $0-4$ & $0.6077152^{*} 0.1397560-0.1399160 .05191660 .1126992$ \\
\hline & $\begin{array}{l}5-8 \\
9-12\end{array}$ & $\begin{array}{rrrr}-0.1099396 & -0.1346123 & -0.0212798 & 0.0055170 \\
-0.0815594 & 0.1152708 & 0.1344543 & -0.1091606\end{array}$ \\
\hline \multirow{3}{*}{ dlprecsc dlprecsp } & $0-4$ & $0.6077152^{*}-0.046543-0.1207650 .0475923-0.0941611$ \\
\hline & $5-8$ & $-0.1459538:-0.00012440 .07602080 .0820411$ \\
\hline & $9-12$ & 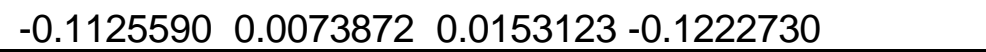 \\
\hline \multirow{3}{*}{ dlprecsp dlprecpr } & $0-4$ & $0.8221221^{*} 0.0401142-0.1282688-0.0003720 .0656548$ \\
\hline & $5-8$ & $-0.1619148-0.08302500 .1076350-0.0303316$ \\
\hline & $9-12$ & $-0.12848600 .11744010 .0132338:-0.1497865$ \\
\hline \multirow{3}{*}{ dlprecpr dlprecsp } & $0-4$ & $0.8221221^{*} 0.2053548^{*}-0.1714180 .005751-0.0191277$ \\
\hline & $5-8$ & $-0.2058628^{\star}-0.02638400 .17142330 .0687530$ \\
\hline & $9-12$ & $-0.1847891^{*} 0.02731090 .0584890-0.2420750^{*}$ \\
\hline \multirow{3}{*}{ dlprecsp dlprecmg } & $0-4$ & $0.6774295^{*} 0.078210-0.0721173-0.058281-0.0132646$ \\
\hline & $5-8$ & $-0.1038574-0.11527760 .0772942-0.0182246$ \\
\hline & $9-12$ & 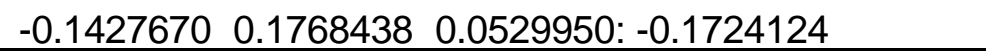 \\
\hline \multirow{3}{*}{ dlprecmg dlprecsp } & $0-4$ & $0.6774295 * 0.0380576-0.0450130 .0623390-0.0823141$ \\
\hline & $5-8$ & $-0.2514089 * 0.05805170 .06270840 .1217334$ \\
\hline & $9-12$ & $-0.0673971-0.0204086-0.0413418-0.1664272$ \\
\hline \multirow{3}{*}{ dlprecsp dlprecgo } & $0-4$ & $\begin{array}{l}0.7651902^{*} 0.04400-0.1578372-0.0155406- \\
0.0444746\end{array}$ \\
\hline & $5-8$ & $-0.1348709-0.08679100 .0944102-0.0786037$ \\
\hline & $9-12$ & 3149 \\
\hline \multirow[b]{2}{*}{ dlprecgo dlprecsp } & $0-4$ & $0.765190^{*} 0.3250418^{*}-0.1348620 .02481150 .0203972$ \\
\hline & $\begin{array}{l}5-8 \\
9-12\end{array}$ & $\begin{array}{rrrrr}-0.1238824 & -0.0829540 & 0.0569508 & 0.0609825 \\
-0.1122363 & 0.0360313 & 0.1670743 & -0.1979408^{*}\end{array}$ \\
\hline \multirow{3}{*}{ dlprecsp dlprecba } & $0-4$ & $0.7447621^{*} 0.269753-0.078850-0.0141736-0.1035440$ \\
\hline & $5-8$ & $-0.0890171-0.1005956-0.00090420 .0863454$ \\
\hline & $9-12$ & $-0.01856150 .0222090-0.0010283:-0.1082101$ \\
\hline \multirow{3}{*}{ dlprecba dlprecsp } & $0-4$ & $0.7447621^{*} 0.0274160-0.1168460 .0466809-0.0837508$ \\
\hline & $5-8$ & $-0.1029073-0.08547270 .0811741-0.05858886$ \\
\hline & $9-12$ & $0.01448250 .0331014-0.0149237-0.1$ \\
\hline \multirow{3}{*}{ dlprecrs dlprecsc } & $0-4$ & $0.5809096^{*} 0.212707^{*}-0.1376515-0.0058140 .1291696$ \\
\hline & $5-8$ & $-0.0289202^{*}-0.0351204 \quad 0.01387710 .0290574$ \\
\hline & & -0 \\
\hline
\end{tabular}


Tabela A12 - Resultados do teste de correlação

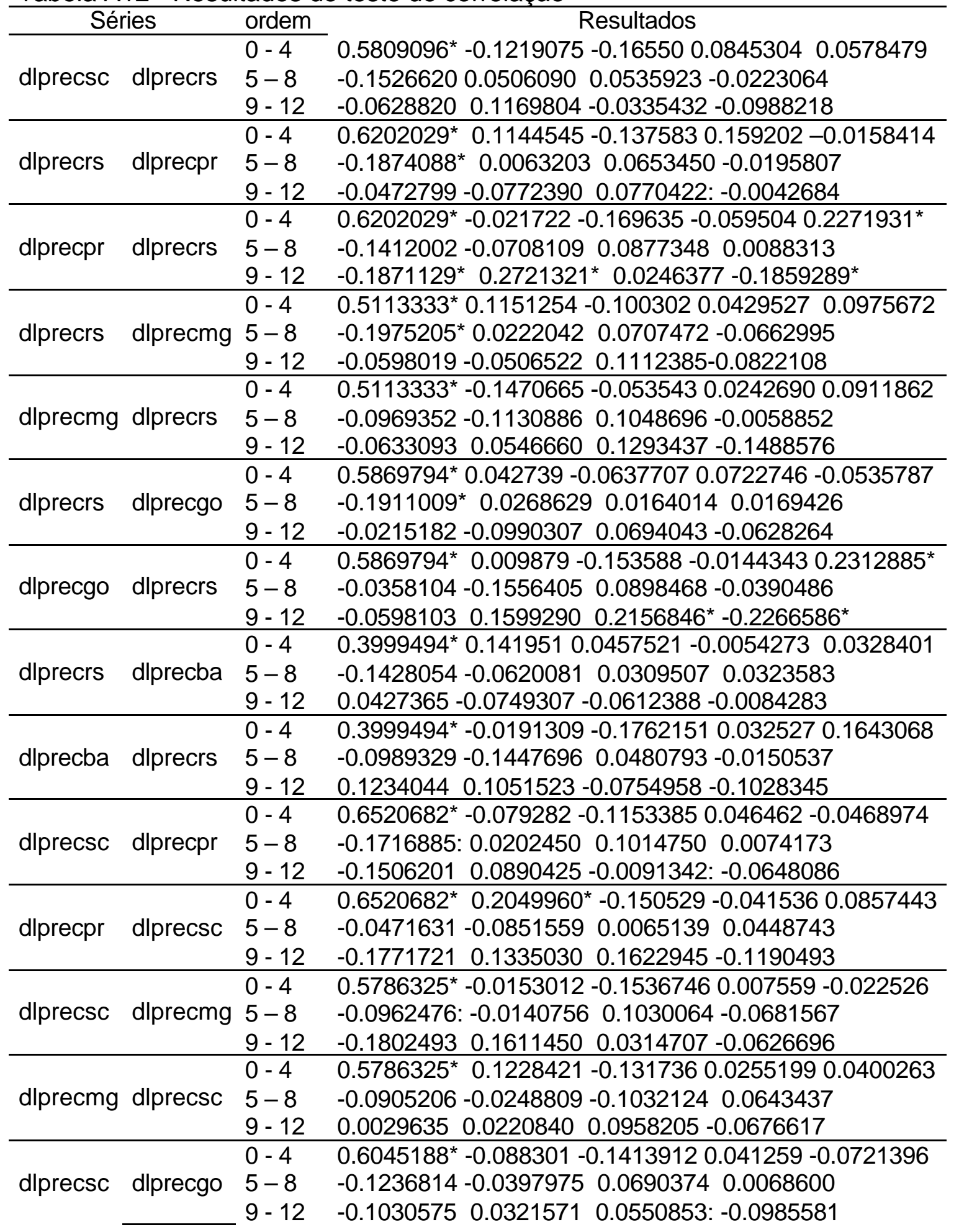


Tabela A12 - Resultados do teste de correlação

\begin{tabular}{|c|c|c|}
\hline Séries & ordem & Resultados \\
\hline \multirow{3}{*}{ dlprecgo dlprecsc } & $0-4$ & $0.6045188^{*} 0.1942615^{*}-0.153517-0.0064840 .1187068$ \\
\hline & $5-8$ & 0.0107072: $-0.1237065-0.09351940 .0718240$ \\
\hline & & $\begin{array}{lll}-0.0959189 & 0.0805699 & 0.2757079^{*}-0.1202475\end{array}$ \\
\hline \multirow{3}{*}{ dlprecsc dlprecba } & $0-4$ & $0.4774745^{*} 0.0602639-0.0603784-0.035887-0.045350$ \\
\hline & $5-8$ & $-0.0743438-0.07562640 .03337240 .0890568$ \\
\hline & $9-12$ & $-0.0658189-0.03220050 .0675651-0.1396697$ \\
\hline \multirow{3}{*}{ dlprecba dlprecsc } & $0-4$ & $0.4774745^{*} 0.130977-0.11495630 .061621-0.0129491$ \\
\hline & $5-8$ & $-0.0335100-0.1561615-0.0228839-0.0110636$ \\
\hline & $9-12$ & $0.0350763 \quad 0.12505150 .0380764:-0.1013591$ \\
\hline \multirow{3}{*}{ dlprecpr } & $0-4$ & $0.6543064^{*} 0.1416738-0.094382-0.064991-0.0242204$ \\
\hline & $5-8$ & $\begin{array}{llll}-0.0806126 & -0.0768535 & 0.0792613 & 0.0652269\end{array}$ \\
\hline & $9-12$ & 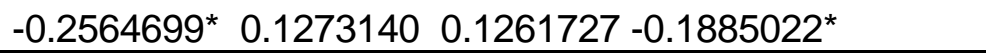 \\
\hline \multirow[b]{2}{*}{ dlprecmg dlprecpr } & $0-4$ & $0.6543064^{*} 0.0034428-0.06716910 .111866-0.0839799$ \\
\hline & $5-8$ & $\begin{array}{lll}-0.1596104:-0.0436600 & 0.0650218 & 0.1030020\end{array}$ \\
\hline \multirow{3}{*}{ dlprecpr dlprecgo } & $\frac{9-12}{0-4}$ & $\frac{-0.129559 / 0.0323165}{0.0065449-0.1294530}$ \\
\hline & $5-8$ & $-0.1315244-0.01133540 .10666790 .0345539$ \\
\hline & $9-12$ & $-0.2391061^{*} 0.1077507-0.0038527-0.1869431^{*}$ \\
\hline \multirow{3}{*}{ dlprecgo dlprecpr } & $0-4$ & $0.7942755^{\star} 0.2020424^{\star}-0.1887586^{*} 0.10713740 .04656$ \\
\hline & $5-8$ & $\begin{array}{llll}-0.0860407 & -0.1333764 & 0.0731929 & 0.0118095\end{array}$ \\
\hline & $9-12$ & 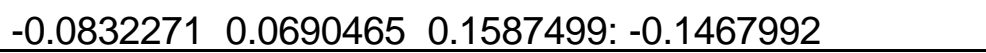 \\
\hline \multirow{3}{*}{ dlprecpr } & $0-4$ & $0.6156527^{*} 0.3465118^{*}-0.104219-0.020669-0.058594$ \\
\hline & $5-8$ & $-0.1311127-0.0063727 \quad 0.01281530 .0739330$ \\
\hline & $9-12$ & $-0.0392560 \quad 0.0053552-0.0$ \\
\hline \multirow{3}{*}{ dlprecba dlprecpr } & $0-4$ & $0.6156527^{*}-0.024425-0.02190590 .0026725-0.025714$ \\
\hline & $5-8$ & $-0.0789972-0.16259730 .0855227-0.0462865$ \\
\hline & $9-12$ & $0.02174690 .0587804-0.0008089:-0.1166664$ \\
\hline \multirow[t]{3}{*}{ dlprecmg dlprecgo } & $0-4$ & $0.6657680^{*}-0.0052623-0.07567900 .014272-0.099262$ \\
\hline & $5-8$ & $\begin{array}{llll}-0.1700800 & -0.0160541 & 0.0694438 & 0.0203587\end{array}$ \\
\hline & $9-12$ & $-0.04701530 .0227200-0.0177115:-0.1956076^{*}$ \\
\hline \multirow{3}{*}{ dlprecgo dlprecmg } & $0-4$ & $0.6657680 * 0.1709424-0.0571592-0.034970-0.000015$ \\
\hline & $5-8$ & $\begin{array}{llll}-0.0276573 & -0.1295131 & 0.0133062 & 0.0363877\end{array}$ \\
\hline & $9-12$ & $-0.15919760 .07791560 .2671807^{\star}:-0.1813727^{*}$ \\
\hline \multirow{3}{*}{ dlprecmg dlprecba } & $0-4$ & $0.5120176 * 0.1679205-0.02071030 .050778-0.0749206$ \\
\hline & $5-8$ & $-0.1893024^{*}:-0.03155630 .00315160 .1408239$ \\
\hline & $9-12$ & $\begin{array}{llll}-0.0564698 & 0.0341649 & 0.0045650 & -0.1953709^{*}\end{array}$ \\
\hline \multirow{3}{*}{ dlprecba } & $0-4$ & $0.5120176 * 0.0988654-0.0455570-0.105513-0.046494$ \\
\hline & $5-8$ & $-0.0400303:-0.14564290 .1029420-0.0681082$ \\
\hline & $9-12$ & $-0.04919820 .1479882-0.0236690-0.1017519$ \\
\hline \multirow{3}{*}{ dlprecgo dlprecba } & $0-4$ & $0.6673187^{*} 0.3425984^{*}-0.0020123-0.015368-0.02601$ \\
\hline & $5-8$ & $\begin{array}{llll}-0.1099515 & -0.0969599 & 0.0098087 & 0.0443041\end{array}$ \\
\hline & $9-12$ & $-0.05241250 .06571760 .0966218:-0.0607837$ \\
\hline
\end{tabular}


Tabela A12 - Resultados do teste de correlação

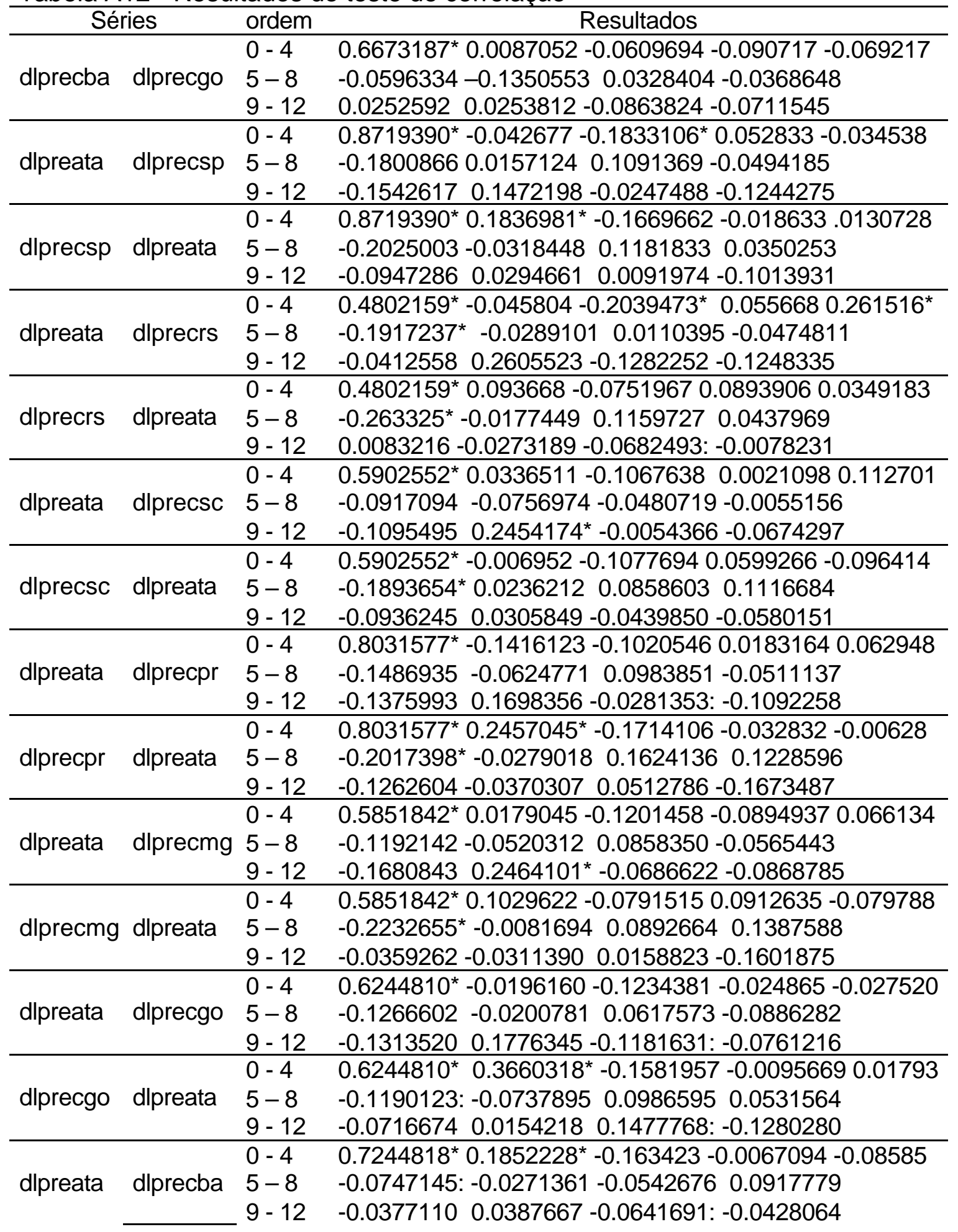


Tabela A12 - Resultados do teste de correlação

\begin{tabular}{|c|c|c|c|}
\hline \multicolumn{2}{|c|}{ Séries } & ordem & Resultados \\
\hline & & $0-4$ & $0.7244818^{*} 0.047672-0.15317810 .0665058-0.066836$ \\
\hline \multirow{2}{*}{ dlprecba } & dlpreata & $5-8$ & $-0.1263225:-0.06306040 .0979051-0.0093593$ \\
\hline & & $9-12$ & $-0.0082210-0.04191350 .0862796:-0.0717346$ \\
\hline & & $0-4$ & $0.8412260 * 0.1721771-0.13813380 .0309930-0.100448$ \\
\hline \multirow{2}{*}{ dlprevar } & dlprecsp & $5-8$ & $\begin{array}{l}-0.1195427-0.04941720 .0722366-0.0390465 \\
\end{array}$ \\
\hline & & $9-12$ & $\begin{array}{l}-0.02709900 .0172091 \quad 0.0106052:-0.1588315 \\
\end{array}$ \\
\hline \multirow{3}{*}{ dlprecsp } & & $0-4$ & $0.8412260 * 0.1178295-0.1669309-0.057438-0.083573$ \\
\hline & dlprevar & $5-8$ & $\begin{array}{llll}0.1201595 & -0.0129433 & 0.0811740 & 0.0249361\end{array}$ \\
\hline & & $9-12$ & $\begin{array}{lll}0.0949576 & 0.0809589 & 0.0010989:-0.1425488\end{array}$ \\
\hline \multirow{3}{*}{ dlprevar } & & $0-4$ & $0.5162742^{*}-0.0367089-0.09738480 .00738340 .161072$ \\
\hline & dlprecrs & $5-8$ & $-0.0787422:-0.0670312-0.0684237-0.0505525$ \\
\hline & & $9-12$ & $0.03910950 .1922655^{*} 0.0360089-0.2274792^{*}$ \\
\hline \multirow{3}{*}{ dlprecrs } & & $0-4$ & $0.5162742^{*} 0.0845104-0.05483350 .0020460 .017622$ \\
\hline & dlprevar & $5-8$ & $\begin{array}{llll}-0.2005605^{*}-0.0305470 & 0.1095871 & 0.0405819\end{array}$ \\
\hline & & $9-12$ & $-0.0144637-0.0805576 \quad 0.0272019-0.0591520$ \\
\hline \multirow{3}{*}{ dlprevar } & & $0-4$ & $0.5739123^{*} 0.1137044-0.08521480 .0418580 .0540599$ \\
\hline & dlprecsc & $5-8$ & $-0.0277097-0.1414155-0.0547462-0.0621761$ \\
\hline & & $9-12$ & $0.00538600 .11239350 .1412522:-0.1638812$ \\
\hline & & $0-4$ & $0.5739123^{*}-0.0285653-0.1191925-0.031580-0.085462$ \\
\hline \multirow[t]{2}{*}{ dlprecsc } & dlprevar & $5-8$ & $\begin{array}{llll}-0.1236312 & 0.0202644 & 0.1023780 & 0.0387748\end{array}$ \\
\hline & & $9-12$ & $\begin{array}{l}-0.09079150 .0296801 \quad 0.0226345:-0.1193793 \\
\end{array}$ \\
\hline \multirow{3}{*}{ dlprevar } & & $0-4$ & $0.7601823^{*} 0.0571985-0.05627330 .0101493-0.048592$ \\
\hline & dlprecpr & $5-8$ & $-0.0418079:-0.13337450 .0411333-0.0341603$ \\
\hline & & $9-12$ & 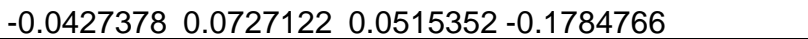 \\
\hline \multirow{3}{*}{ dlprecpr } & & $0-4$ & $0.7601823^{*} 0.1607266-0.1255777-0.074997-0.063022$ \\
\hline & dlprevar & $5-8$ & $-0.1988621^{*} 0.03717660 .13836090 .0882633$ \\
\hline & & $9-12$ & $-0.1836473^{*} 0.05304670 .0519855-0.1934490^{*}$ \\
\hline & & $0-4$ & $0.5997854^{*} 0.0553498-0.068913-0.0393103-0.077295$ \\
\hline \multirow[t]{2}{*}{ dlprevar } & dlprecmg & $5-8$ & $-0.0075210:-0.08068680 .0056416-0.0811359$ \\
\hline & & $9-12$ & $\begin{array}{llll}-0.0095585 & 0.1181532 & 0.0035209 & -0.1596177\end{array}$ \\
\hline \multirow{3}{*}{ dlprecmg } & & $0-4$ & $0.5997854^{*} 0.1317410-0.0763770 .020860-0.2132622^{*}$ \\
\hline & dlprevar & $5-8$ & $\begin{array}{llll}0.1276283 & 0.0588021 & 0.0419355 & 0.1035745\end{array}$ \\
\hline & & $9-12$ & $-0.04444940 .0519991-0.0369341-0.1879227^{*}$ \\
\hline \multirow{3}{*}{ dlprevar } & & $0-4$ & $0.7327547^{*} 0.0853135-0.0748298-0.06249-0.0845729$ \\
\hline & dlprecgo & $5-8$ & $-0.0556841:-0.0965251-0.0105583-0.0305007$ \\
\hline & & $9-12$ & $-0.04075550 .0600225-0.0286059:-0.1080839$ \\
\hline \multirow{3}{*}{ dlprecgo } & & $0-4$ & $0.7327547^{*} 0.2850562^{*}-0.103779-0.074742-0.072195$ \\
\hline & dlprevar & $5-8$ & $\begin{array}{lllll}0.1098901 & -0.0230494 & 0.0461607 & 0.0485536\end{array}$ \\
\hline & & $9-12$ & $\begin{array}{llll}0.0667856 & 0.0656189 & 0.1695919 & -0.1746653 \\
\end{array}$ \\
\hline \multirow{3}{*}{ dlprevar } & & $0-4$ & $0.7157582^{*} 0.2671119^{*}-0.0242120 .0058094-0.146270$ \\
\hline & dlprecba & $5-8$ & $-0.0864879:-0.0413048-0.07248580 .0616332$ \\
\hline & & $9-12$ & $0.00058320 .0164073-0.0143459-0.0606881$ \\
\hline & & $0-4$ & $0.7157582^{*}-0.0152981-0.075848-0.0565006-0.118231$ \\
\hline \multirow[t]{2}{*}{ dlprecba } & dlprevar & $5-8$ & $-0.1295814-0.02735540 .0918684-0.0084232$ \\
\hline & & $9-12$ & $-0.00131020 .0568445-0.0286705:-0.1241704$ \\
\hline \multirow{3}{*}{ dlpreata } & & $0-4$ & $0.7521608^{\star}-0.018103-0.1358117-0.026556-0.0850659$ \\
\hline & dlprevar & $5-8$ & $-0.13766180 .04923470 .0666434-0.0137262$ \\
\hline & & $9-12$ & $-0.12522410 .1395360-0.0316998-0.0802241$ \\
\hline \multirow{3}{*}{ dlprevar } & & $0-4$ & $0.7521608^{*} 0.2203037^{*}-0.1268780 .0022361-0.102794$ \\
\hline & dlpreata & $5-8$ & $\begin{array}{llll}0.1074266 & -0.0378140 & 0.0757199 & 0.0013874\end{array}$ \\
\hline & & $9-12$ & $\begin{array}{llll}-0.0151824 & 0.0021583 & 0.0168142 & -0.1374977\end{array}$ \\
\hline
\end{tabular}


Tabela 13A. Resultados do teste de causalidade.

\begin{tabular}{|c|c|c|c|c|c|}
\hline \multicolumn{2}{|c|}{ Variáveis } & \multicolumn{2}{|c|}{ Testes } & \multirow{2}{*}{$\begin{array}{l}\text { Graus de } \\
\text { Liberdade }\end{array}$} & \multirow{2}{*}{ Resultados } \\
\hline Dependente & independente & $F$ & $\mathrm{Q}$ & & \\
\hline Precsp & Precrs & 1,26 & 0,82 & $(1,113)$ & \\
\hline Precrs & Precsp & 1,87 & 0,13 & $(1,113)$ & Indetermınada \\
\hline Precsp & Precsc & 0,65 & 0,91 & $(1,109)$ & \\
\hline Precsc & Precsp & 0,24 & 0,88 & $(1,113)$ & máeterminada \\
\hline Precsp & Precpr & 3,12 & 0,41 & $(1,113)$ & \\
\hline Precpr & Precsp & $4,96^{\star *}$ & 0,15 & $(1,113)$ & $S R \Rightarrow R R$ \\
\hline Precsp & Precmg & 0,55 & 0,32 & $(1,115)$ & \\
\hline Precmg & Precsp & 0,09 & 0,78 & $(1,113)$ & Indetermınada \\
\hline Precsp & Precgo & 0,56 & 0,39 & $(1,113)$ & \\
\hline Precgo & Precsp & 1,92 & 0,73 & $(1,113)$ & indetermınada \\
\hline Precsp & Precba & 0,99 & 0,84 & $(1,113)$ & \\
\hline Precba & Precsp & 1,76 & 0,86 & $(1,113)$ & Indeterminada \\
\hline Precrs & Precsc & $2,97^{\star * \star}$ & 0,24 & $(1,113)$ & \\
\hline Precsc & Precrs & 2,44 & 0,95 & $(1,113)$ & \\
\hline Precrs & Precpr & $4,38^{* *}$ & 0,09 & $(1,113)$ & \\
\hline Precpr & Precrs & 1,22 & 0,67 & $(1,113)$ & 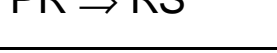 \\
\hline Precrs & Precmg & 2,40 & 0,30 & $(1,113)$ & \\
\hline Precmg & Precrs & $3,00^{* * *}$ & 0,88 & $(1,113)$ & IVIT \\
\hline Precrs & Precgo & 1,41 & 0,22 & $(1,113)$ & \\
\hline Precgo & Precrs & $2,81^{* * *}$ & 0,83 & $(1,113)$ & חऽ $\Rightarrow$ \\
\hline Precrs & Precba & 2,68 & 0,21 & $(1,113)$ & sterminada \\
\hline Precba & Precrs & 0,69 & 0,89 & $(1,113)$ & mine teminnada \\
\hline Precsc & Precpr & 0,83 & 0,91 & $(1,113)$ & arminada \\
\hline Precpr & Precsc & 2,38 & 0,60 & $(1,113)$ & Indeterminada \\
\hline Precsc & Precmg & 0,03 & 0,87 & $(1,113)$ & \\
\hline Precmg & Precsc & 0,62 & 0,91 & $(1,113)$ & Indetermınada \\
\hline Precsc & Precgo & 0,88 & 0,89 & $(1,113)$ & Indeterminada \\
\hline Precgo & Precsc & 0.79 & 0,79 & $(1,113)$ & mátemana \\
\hline Precsc & Precba & 0,25 & 0,86 & $(1,113)$ & Indeterminada \\
\hline Precba & Precsc & 0,17 & 0,97 & $(1,113)$ & mác éminada \\
\hline Precpr & Precmg & 0,37 & 0,32 & $(1,113)$ & Indeterminada \\
\hline Precmg & Precpr & 1,16 & 0,64 & $(1,113)$ & maeterminada \\
\hline Precpr & Precgo & 0,74 & 0,32 & $(1,113)$ & ? \\
\hline Precgo & Precpr & 0,00 & 0,63 & $(1,113)$ & intada \\
\hline Precpr & Precba & $5,66^{* *}$ & 0,65 & $(1,113)$ & $B A \Rightarrow P R$ \\
\hline Precba & Precpr & 3,65 & 0,95 & $(1,113)$ & $\Delta \rightarrow 11$ \\
\hline
\end{tabular}


Tabela A12 - Resultados do teste de correlação

\begin{tabular}{|c|c|c|c|c|c|}
\hline \multicolumn{2}{|c|}{ Variáveis } & \multicolumn{2}{|c|}{ Testes } & \multirow{2}{*}{$\begin{array}{l}\text { Graus de } \\
\text { Liberdade }\end{array}$} & \multirow{2}{*}{ Resultados } \\
\hline Dependente & independente & $\mathrm{F}$ & $Q$ & & \\
\hline Precmg & Precgo & 0,01 & 0,65 & $(1,113)$ & Indeterminada \\
\hline Precgo & Precmg & 0,34 & 0,95 & $(1,113)$ & mácteminada \\
\hline Precmg & Precba & 0,02 & 0,95 & $(1,113)$ & \\
\hline Precba & Precmg & 0,08 & 0,93 & $(1,113)$ & Indeterminada \\
\hline Precgo & Precba & 0,39 & 0,90 & $(1,113)$ & \\
\hline Precba & Precgo & 0,34 & 0,85 & $(1,113)$ & Indetermınada \\
\hline Preata & Precsp & 0,17 & 0,35 & $(1,114)$ & $A T A \rightarrow C P$ \\
\hline Precsp & Preata & $3,72^{* * *}$ & 0,40 & $(1,114)$ & AIA $\Rightarrow$ SI \\
\hline Preata & Precrs & 0,17 & 0,35 & $(1,114)$ & \\
\hline Precrs & Preata & $3,32^{* \star *}$ & 0,24 & $(1,114)$ & $A \mid A \Rightarrow \cap S$ \\
\hline Preata & Precsc & 0,43 & 0,28 & $(1,114)$ & \\
\hline Precsc & Preata & 0,08 & 0,79 & $(1,114)$ & Indeterminada \\
\hline Preata & Precpr & 4,93 & 0,45 & $(1,114)$ & $\Delta T \Delta \rightarrow \mathrm{PR}$ \\
\hline Precpr & Preata & $17,16^{*}$ & 0,63 & $(1,114)$ & माн $\rightarrow \Gamma \Pi$ \\
\hline Preata & Precmg & 0,20 & 0,27 & $(1,114)$ & \\
\hline Precmg & Preata & $4,35^{\star}$ & 0,86 & $(1,114)$ & $A I A \Rightarrow I V I G$ \\
\hline Preata & Precgo & 0,00 & 0,31 & $(1,111)$ & \\
\hline Precgo & Preata & $17,30^{*}$ & 0,84 & $(1,114)$ & $A \mid A \Rightarrow G U$ \\
\hline Preata & Precba & $11,02^{*}$ & 0,30 & $(1,114)$ & \\
\hline Precba & Preata & $8,21^{*}$ & 0,12 & $(1,114)$ & Bıcausal \\
\hline Prevar & Precsp & $4,75^{\star \star}$ & 0,29 & $(1,114)$ & $S P$ \\
\hline Precsp & Prevar & 0,21 & 0,23 & $(1,114)$ & $n$ \\
\hline Prevar & Precrs & 0,93 & 0,63 & $(1,114)$ & \\
\hline Precrs & Prevar & $3,26^{\star \star \star}$ & 0,29 & $(1,114)$ & $V A R \Rightarrow R S$ \\
\hline Prevar & Precsc & 0,83 & 0,43 & $(1,114)$ & Indeterminada \\
\hline Precsc & Prevar & 0,00 & 0,80 & $(1,114)$ & indeterminada \\
\hline Prevar & Precpr & 0,00 & 0,51 & $(1,114)$ & \\
\hline Precpr & Prevar & $5,00^{* *}$ & 0,93 & $(1,114)$ & \\
\hline Prevar & Precmg & 0,01 & 0,50 & $(1,114)$ & \\
\hline Precmg & Prevar & $6,43^{* *}$ & 0,85 & $(1,114)$ & $V A \cap \Rightarrow$ IVIG \\
\hline Prevar & Precgo & 0,20 & 0,41 & $(1,114)$ & $\mathrm{VAR} \Rightarrow \mathrm{GO}$ \\
\hline Precgo & Prevar & $9,22^{*}$ & 0,75 & $(1,114)$ & $v A \cap \Rightarrow G U$ \\
\hline Prevar & Precba & $11,80^{*}$ & 0,74 & $(1,114)$ & \\
\hline Precba & Prevar & 0,41 & 0,74 & $(1,114)$ & DH $\Rightarrow$ VAח \\
\hline Preata & Prevar & 0,00 & 0,30 & $(1,114)$ & $\vec{a}$ \\
\hline Prevar & Preata & $7,50^{*}$ & 0,40 & $(1,114)$ & साA $\rightarrow$ vAn \\
\hline
\end{tabular}


Tabela 14A. Produção anual e percentual das principais microrregiões produtoras de feijão no Brasil no ano de 1990.

\begin{tabular}{|c|c|c|c|c|c|c|c|c|c|}
\hline \multicolumn{10}{|c|}{1990} \\
\hline Ordem & Microrregião & $\begin{array}{c}\text { Produção } \\
(1000 \text { t) }\end{array}$ & $\%$ & $\begin{array}{c}\% \\
\text { acumulado }\end{array}$ & ordem & Microrregião & $\begin{array}{c}\text { Produção } \\
(1000 \text { t) }\end{array}$ & $\%$ & $\begin{array}{c}\% \\
\text { acumulado }\end{array}$ \\
\hline 1 & MR02SC & 81,730 & 3,7 & 3,7 & 26 & MR29PR & 16,419 & 0,7 & 33,8 \\
\hline 2 & MR41SP & 76,862 & 3,5 & 7,2 & 27 & MR04RS & 16,040 & 0,7 & 34,6 \\
\hline 3 & MR09BA & 66,878 & 3,0 & 10,2 & 28 & MR06GO & 15,83 & 0,7 & 35,3 \\
\hline 4 & MR07GO & 36,035 & 1,6 & 11,8 & 29 & MR12GO & 15,574 & 0,7 & 36,0 \\
\hline 5 & MR09SC & 35,932 & 1,6 & 13,4 & 30 & MR01MG & 15,427 & 0,7 & 36,7 \\
\hline 6 & MR18PR & 34,515 & 1,6 & 15,0 & 31 & MR42SP & 14,67 & 0,7 & 37,3 \\
\hline 7 & MR10SC & 32,044 & 1,4 & 16,4 & 32 & MR10MS & 14,585 & 0,7 & 38,0 \\
\hline 8 & MR03RS & 29,879 & 1,3 & 17,8 & 33 & MR15BA & 14,546 & 0,7 & 38,7 \\
\hline 9 & MR06RO & 27,701 & 1,2 & 19,0 & 34 & MR04ES & 14,442 & 0,7 & 39,3 \\
\hline 10 & MR36SP & 23,831 & 1,1 & 20,1 & 35 & MR05SC & 14,028 & 0,6 & 39,9 \\
\hline 11 & MR04RO & 23,604 & 1,1 & 21,2 & 36 & MR10BA & 13,306 & 0,6 & 40,5 \\
\hline 12 & MR06SC & 22,982 & 1,0 & 22,2 & 37 & MR05ES & 13,074 & 0,6 & 41,1 \\
\hline 13 & MR13PR & 22,040 & 1,0 & 23,2 & 38 & MR05PR & 13,026 & 0,6 & 41,7 \\
\hline 14 & MR11PE & 21,711 & 1,0 & 24,2 & 39 & MR06ES & 12,798 & 0,6 & 42,3 \\
\hline 15 & MR02MG & 20,574 & 0,9 & 25,1 & 40 & MR03SC & 12,752 & 0,6 & 42,9 \\
\hline 16 & MR26PR & 19,195 & 0,9 & 26,0 & 41 & MR27BA & 12,674 & 0,6 & 43,4 \\
\hline 17 & MR32PR & 18,743 & 0,8 & 26,8 & 42 & MR16SP & 12,563 & 0,6 & 44,0 \\
\hline 18 & MR44SP & 18,729 & 0,8 & 27,6 & 43 & MR03AL & 12,531 & 0,6 & 44,6 \\
\hline 19 & MR01SC & 18,273 & 0,8 & 28,5 & 44 & MR37PR & 12,400 & 0,6 & 45,1 \\
\hline 20 & MR33PR & 17,550 & 0,8 & 29,3 & 45 & MR08MA & 12,393 & 0,6 & 45,7 \\
\hline 21 & MR20MG & 17,482 & 0,8 & 30,1 & 46 & MR06AL & 12,118 & 0,5 & 46,2 \\
\hline 22 & MR04SC & 17,466 & 0,8 & 30,8 & 47 & MR10SP & 11,84 & 0,5 & 46,8 \\
\hline 23 & MR20RS & 16,940 & 0,8 & 31,6 & 48 & MR18SC & 11,744 & 0,5 & 47,3 \\
\hline 24 & MR31PR & 16,761 & 0,8 & 32,4 & 49 & MR19PR & 11,491 & 0,5 & 47,8 \\
\hline 25 & MR22SP & 16,526 & 0,7 & 33,1 & 50 & MR28BA & 11,421 & 0,5 & 48,3 \\
\hline
\end{tabular}

Fonte: Produção Agrícola Municipal (IBEG, 1990...), adaptados pelo autor. 
Tabela 15A. Produção anual e porcentual das principais microrregiões produtoras de feijão no Brasil no ano de 1991.

\begin{tabular}{|c|c|c|c|c|c|c|c|c|c|}
\hline \multicolumn{10}{|c|}{1991} \\
\hline ordem & Microrregião & $\begin{array}{c}\text { Produção } \\
(1000 \text { t) }\end{array}$ & $\%$ & $\begin{array}{c}\% \% \\
\text { acumulado }\end{array}$ & ordem & Microrregião & $\begin{array}{l}\text { Produção } \\
(1000 \text { t) }\end{array}$ & $\%$ & $\begin{array}{c}\% \\
\text { acumulado }\end{array}$ \\
\hline 1 & MR09BA & 74,397 & 3,4 & 3,4 & 26 & MR03RS & 18,394 & 0,8 & 36,4 \\
\hline 2 & MR41SP & 72,139 & 3,3 & 6,6 & 27 & MR04ES & 18,382 & 0,8 & 37,2 \\
\hline 3 & MR02SC & 55,197 & 2,5 & 9,1 & 28 & MR07PB & 17,609 & 0,8 & 38,0 \\
\hline 4 & MR61SP & 48,000 & 2,2 & 11,3 & 29 & MR32PR & 17,105 & 0,8 & 38,8 \\
\hline 5 & MR18PR & 41,246 & 1,9 & 13,1 & 30 & MR20RS & 16,656 & 0,8 & 39,5 \\
\hline 6 & MR15BA & 39,64 & 1,8 & 14,9 & 31 & MR21PR & 16,520 & 0,7 & 40,3 \\
\hline 7 & MR07GO & 32,004 & 1,4 & 16,4 & 32 & MR04PI & 16,359 & 0,7 & 41,0 \\
\hline 8 & MR18CE & 29,779 & 1,3 & 17,7 & 33 & MR07BA & 16,162 & 0,7 & 41,7 \\
\hline 9 & MR02MG & 28,678 & 1,3 & 19,0 & 34 & MR11PE & 16,134 & 0,7 & 42,5 \\
\hline 10 & MR13PR & 28,433 & 1,3 & 20,3 & 35 & MR14MT & 15,973 & 0,7 & 43,2 \\
\hline 11 & MR10MS & 28,074 & 1,3 & 21,5 & 36 & MR06GO & 15,633 & 0,7 & 43,9 \\
\hline 12 & MR10SP & 27,108 & 1,2 & 22,8 & 37 & MR37PR & 15,236 & 0,7 & 44,6 \\
\hline 13 & MR14BA & 26,187 & 1,2 & 23,9 & 38 & MR04RS & 15,158 & 0,7 & 45,2 \\
\hline 14 & MR23CE & 23,941 & 1,1 & 25,0 & 39 & MR14PI & 15,054 & 0,7 & 45,9 \\
\hline 15 & MR01BA & 23,118 & 1,0 & 26,1 & 40 & MR08BA & 15,051 & 0,7 & 46,6 \\
\hline 16 & MR26PR & 22,681 & 1,0 & 27,1 & 41 & MR22SP & 15,035 & 0,7 & 47,3 \\
\hline 17 & MR01MG & 22,405 & 1,0 & 28,1 & 42 & MR08MA & 14,780 & 0,7 & 47,9 \\
\hline 18 & MR06SC & 22,036 & 1,0 & 29,1 & 43 & MR07MG & 14,611 & 0,7 & 48,6 \\
\hline 19 & MR15PI & 21,597 & 1,0 & 30,1 & 44 & MR12GO & 14,593 & 0,7 & 49,3 \\
\hline 20 & MR29PR & 21,067 & 1,0 & 31,0 & 45 & MR20PR & 14,325 & 0,6 & 49,9 \\
\hline 21 & MR14RN & 20,967 & 0,9 & 32,0 & 46 & MR05SC & 14,290 & 0,6 & 50,6 \\
\hline 22 & MR31PR & 20,927 & 0,9 & 32,9 & 47 & MR01PE & 14,122 & 0,6 & 51,2 \\
\hline 23 & MR36SP & 20,014 & 0,9 & 33,8 & 48 & MR03AL & 14,111 & 0,6 & 51,8 \\
\hline 24 & MR44SP & 19,656 & 0,9 & 34,7 & 49 & MR01SC & 13,839 & 0,6 & 52,5 \\
\hline 25 & MR19PR & 18,590 & 0,8 & 35,5 & 50 & MR42SP & 13,422 & 0,6 & 53,1 \\
\hline
\end{tabular}

Fonte: Produção Agrícola Municipal (IBEG, 1990...), adaptados pelo autor. 
Tabela 16A. Produção anual e porcentual das principais microrregiões produtoras de feijão no Brasil no ano de 1992.

\begin{tabular}{|c|c|c|c|c|c|c|c|c|c|}
\hline \multicolumn{10}{|c|}{1992} \\
\hline Ordem & Microrregião & $\begin{array}{c}\text { Produção } \\
(1000 \text { t) }\end{array}$ & $\%$ & $\begin{array}{c}\% \% \\
\text { acumulado }\end{array}$ & ordem & Microrregião & $\begin{array}{l}\text { Produção } \\
(1000 \text { t) }\end{array}$ & $\%$ & $\begin{array}{c}\% \% \\
\text { acumulado }\end{array}$ \\
\hline 1 & MR09BA & 221,55 & 10,0 & 10,0 & 26 & MR04SC & 23,477 & 1,1 & 52,2 \\
\hline 2 & MR02SC & 118,983 & 5,4 & 15,4 & 27 & MR01MG & 22,692 & 1,0 & 53,3 \\
\hline 3 & MR41SP & 85,21 & 3,8 & 19,2 & 28 & MR19PR & 21,565 & 1,0 & 54,2 \\
\hline 4 & MR26PR & 51,185 & 2,3 & 21,5 & 29 & MR33PR & 20,402 & 0,9 & 55,2 \\
\hline 5 & MR03RS & 46,942 & 2,1 & 23,6 & 30 & MR36PR & 20,083 & 0,9 & 56,1 \\
\hline 6 & MR09SC & 43,360 & 2,0 & 25,6 & 31 & MR04RO & 19,663 & 0,9 & 56,9 \\
\hline 7 & MR10SC & 36,245 & 1,6 & 27,2 & 32 & MR37PR & 18,893 & 0,9 & 57,8 \\
\hline 8 & MR01BA & 35,051 & 1,6 & 28,8 & 33 & MR22SP & 18,83 & 0,8 & 58,6 \\
\hline 9 & MR07GO & 34,918 & 1,6 & 30,4 & 34 & MR10SP & 18,206 & 0,8 & 59,5 \\
\hline 10 & MR10BA & 34,882 & 1,6 & 31,9 & 35 & MR05RS & 16,909 & 0,8 & 60,2 \\
\hline 11 & MR32PR & 34,553 & 1,6 & 33,5 & 36 & MR14RN & 16,382 & 0,7 & 61,0 \\
\hline 12 & MR31PR & 34,265 & 1,5 & 35,1 & 37 & MR07PB & 16,377 & 0,7 & 61,7 \\
\hline 13 & MR29PR & 31,856 & 1,4 & 36,5 & 38 & MR23CE & 16,218 & 0,7 & 62,4 \\
\hline 14 & MR06SC & 31,662 & 1,4 & 37,9 & 39 & MR06GO & 16,05 & 0,7 & 63,2 \\
\hline 15 & MR18PR & 31,020 & 1,4 & 39,3 & 40 & MR15BA & 15,809 & 0,7 & 63,9 \\
\hline 16 & MR36SP & 29,322 & 1,3 & 40,6 & 41 & MR27PR & 15,375 & 0,7 & 64,6 \\
\hline 17 & MR13PR & 29,189 & 1,3 & 42,0 & 42 & MR44SP & 14,708 & 0,7 & 65,2 \\
\hline 18 & MR06RO & 27,972 & 1,3 & 43,2 & 43 & MR16SP & 14,492 & 0,7 & 65,9 \\
\hline 19 & MR04RS & 27,684 & 1,2 & 44,5 & 44 & MR04ES & 14,314 & 0,6 & 66,5 \\
\hline 20 & MR02MG & 26,714 & 1,2 & 45,7 & 45 & MR25PR & 14,245 & 0,6 & 67,2 \\
\hline 21 & MR21PR & 24,890 & 1,1 & 46,8 & 46 & MR28PR & 14,092 & 0,6 & 67,8 \\
\hline 22 & MR01SC & 24,857 & 1,1 & 47,9 & 47 & MR42SP & 13,647 & 0,6 & 68,4 \\
\hline 23 & MR03SC & 24,724 & 1,1 & 49,0 & 48 & MR03BA & 13,42 & 0,6 & 69,0 \\
\hline 24 & MR05SC & 24,047 & 1,1 & 50,1 & 49 & MR03MG & 12,136 & 0,5 & 69,6 \\
\hline 25 & MR08BA & 23,689 & 1,1 & 51,2 & 50 & MR34PR & 12,116 & 0,5 & 70,1 \\
\hline
\end{tabular}

Fonte: Produção Agrícola Municipal (IBEG, 1990...), adaptados pelo autor. 
Tabela 17A. Produção anual e porcentual das principais microrregiões produtoras de feijão no Brasil no ano de 1993.

\begin{tabular}{|c|c|c|c|c|c|c|c|c|c|}
\hline \multicolumn{10}{|c|}{1993} \\
\hline Ordem & Microrregião & $\begin{array}{c}\text { Produção } \\
(1000 \text { t) }\end{array}$ & $\%$ & $\begin{array}{c}\% \% \\
\text { acumulado }\end{array}$ & ordem & Microrregião & $\begin{array}{c}\text { Produção } \\
(1000 \text { t) }\end{array}$ & $\%$ & $\begin{array}{c}\% \% \\
\text { acumulado }\end{array}$ \\
\hline 1 & MR09BA & 112,522 & 5,1 & 5,1 & 26 & MR07BA & 21,02 & 0,9 & 45,4 \\
\hline 2 & MR02SC & 88,694 & 4,0 & 9,1 & 27 & MR19PR & 20,917 & 0,9 & 46,4 \\
\hline 3 & MR41SP & 82,308 & 3,7 & 12,8 & 28 & MR33PR & 19,263 & 0,9 & 47,2 \\
\hline 4 & MR01BA & 49,57 & 2,2 & 15,0 & 29 & MR03SC & 19,123 & 0,9 & 48,1 \\
\hline 5 & MR26PR & 44,928 & 2,0 & 17,0 & 30 & MR05SC & 18,692 & 0,8 & 49,0 \\
\hline 6 & MR03BA & 38,693 & 1,7 & 18,8 & 31 & MR04SC & 18,662 & 0,8 & 49,8 \\
\hline 7 & MR29PR & 38,000 & 1,7 & 20,5 & 32 & MR26BA & 18,013 & 0,8 & 50,6 \\
\hline 8 & MR32PR & 36,665 & 1,7 & 22,2 & 33 & MR20MG & 17,651 & 0,8 & 51,4 \\
\hline 9 & MR01MG & 34,407 & 1,6 & 23,7 & 34 & MR16SP & 17,264 & 0,8 & 52,2 \\
\hline 10 & MR02MG & 33,887 & 1,5 & 25,2 & 35 & MR44SP & 16,994 & 0,8 & 53,0 \\
\hline 11 & MR31PR & 33,378 & 1,5 & 26,7 & 36 & MR25PR & 16,612 & 0,7 & 53,7 \\
\hline 12 & MR06SC & 33,299 & 1,5 & 28,2 & 37 & MR07ES & 16,553 & 0,7 & 54,4 \\
\hline 13 & MR13PR & 33,018 & 1,5 & 29,7 & 38 & MR12GO & 16,531 & 0,7 & 55,2 \\
\hline 14 & MR09SC & 32,809 & 1,5 & 31,2 & 39 & MR34PR & 16,116 & 0,7 & 55,9 \\
\hline 15 & MR03RS & 31,816 & 1,4 & 32,7 & 40 & MR42SP & 15,877 & 0,7 & 56,6 \\
\hline 16 & MR06RO & 30,450 & 1,4 & 34,0 & 41 & MR49MG & 15,393 & 0,7 & 57,3 \\
\hline 17 & MR18PR & 29,727 & 1,3 & 35,4 & 42 & MR36PR & 15,289 & 0,7 & 58,0 \\
\hline 18 & MR04RO & 28,769 & 1,3 & 36,7 & 43 & MR20PR & 14,945 & 0,7 & 58,7 \\
\hline 19 & MR36SP & 27,618 & 1,2 & 37,9 & 44 & MR23PR & 14,819 & 0,7 & 59,4 \\
\hline 20 & MR10SC & 27,530 & 1,2 & 39,2 & 45 & MR07MG & 14,651 & 0,7 & 60,0 \\
\hline 21 & MR07GO & 27,069 & 1,2 & 40,4 & 46 & MR10BA & 14,263 & 0,6 & 60,7 \\
\hline 22 & MR04RS & 23,486 & 1,1 & 41,4 & 47 & MR10SP & 14,173 & 0,6 & 61,3 \\
\hline 23 & MR21PR & 23,002 & 1,0 & 42,5 & 48 & MR05RS & 13,874 & 0,6 & 61,9 \\
\hline 24 & MR22SP & 22,828 & 1,0 & 43,5 & 49 & MR27PR & 13,709 & 0,6 & 62,5 \\
\hline 25 & MR37PR & 21,932 & 1,0 & 44,5 & 50 & MR10MS & 13,354 & 0,6 & 63,2 \\
\hline
\end{tabular}

Fonte: Produção Agrícola Municipal (IBEG, 1990...), adaptados pelo autor. 
Tabela 18A. Produção anual e porcentual das principais microrregiões produtoras de feijão no Brasil no ano de 1994.

\begin{tabular}{|c|c|c|c|c|c|c|c|c|c|}
\hline \multicolumn{10}{|c|}{1994} \\
\hline ordem & Microrregião & $\begin{array}{c}\text { Produção } \\
(1000 \text { t) }\end{array}$ & $\%$ & $\begin{array}{c}\% \% \\
\text { acumulado }\end{array}$ & ordem & Microrregião & $\begin{array}{l}\text { Produção } \\
(1000 \text { t) }\end{array}$ & $\%$ & $\begin{array}{c}\% \\
\text { acumulado }\end{array}$ \\
\hline 1 & MR02SC & 122,533 & 5,5 & 5,5 & 26 & MR03MG & 25,406 & 1,1 & 46,3 \\
\hline 2 & MR41SP & 78,111 & 3,5 & 9,0 & 27 & MR11PE & 25,126 & 1,1 & 47,5 \\
\hline 3 & MR26PR & 52,322 & 2,4 & 11,4 & 28 & MR01PE & 24,663 & 1,1 & 48,6 \\
\hline 4 & MR01MG & 50,5 & 2,3 & 13,7 & 29 & MR15PI & 24,413 & 1,1 & 49,7 \\
\hline 5 & MR31PR & 44,555 & 2,0 & 15,7 & 30 & MR03BA & 24,289 & 1,1 & 50,8 \\
\hline 6 & MR03RS & 43,060 & 1,9 & 17,6 & 31 & MR25PR & 23,880 & 1,1 & 51,8 \\
\hline 7 & MR06SC & 42,050 & 1,9 & 19,5 & 32 & MR04RS & 23,633 & 1,1 & 52,9 \\
\hline 8 & MR32PR & 41,816 & 1,9 & 21,4 & 33 & MR14RN & 23,626 & 1,1 & 54,0 \\
\hline 9 & MR01BA & 41,76 & 1,9 & 23,3 & 34 & MR03AL & 23,446 & 1,1 & 55,0 \\
\hline 10 & MR02MG & 35,078 & 1,6 & 24,9 & 35 & MR03SC & 23,290 & 1,1 & 56,1 \\
\hline 11 & MR13PR & 34,758 & 1,6 & 26,5 & 36 & MR33PR & 23,110 & 1,0 & 57,1 \\
\hline 12 & MR23CE & 33,654 & 1,5 & 28,0 & 37 & MR04PI & 22,715 & 1,0 & 58,2 \\
\hline 13 & MR18CE & 33,560 & 1,5 & 29,5 & 38 & MR04SC & 22,307 & 1,0 & 59,2 \\
\hline 14 & MR09SC & 32,456 & 1,5 & 30,9 & 39 & MR37PR & 21,864 & 1,0 & 60,1 \\
\hline 15 & MR15BA & 31,72 & 1,4 & 32,4 & 40 & MR05SC & 21,827 & 1,0 & 61,1 \\
\hline 16 & MR03PE & 31,607 & 1,4 & 33,8 & 41 & MR36PR & 21,210 & 1,0 & 62,1 \\
\hline 17 & MR06RO & 30,616 & 1,4 & 35,2 & 42 & MR01SE & 20,997 & 0,9 & 63,0 \\
\hline 18 & MR29PR & 30,579 & 1,4 & 36,6 & 43 & MR34PR & 20,477 & 0,9 & 64,0 \\
\hline 19 & MR07GO & 29,769 & 1,3 & 37,9 & 44 & MR12GO & 20,374 & 0,9 & 64,9 \\
\hline 20 & MR18PR & 28,082 & 1,3 & 39,2 & 45 & MR09BA & 20,008 & 0,9 & 65,8 \\
\hline 21 & MR19PR & 27,604 & 1,2 & 40,4 & 46 & MR07BA & 19,686 & 0,9 & 66,7 \\
\hline 22 & MR36SP & 27,154 & 1,2 & 41,6 & 47 & MR19CE & 19,581 & 0,9 & 67,6 \\
\hline 23 & MR04RO & 26,800 & 1,2 & 42,9 & 48 & MR21CE & 19,205 & 0,9 & 68,4 \\
\hline 24 & MR21PR & 26,190 & 1,2 & 44,0 & 49 & MR42SP & 18,489 & 0,8 & 69,3 \\
\hline 25 & MR10SC & 25,457 & 1,1 & 45,2 & 50 & MR08RO & 18,401 & 0,8 & 70,1 \\
\hline
\end{tabular}

Fonte: Produção Agrícola Municipal (IBEG, 1990...), adaptados pelo autor. 
Tabela 19A. Produção anual e porcentual das principais microrregiões produtoras de feijão no Brasil no ano de 1995.

\begin{tabular}{|c|c|c|c|c|c|c|c|c|c|}
\hline \multicolumn{10}{|c|}{1995} \\
\hline Ordem & Microrregião & $\begin{array}{c}\text { Produção } \\
(1000 \text { t) }\end{array}$ & $\%$ & $\begin{array}{c}\% \\
\text { acumulado }\end{array}$ & Ordem & Microrregião & $\begin{array}{l}\text { Produção } \\
\text { (1000 t) }\end{array}$ & $\%$ & $\begin{array}{c}\% \\
\text { acumulado }\end{array}$ \\
\hline 1 & MR02SC & 120,568 & 5,4 & 5,4 & 26 & MR07BA & 21,475 & 1,0 & 42,9 \\
\hline 2 & MR26PR & 74,694 & 3,4 & 8,8 & 27 & MR04SC & 21,448 & 1,0 & 43,9 \\
\hline 3 & MR41SP & 66,213 & 3,0 & 11,8 & 28 & MR23CE & 21,407 & 1,0 & 44,8 \\
\hline 4 & MR01MG & 47,263 & 2,1 & 13,9 & 29 & MR03MG & 20,981 & 0,9 & 45,8 \\
\hline 5 & MR03RS & 42,318 & 1,9 & 15,8 & 30 & MR05RS & 20,749 & 0,9 & 46,7 \\
\hline 6 & MR25PR & 41,570 & 1,9 & 17,7 & 31 & MR20RS & 20,333 & 0,9 & 47,6 \\
\hline 7 & MR09SC & 40,012 & 1,8 & 19,5 & 32 & MR21CE & 19,991 & 0,9 & 48,5 \\
\hline 8 & MR31PR & 39,459 & 1,8 & 21,3 & 33 & MR15PI & 19,569 & 0,9 & 49,4 \\
\hline 9 & MR15BA & 37,488 & 1,7 & 23,0 & 34 & MR14RN & 19,243 & 0,9 & 50,3 \\
\hline 10 & MR21PR & 31,430 & 1,4 & 24,4 & 35 & MR15GO & 19,221 & 0,9 & 51,1 \\
\hline 11 & MR04RO & 30,237 & 1,4 & 25,8 & 36 & MR01PE & 18,752 & 0,8 & 52,0 \\
\hline 12 & MR11PE & 29,721 & 1,3 & 27,1 & 37 & MR05SC & 18,688 & 0,8 & 52,8 \\
\hline 13 & MR32PR & 28,655 & 1,3 & 28,4 & 38 & MR03PE & 18,409 & 0,8 & 53,7 \\
\hline 14 & MR23PR & 28,424 & 1,3 & 29,7 & 39 & MR01SC & 17,981 & 0,8 & 54,5 \\
\hline 15 & MR06RO & 27,279 & 1,2 & 30,9 & 40 & MR19PR & 17,964 & 0,8 & 55,3 \\
\hline 16 & MR02MG & 27,165 & 1,2 & 32,1 & 41 & MR14BA & 17,406 & 0,8 & 56,1 \\
\hline 17 & MR07GO & 27,087 & 1,2 & 33,4 & 42 & MR07PB & 17,25 & 0,8 & 56,8 \\
\hline 18 & MR04RS & 26,951 & 1,2 & 34,6 & 43 & MR13BA & 16,294 & 0,7 & 57,6 \\
\hline 19 & MR10SC & 25,077 & 1,1 & 35,7 & 44 & MR06SC & 16,111 & 0,7 & 58,3 \\
\hline 20 & MR03AL & 24,229 & 1,1 & 36,8 & 45 & MR18PR & 16,039 & 0,7 & 59,0 \\
\hline 21 & MR03SC & 23,822 & 1,1 & 37,9 & 46 & MR13PR & 15,982 & 0,7 & 59,7 \\
\hline 22 & MR01BA & 23,37 & 1,1 & 38,9 & 47 & MR20PR & 15,246 & 0,7 & 60,4 \\
\hline 23 & MR03BA & 22,967 & 1,0 & 40,0 & 48 & MR10SP & 15,135 & 0,7 & 61,1 \\
\hline 24 & MR01SE & 21,772 & 1,0 & 40,9 & 49 & MR42SP & 14,822 & 0,7 & 61,8 \\
\hline 25 & MR12GO & 21,564 & 1,0 & 41,9 & 50 & MR33CE & 14,807 & 0,7 & 62,5 \\
\hline
\end{tabular}

Fonte: Produção Agrícola Municipal (IBEG, 1990...), adaptados pelo autor. 
Tabela 20A. Produção anual e porcentual das principais microrregiões produtoras de feijão no Brasil no ano de 1996.

\begin{tabular}{|c|c|c|c|c|c|c|c|c|c|}
\hline \multicolumn{10}{|c|}{1996} \\
\hline Ordem & Microrregião & $\begin{array}{c}\text { Produção } \\
(1000 \text { t) }\end{array}$ & $\%$ & $\begin{array}{c}\% \\
\text { acumulado }\end{array}$ & Ordem & Microrregião & $\begin{array}{c}\text { Produção } \\
(1000 \text { t) }\end{array}$ & $\%$ & $\begin{array}{c}\% \\
\text { acumulado }\end{array}$ \\
\hline 1 & MR02SC & 65,873 & 3,0 & 3,0 & 26 & MR10SC & 19,746 & 0,9 & 39,5 \\
\hline 2 & MR41SP & 55,4 & 2,5 & 5,5 & 27 & MR01PE & 19,229 & 0,9 & 40,3 \\
\hline 3 & MR31PR & 46,848 & 2,1 & 7,6 & 28 & MR34PR & 19,141 & 0,9 & 41,2 \\
\hline 4 & MR32PR & 44,118 & 2,0 & 9,6 & 29 & MR33PR & 18,336 & 0,8 & 42,0 \\
\hline 5 & MR26PR & 44,038 & 2,0 & 11,6 & 30 & MR28PR & 17,918 & 0,8 & 42,8 \\
\hline 6 & MR21PR & 41,131 & 1,9 & 13,4 & 31 & MR04RS & 17,783 & 0,8 & 43,6 \\
\hline 7 & MR09BA & 39,368 & 1,8 & 15,2 & 32 & MR31CE & 17,771 & 0,8 & 44,4 \\
\hline 8 & MR14BA & 38,155 & 1,7 & 16,9 & 33 & MR18PR & 17,616 & 0,8 & 45,2 \\
\hline 9 & MR15BA & 36,727 & 1,7 & 18,6 & 34 & MR25PR & 17,411 & 0,8 & 46,0 \\
\hline 10 & MR09SC & 36,644 & 1,7 & 20,2 & 35 & MR04SC & 17,021 & 0,8 & 46,8 \\
\hline 11 & MR03AL & 36,456 & 1,6 & 21,9 & 36 & MR03PE & 16,707 & 0,8 & 47,5 \\
\hline 12 & MR06RO & 33,682 & 1,5 & 23,4 & 37 & MR42SP & 16,504 & 0,7 & 48,3 \\
\hline 13 & MR19PR & 32,910 & 1,5 & 24,9 & 38 & MR22SP & 16,126 & 0,7 & 49,0 \\
\hline 14 & MR01MG & 32,146 & 1,4 & 26,3 & 39 & MR12BA & 15,988 & 0,7 & 49,7 \\
\hline 15 & MR01BA & 31,57 & 1,4 & 27,7 & 40 & MR14RN & 15,260 & 0,7 & 50,4 \\
\hline 16 & MR13PR & 28,327 & 1,3 & 29,0 & 41 & MR01SE & 15,144 & 0,7 & 51,1 \\
\hline 17 & MR29PR & 27,206 & 1,2 & 30,2 & 42 & MR01SC & 14,608 & 0,7 & 51,7 \\
\hline 18 & MR11PE & 26,273 & 1,2 & 31,4 & 43 & MR23CE & 14,563 & 0,7 & 52,4 \\
\hline 19 & MR01AL & 25,95 & 1,2 & 32,6 & 44 & MR02GO & 14,412 & 0,7 & 53,1 \\
\hline 20 & MR03RS & 24,790 & 1,1 & 33,7 & 45 & MR18CE & 14,062 & 0,6 & 53,7 \\
\hline 21 & MR06SC & 22,931 & 1,0 & 34,8 & 46 & MR15PI & 13,947 & 0,6 & 54,3 \\
\hline 22 & MR03BA & 22,023 & 1,0 & 35,7 & 47 & MR36PR & 13,942 & 0,6 & 54,9 \\
\hline 23 & MR23PR & 21,105 & 1,0 & 36,7 & 48 & MR02PE & 13,884 & 0,6 & 55,6 \\
\hline 24 & MR37PR & 20,851 & 0,9 & 37,6 & 49 & MR07BA & 13,771 & 0,6 & 56,2 \\
\hline 25 & MR06AL & 20,477 & 0,9 & 38,6 & 50 & MR12GO & 13,732 & 0,6 & 56,8 \\
\hline
\end{tabular}

Fonte: Produção Agrícola Municipal (IBEG, 1990...), adaptados pelo autor. 